\title{
CERVANTES Y AVELLANEDA ESTUDIO DE UNA IMITACIÓN
}

\author{
por \\ Stephen Gilman
}

NUEVA REVISTA DE EL COLEGIO DE MÉXICO 
PUBLICACIONES DE LA

\section{NUEVA REVISTA DE FILOLOGÍA HISPÁNICA}

II 


\title{
CERVANTES Y AVELLANEDA \\ ESTUDIO DE UNA IMITACIÓN
}

\author{
por \\ Stephen Gilman
}

\author{
prólogo de \\ Américo Castro
}

NUEVA REVISTA DE FILOLOGÍA HISPÁNICA

\section{EL COLEGIO DE MÉXICO}


Gilman, Stephen.

Cervantes y Avellaneda. Estudio de una imitación / prólogo de Américo Castro / traducción del original inédito por Margit Frenk. -- Versión digital. -- Ciudad de México: El Colegio de México, Nueva Revista de Filología Hispánica, 2018.

170 pp. (Publicaciones de la NRFH, 2).

ISBN 978-607-628-374-5

Cuidado de la versión digital:

Jorge Valenzuela y Pedro Martín Butragueño

Diseño y maquetación: Alejandro Rivas

Colaboración de Perla Muñoz y Adriana Nieves

Versión digital basada en la primera edición de 1951.

Traducción del original inÉdito por Margit Frenk Alatorre

D.R. C 1951 El Colegio de México

D.R. C2018 El Colegio de México

Carretera Picacho Ajusco núm. 20

Col. Ampliación Fuentes del Pedregal

Tlalpan 14110, Ciudad de México

nrfh@colmex.mx

ISBN 978-607-628-374-5

Hecho en México 


\section{PRÓLOGO}

Es muy grata tarea escribir unas páginas iniciales para el primer libro del profesor Stephen Gilman, una muy alta esperanza con que cuenta el hispanismo, no sólo en los Estados Unidos, sino en donde quiera que exista interés por el modo en que los hispanos han expresado su vida. Al decir esperanza no pienso en voluminosos libros, intrincadas investigaciones o rastreo de ideas; me refiero más bien a la percepción de lo que en el arte literario haya de viva realidad para nosotros, de realidad valiosa y estéticamente captable.

Las páginas que siguen sobre el Quijote de Avellaneda me parecen excelentes, pues ponen de relieve algo hasta ahora no visto, el cómo de la obra, su auténtico "avellanedismo". Los eruditos se habían preocupado, ante todo, de descifrar el curioso enigma de quién hubiese sido la persona mortal encubierta bajo el nombre del licenciado Alonso Fernández de Avellaneda; y viene siendo lugar común calcular, grosso modo, la distancia, en cuanto a calidad artística, entre el libro de Cervantes y el de su mezquino imitador. Tomando ahora otro rumbo, Gilman va a poner de manifiesto la verdad vital del Quijote intruso, cómo se realiza en él una voluntad de creación novelesca, la posible para un Avellaneda, situado entre 1605 y 1614 en la España de Felipe III. Se ponen de manifiesto ahora los motivos vitales y las metas humanas que convirtieron aquel desmandado intento en actividad justificada - justificada para quienes, como el "desamorado" Avellaneda, contemplara el Quijote de 
Cervantes desde un cierto punto de estimación, y sintiéndose íntimamente muy desazonado. Aquel audaz adivinó los pensamientos del eclesiástico insultador de don Quijote en casa de los Duques, y puso bien de manifiesto cuán a contrapelo de las preferencias literarias de su tiempo había escrito Cervantes.

Avellaneda es un punto en la línea que va del Guzmán de Alfarache, de Mateo Alemán (1599), a El Criticón de Baltasar Gracián (1658): este último prefería la prosa del desesperado pícaro a la humanamente firme de Cervantes. Tales obras, El Diablo Cojuelo de Luis Vélez de Guevara y otras no menos significativas, son como voceros de la situación de vida que cerraba el paso a la magna y auténtica posibilidad novelística lanzada por Cervantes a los vientos de la historia europea. El éxito logrado por el Quijote, es decir, la seducción que ejercía sobre propios y extraños, no implicaba en modo alguno capacidad en los lectores de convertir aquel poderoso manantial de expresión humana en un cauce continuable: la contemplación de la maravilla cervantina, explicada y sumergida en sí misma, no dio lugar a acciones en que la forma latente en el Quijote fuese recreada. Y tomando un punto de vista inverso, el silencio y la desatención en torno al intruso Quijote no significan que el tal Avellaneda no representara auténticamente la manera de estar en la vida de quienes en España tenían la posibilidad de tomar la pluma. Para ser portavoz del sentir común de las gentes no es indispensable poseer genialidad. El Intruso se erguía como un dómine altanero, justamente por sentirse apoyado por los más; entonces como siempre, el poca cosa infla su conciencia de existir apenas, con la temblona convicción de ser punta visible del inexpresado sentir de los más. Se confunde así la importancia de un estado de ánimo colectivo, con una valiosa y durable trascendencia, pues la necesidad de proteger el propio existir y el subsistir, por capi- 
talísimo que sea, no constituye en sí misma nada valioso, digno de subsistir como forma maravillosa de algo.

El Quijote intruso valió como tajante advertencia - hecha en tono cascado, acre y petulante - de que no se toleraría el intento de "quilatar con su estimación las cosas", ni decir "la cosa" y comentarla "como viene a cuento a cada uno" (Guzmán de Alfarache). Prevalecía la creencia de no ser menester lícito hacer existir a una persona, o a un personaje, forjándose su vida según a cada cual conviene y mediante un sistema de propias estimaciones. Entonces, la vía señalada por Cervantes se hizo callejón sin salida. A los españoles se les terminaba el estímulo vital, y el heroísmo y el amor cesaron de trazar deslumbrantes horizontes. En El Diablo Cojuelo aparece un "templo sin altar, y en medio de él, una pila grande de piedra llena de libros de caballerías y novelas, y alrededor muchos muchachos de diez a diez y siete años y algunas doncelluelas de la misma edad, y cada uno y cada una con su padrino al lado. Ésta es, don Cleofás, en efecto, la pila de los dones, y aquí se bautizan los que vienen a la corte sin él". Del libro de caballerías sobrevive tan sólo el rumor de sus nombres. Poco antes de morir escribía Quevedo: "Pocas cosas pueden ser ya prodigio... Esto [esto es España] ni sé si se va acabando, ni si se acabó. Dios lo sabe; que hay muchas cosas que, pareciendo que existen y tienen ser, ya no son nada sino un vocablo y una figura". Para Gracián, el mundo se cifra en la "Cueva de la nada". En un mundo así concebido, sin cimientos y sin perspectivas, construcciones vitales como las de don Quijote, Sancho o Sansón Carrasco nada tenían que hacer. Sin proyecto de tarea, el vivir hacia adelante, apoyándose en sí mismo, en que consiste ser personaje de novela, carece de la posibilidad de realizarse. Fuera de España, por diferentes motivos, la especial forma de literatura iniciada 
por Cervantes tampoco podía prosperar. No ciertamente en la Italia escéptica, irónica y espectacular del seiscientos. Ni en la Francia del filosófico razonar en donde la vida del hombre era un tema de quietos análisis cognoscitivos - "l'analyse psychologique" - , y no posibilidad para el lanzamiento de una existencia por los espacios incalculables que prepara la voluntad. La simple imagen de una vida, articulada en el mero proceso de su inmanencia, era realidad inconcebible para el francés de los siglos XVII y XVIII. El hombre no era construible en función del destino que él mismo se trazase. Tales eran los ingentes obstáculos que hizo estallar el nuevo humanismo del pensar romántico, para el cual fue el hombre abismo insondable y a la vez eje del universo. De aquel titanismo romántico hecho problema, de su trágico derrumbe, brotó la auténtica posibilidad de regresar a la fuente remota del novelar de Cervantes. Para Schelling (Philosophie der Kunst, 1803) aún no existían sino dos novelas: el Quijote y Wilhelm Meister, ésta muy inferior a aquélla, dice el gran filósofo. La Europa postromántica, desde Balzac a Pérez Galdós, permitió a esos y a otros escritores geniales enfrentarse con el terrible asunto del poder-no-poder forjarse el hombre el curso de su propio existir. Lo cual, después de todo, no era necesario que aconteciese; el arte de Shakespeare y el de Dante no han tenido continuadores, y sus obras han permanecido como ingentes pirámides que atraen turistas, pero no engendran estilos "piramidales". Cuando se conciba el realizarse de la literatura como una creación desde los senos inmanentes del vivir, y no como evolución, continuidad exterior, o cualquiera otra ingenuidad, será posible dar respuesta digna a estos y otros problemas.

El bueno de Avellaneda (valioso a su modo, según tan sutilmente nos hace ver Gilman) no sólo pretendió rivalizar con 
Cervantes; obró, en realidad, como un jefe de bien atrincheradas mayorías que da un paso al frente para increpar y reducir a buen orden al atrevido Cervantes. Al tal Licenciado, y a la infinita cohorte de sus secuaces, parecía escandaloso que un pobretón alcabalero, manco por más señas, se arrogase la facultad de construir un mundo de gentes según "viene a cuento a cada uno" y "quilatando con su estimación las cosas".

AMÉrico CASTRO

Princeton University 



\section{PREFACIO}

Hay algo paradójico en el lugar que ocupa el Quijote apócrifo en la historia de la literatura española. Los artículos, los libros, las notas a que ha dado lugar son tan numerosos como los de cualquier otro capítulo de esta literatura. Aun sin haber hecho una investigación exhaustiva, he logrado contar, si no leer, unos ciento cuarenta trabajos dedicados a Avellaneda y su obra. La paradoja es ésta: casi ninguno de los críticos, salvo las excepciones nada sorprendentes de Menéndez y Pelayo y Menéndez Pidal $^{2}$, se ha ocupado en lo más mínimo de la novela misma. Lo usual ha sido intentar la identificación del autor, proponer diferentes razones por las que éste pudo o no haber sido tal o cual contemporáneo de Cervantes. Si todos los grandes escritores deben forzosamente tener su "problema literario", Cervantes ha venido a tener el suyo por obra y gracia del Quijote apócrifo.

Yo mismo, antes de preparar el presente libro, publiqué un artículo en que defendía la opinión nada original de que Avellaneda fue un dominico de Aragón. Mi intención por entonces era hacer caso omiso de toda preferencia por un dominico y aragonés determinado, y sacar únicamente conclusiones que el texto mismo pudiera justificar. Si Avellaneda encomiaba a Aragón más que a ninguna otra región de España (colocando allí las principales aventuras de don Quijote) y si en su prosa se encuentran

1 Marcelino Menéndez y Pelayo, Introducción al Quijote apócrifo, Barcelona, 1905.

2 Ramón Menéndez Pidal, Un aspecto en la elaboración del "Quijote", Madrid, 1924. 
indudables aragonesismos, nada más probable que él mismo fuese aragonés. Así también el hecho de que su estilo abunda en referencias a cosas religiosas y eclesiásticas y de que atribuye cuanto hay de bueno a la orden dominicana, me hizo suponer que era dominico. Rehuí lo más que pude los criptogramas y los prejuicios. A eso se reduce mi artículo?.

Pero mi lectura del Quijote apócrifo tuvo resultados de mayor alcance. En cuanto novela, me llamó la atención por ser tan distinto de cualquier otra novela española que yo conozca. Es un libro extraño y, a mi ver, significativamente ajeno al Quijote original, y además no parece tener paralelo en ninguno de los tipos de novela contemporáneos. El falso don Quijote se apropia una armadura que un caballero morisco, don Álvaro Tarfe, le había encomendado, y sale, acompañado de Sancho, con rumbo al torneo de Zaragoza. Esto, naturalmente, coincide con el plan que Cervantes había anunciado al final de la Primera parte y que hubo de cambiar al aparecer la obra de Avellaneda. En el camino a Zaragoza, le ocurren a don Quijote muchas aventuras, algunas de las cuales recuerdan las de Cervantes, aunque en su mayoría son originales. En Ateca, por ejemplo, roban a Rocinante, y en Zaragoza llevan preso al propio don Quijote. En el primer caso le ayuda un amable sacerdote aragonés llamado Mosén Valentín, y en el segundo, don Álvaro y su amigo don Carlos, quienes lo vuelven a encontrar en el torneo; aquí los dos lo presentan a sus amigos como una especie de "gracioso" y logran que vaya a Madrid, donde piensan aumentar su prestigio social explotando su locura. Entre Zaragoza y Madrid, don Quijote y Sancho encuentran a un tercer compañero, Bárbara "la mondonguera", una especie de Celestina cómica, si cabe tal

3 Véase "Alonso Fernández de Avellaneda, a reconsideration and a bibliography”, Hispanic Review, XIV, 1946, págs. 304-321. 
cosa. Se interpolan también dos cuentos más bien siniestros y deprimentes. Por último, cuando sus empresarios, por decirlo así, ya no lo necesitan, don Quijote es encerrado en un manicomio. Este final contrasta asombrosamente con el final de la auténtica Segunda parte. En vez de morir de desengaño ante el derrumbe de su sueño, don Quijote va a dar con sus huesos en una casa de locos.

A diferencia de Menéndez y Pelayo, a mí no me impresionó tanto lo brutal y obsceno de este relato como los cambios que en él sufren el carácter y el papel de don Quijote. ¿Por qué se llama ahora el Caballero Desamorado y no quiere ya a Dulcinea? ¿Por qué las aventuras se desarrollan con tanta frecuencia en las ciudades y no en el escenario pastoril cervantino? ¿Qué psicología literaria se esconde tras los interminables y patológicos monólogos del Caballero? ¿Cómo se explica que casi no haya diálogos en el libro? ¿Para qué la nueva armadura y el tercer compañero? Sobre todo: ¿a qué se debe el desprecio que constantemente muestra Avellaneda por su héroe? ¿Tiene esto alguna relación con su extraño empeño de imitar a un autor por el que, según todas las apariencias, sentía aversión? Mientras pensaba yo sobre estos y otros problemas, tratando de encontrar una respuesta común para todos ellos, empecé a cerciorarme más y más de que los habituales intentos de identificar a Avellaneda no sólo son de muy dudoso éxito, sino también innecesarios e indeseables.

El problema de la paternidad del Quijote apócrifo no es como el de la Celestina. Si el lector de la Celestina no tiene una opinión, razonable por lo menos, acerca del número de sus autores, su juicio crítico perderá en valor. Pero en el caso del Quijote apócrifo hay un solo autor; sería interesante saber quién fue, pero no indispensable. El texto existe como un todo uniforme y como tal se puede leer. ¿Por qué es, además, indeseable averiguar 
la identidad del autor? Es una conclusión - arbitraria quizás y sorprendente si se separa de su contexto - a que llegué al considerar que "puesto que Avellaneda escribía partiendo del punto de vista colectivo, era conveniente que quedara anónimo".

La explicación de esta opinión no es, sin embargo, el único propósito del presente estudio. El Quijote apócrifo, pese a la tradición crítica que ha provocado, es más que una simple paradoja literaria. Si no llega a ser una gran obra de arte, si en muchos sentidos no se puede considerar siquiera como obra de arte, es sin embargo testimonio importante de muchos problemas estéticos e históricos fundamentales. El concepto del barroco no puede ser completo si no se toma en cuenta el tipo especial de barroco que representa el Quijote apócrifo. Esta obra pone en claro también el proceso de imitación literaria en su época, época en que la imitación no era necesariamente una práctica deshonrosa. Señala algunos de los factores que determinaron la decadencia de la novela en el siglo XVII, cuando Cervantes había consumado, monumentalmente, la creación del género. Es ilustración viva de varias de las formas y fuerzas que en aquel tiempo se opusieron a Cervantes. Así, pues, el Quijote apócrifo no es tanto el revés del tapiz cervantino, ni pretende hacernos ver aquello que Cervantes no era, sino que tiene valor en sí mismo. Como trataré de mostrar, la obra representa una concepción ideológica y axiológica nuclear, frente a la cual se podrán colocar, en fecundo contraste, todos los grandes artistas del Siglo de Oro. Así, refleja una especie de coeficiente de normalidad, al que podrían referirse los diferentes estilos aislados y complejos de la época.

El presente estudio es resultado de la revisión completa de una tesis doctoral escrita en la Universidad de Princeton bajo la dirección de Américo Castro. Su crítica y sus consejos han sido decisivos; más aún: lo que me ha servido de inspiración es todo 
su concepto de la ciencia literaria, y a él debe este libro lo que de valioso pueda contener.

Tengo también deuda de gratitud con los profesores Augusto Centeno y Gilbert Chinard, de la misma Universidad, con el primero por haber propuesto, después de leer el original, la revisión de varios pasajes, y con el segundo no sólo por sus valiosas observaciones desde el punto de vista de la literatura francesa, sino también por su ayuda para obtener un subsidio del American Council of Learned Societies, gracias al cual pude terminar la tesis. Por último, quisiera expresar mi agradecimiento a The Ohio State University, en la que trabajo ahora, por haber posibilitado la traducción al español. 

 \\ INTRODUCCIÓN: \\ LA GÉNESIS DE LOS ESTILOS BARROCOS}

Nunca se ha comprendido del todo la íntima relación del barroco con la ideología de la Contrarreforma, particularmente con la de sus representantes ascéticos ${ }^{1}$. La razón aducida en general por los críticos que niegan todo parentesco entre ambas corrientes es el lapso que separa, por ejemplo, el Concilio de Trento del período en que alcanzaron pleno desarrollo el conceptismo y el culteranismo ${ }^{2}$. Hay, sin embargo, otra razón posible para negar el parentesco, y es el hecho de que al barroco, a diferencia del romanticismo, se le ha desvinculado de sus corolarios ideológicos o filosóficos. El barroco -término usado primero para la historia de las artes plásticas - se ha concebido con demasiada frecuencia como una mera crisis de la forma, como una complicación de los estilos, como cristalización de las técnicas de expresión renacentistas y simple etapa en el cambio hacia el "rococó". Se podrá objetar que los mismos estilos barrocos, con su difícil autonomía, no pretenden comunicar ideas o visiones fundamentales de la vida. La respuesta a esto es, como veremos, que no sólo es esta objeción más apa-

1 Este problema, asunto de la presente introducción, se estudia con alguna mayor amplitud en mi artículo "An introduction to the ideology of the Baroque", Symposium, I, 1946.

2 Se podría mencionar a Dámaso Alonso y a Aubrey F.G. Bell como los más sobresalientes entre los críticos que niegan la relación. 
rente que real (y Calderón nos servirá de ejemplo), sino que todo estilo que logra una amplia aceptación, como el barroco, es valoración de la vida y como tal se le ha de considerar. La tendencia a definir el barroco como una especie de "ismo" literario (marinismo, gongorismo, conceptismo) que se propaga a través de las fronteras nacionales a modo de epidemia, consecuencia inevitable de las estancadas formas renacentistas, sólo sirve para separar el estilo de su significación humana, de las profundas raíces que tiene en las ideas y valores del hombre.

Si hemos de usar el término "barroco" en forma crítica, de la misma manera que pueden usarse los de romanticismo y neoclasicismo (por más pasados de moda que estén), si hemos de hallar en él una clave que nos indique lo que Avellaneda era y Cervantes no era, entonces será necesario que revisemos aquellas definiciones. Debemos poner a un lado los aspectos internacionales y técnicos del barroco y volver a sus aspectos ideológicos y nacionales. Sólo así podremos conocer el barroco en cuanto fuerza armónica que moldea la expresión en el Siglo de Oro, fuerza que da lugar a estilos al parecer distintos pero, no obstante, profundamente relacionados. Sólo de este modo podemos evitar que el barroco se desintegre en escuelas y generaciones inconexas y percibir su esencia en la "extraliteraria” y prosaica prosa de la imitación de Avellaneda.

Entre los diferentes tipos de expresión escrita de la Contrarreforma, el ascetismo fue el único que reveló plenamente aquel conflicto ideológico ${ }^{3}$. Los neoescolásticos volvieron a

3 Usamos aquí el término ascetismo en un sentido no técnico sino general, aplicándolo a aquellos escritos en lengua vulgar cuya intención era explicar y enseñar la manera católica de vivir: literatura hecha especialmente para los miembros laicos de la Iglesia. Así, por ejemplo, consideraríamos autor ascético a San Ignacio. 
definir desde fuera las bases dogmáticas del impulso vertical de unión con Dios y los místicos exploraron desde dentro los medios emocionales de ese impulso, pero ni los unos ni los otros afrontaron el problema de la nueva relación - resultado forzoso de la unión con Dios - entre el hombre y el mundo que lo rodea. Uno hablaba de la humanidad, el otro de sí mismo, pero nadie se ocupó en hablar al hombre, es decir, al lector. Esta tarea quedó para los escritores ascéticos. A éstos y a los instrumentos más conocidos del Índice y de la Inquisición quedó encomendado el trabajo de comunicar a los creyentes y cuasicreyentes la nueva afirmación de la fe católica. Fueron defensores, polemistas, propagandistas. Es, por supuesto, imposible separar rigurosamente las tres maneras de escribir. No se trata aquí de señalar diferencias evidentes entre escuelas literarias, sino de reconocer los distintos tipos de intención implicados en el pensamiento contrarreformista. Un mismo autor o una misma obra, claro está, pueden revelar una mezcla de intención mística con intención neoescolástica o ascética; sin embargo, es posible establecer esa división, aunque sólo fuera porque se desprende de las necesidades internas del impulso contrarreformista en su integridad. San Juan de la Cruz, Francisco Suárez y Hernando de Zárate son quizás los más típicos representantes de los tres tipos de intención.

¿Cuáles eran las fuerzas ideológicas y los valores humanos contra los cuales lucharon los escritores ascéticos, y qué nuevos valores y fuerzas procuraron imponer en su lugar a los lectores? Antes de intentar la respuesta, reproduzcamos un pasaje de Zárate, valioso para comprender la actitud que ante la vida tenían no sólo Avellaneda sino también la mayoría de los grandes escritores del Siglo de Oro: 
Para averiguar pues cuán corta es nuestra vida y cuán sin pensar se pasa, ni son menester libros ni mirar lo que los autores dellos desto sintieron, ni preguntar en qué pararon los príncipes y reyes que más larga se la prometían y procuraban, ni qué se hicieron los filósofos, los sabios, los poetas famosos... ni qué se hicieron las armas, municiones y letras, ninguna cosa es necesaria; sino después de haber considerado sola la mudanza que nuestra propia muerte ha hecho en tan breve tiempo en nuestras mesmas personas, las cuales va desde el principio comiendo y acabando, remitiendo la virtud y aflojando las fuerzas, señalando el rostro con canas y rugas y falta de dientes y de vista... de manera que cuando ya viene [la muerte] por nosotros, apenas halla qué llevar, sino la triste vida... Cada uno cuente en su pensamiento y memoria los que le tocan y los que ha conocido, y dirá: ¿Qué se hizo mi padre, mi madre, mis hermanos, mis vecinos, Fulano y Fulano que yo conocí, Fulano que gobernaba, etc.? ...dice Job, que el hombre nacido de mujer vive poco tiempo y ése lleno de miserias, y que huye ligero como una sombra, y nunca, mientras vive, permanece en un mesmo ser... Ciertamente el hombre que vive es un montón de toda vanidad, y todo se pasa en farsa o figura; y así, sin propósito se turba... Otros dicen que nuestra vida es humo, otros sombra. Los malos, que suelen reírse desta sentencia por parecerles que tienen experiencia de lo contrario, la vienen a confesar en el infierno; allí la comparan a sombra, que en un instante nace y en otro muere; y su vida y ser es no ser; compáranla los mesmos a correo, que pasa con gran priesa, y aun a decir las nuevas no quiere parar... Pues la divina Escritura nos pinta como justadores con la muerte con gran velocidad; porque de nosotros dice que partimos para ella como un arroyo de agua o río, el cual vemos que corre con tanta velocidad, que apenas se conoce en la tierra otra mayor; porque aunque un río vaya manso al parecer (en que también es semejante a nuestra vida, porque acaece estarle mirando y asomar por la parte alta del río un corcho sobre el agua, y caminar al parecer tan despacio, que no llega a nosotros en media 
hora, ni se desaparece en otra media), pero el agua sin duda va con gran velocidad; lo cual se verifica en una rueda de molino que ella mueve, la cual se pierde casi de vista de pura ligereza; y del otro de grandes fuerzas se dice que las probó en quererla detener, y le reventó la sangre por los oídos. Y esta velocidad es claro que le viene del agua... que parece venir mansa, pues de donde se continúa el agua se continúa la fuerza, con la cual suele un río llevarse los árboles y los peñascos que delante se le ponen, y arruinar casas y barrios enteros de las ciudades y las presas o pesqueras de las aceñas, dejando espantados a los que miran desde las riberas; así es la vida del hombre, que mirada a lo que parece va de espacio; de manera que se pasan diez, veinte, cuarenta años sin que en la vida de un mancebo se eche de ver la mudanza; pero en realidad de verdad va corriendo velocísima como el río... Pues si comparamos la mesma vida con la eternidad no queda comparación... Bien se entiende la causa por que el hombre, aun puesto a considerar esta verdad, no la entiende o no le mueve, porque el demonio, como gran pintor, pinta las cosas que están cerca que parezcan lejos; y así, pinta lejos la muerte y la otra vida, aunque realmente están muy cerca ${ }^{4}$.

Salta a la vista la semejanza que hay entre este pasaje y gran parte de la obra de Mateo Alemán, Calderón y otros, pero su importancia no depende tanto de los reflejos posteriores que recordaban su tono moralizador, como del efecto decisivo que tuvo el conflicto de ideas y valores reflejado en él. Este conflicto se explica por el hecho de que Zárate estaba más que nada interesado en persuadir al lector de la necesidad de abandonar un sistema de valores e ideas para adoptar otro. Por lo tanto, era menester presentar en sus escritos los dos sistemas y mostrar

4 Fray Hernando de Zárate, Discursos de la paciencia cristiana, Biblioteca de Autores Españoles, XXVII, Madrid, 1853, págs. 517-519. (Salvo indicación en contrario, las cursivas serán siempre mías.) 
con su estilo la lucha que entre ambos debía efectuarse en el alma de cada hombre. De este modo, Zárate y los demás pensadores ascéticos, a diferencia de los neoplatónicos, neoescolásticos y místicos, no presentaban la vida como un movimiento único, sino como un dualismo.

El carácter del dualismo en Zárate nos lo revela la insistente repetición de la palabra "parecer", repetición que no sólo pone de relieve su idea de la falacia de la percepción humana, sino que también descubre el temor a la seducción de que esta falacia es capaz. Zárate sabía que la confianza que el individuo pone en las cosas que puede ver, tocar, oler y oír puede acarrear una desconfianza de las cosas no directamente comprobables. La consecuencia fatal será, pues, la confianza, hedonista o científica, en el hombre y la no sujeción al orden divino. Los autores ascéticos tenían una frase especial para designar a aquellos que, engañados por la apariencia de las cosas, habían llegado a esa seguridad; les llamaban "los confiados en sí mismos". Que Zárate identificaba este peligro con ciertos rasgos del Renacimiento se ve en su metáfora del río "manso al parecer", reminiscencia indirecta de las suaves corrientes de Garcilaso. El mundo de la percepción, del río tranquilo tendido en perspectiva horizontal ante los ojos del hombre, había logrado por primera vez importancia artística vital durante el Renacimiento. El hombre comenzaba a confiar en su capacidad de enfrentarse a los problemas de su vida en sus propios términos. A este engaño del "parecer", los escritores ascéticos opusieron la verdad del "ser", verdad no percibida sino concebida.

El dualismo de Zárate es, pues, algo más que el dualismo medieval de cielo y tierra, aunque estos dos planos constituyan su base. No es tampoco un dualismo de lo católico contra lo protestante, aunque la separación que los protestantes estable- 
cían entre el hombre y Dios, entre razón y fe, debió parecer a los pensadores ascéticos consecuencia de la confianza en las apariencias del mundo. De un modo esencial, el dualismo de Zárate oponía la autónoma necesidad humana de un mundo basado en Dios y centrado en el hombre, a la experiencia viva que el hombre tiene de un mundo que no satisface ninguno de esos requisitos. La verdad concebida lógicamente se opone a la verdad percibida vitalmente.

El hecho de que la actitud renacentista ante la vida fuese blanco de la polémica ascética nos lleva a suponer que había en esta actitud cierta debilidad que dio fuerza a la reacción. Durante la Edad Media, el hombre se había acostumbrado a la reconfortante creencia de que el universo se había creado sólo en provecho suyo, que su especie era dueña y señora de la mansión terrestre. El Renacimiento continuó creyendo lo mismo, pero en lugar de decir "especie" dijo "individuo". Por desgracia, sólo era posible confiar en el contacto directo entre el individuo y su mundo inmanente dentro del ambiente suave, verde, concéntrico, intemporal de la ficción pastoril. Tan pronto como los sentidos trataban de captar los accidentados paisajes reales, éstos parecían extraños, fríos y como divorciados del hombre y de sus intereses. La tristeza que provocó en don Quijote el aspecto del mar desde la playa de Barcelona es un magnífico ejemplo. Aubrey F.G. Bell, para ilustrar su tesis de que la nueva percepción horizontal había destruido las raíces del mundo interior, cita una serie de pasajes del Siglo de Oro en los que se hace manifiesta la aversión del paisaje de mar o de montaña ${ }^{5}$. Pero fue Fray Luis de Granada quien formuló la principal objeción al énfasis que el Renacimiento ponía en el conocimiento directo de la naturaleza:

5 Véase “The Renaissance in Spain”, RHi, LXXX, 1930. 
...No hace al hombre bienaventurado la posesión de los bienes, sino el cumplimiento de sus deseos ${ }^{6}$.

Este cumplimiento cabal sólo podía lograrse a través de Dios, y para lograrlo había que reconstruir el impulso vertical de unión del hombre con Él, sustituir el espacio y el tiempo percibidos, el "parecer", por la concepción del infinito, de la eternidad. Esto podía alcanzarse por medio de la fuga, del desdén o del combate; en general, la literatura postridentina refleja alguna de estas actitudes pesimistas. Los autores ascéticos, como vimos en la cita de Zárate, escogieron la tercera, y, como veremos más adelante, una de las consecuencias de esta épica ansia de combate fue la aparición del barroco.

Por supuesto, los medios filosóficos de la lucha ascética no eran los del neoplatonismo pastoril del Renacimiento. El título mismo de la obra de Zárate, Discursos de la paciencia cristiana, y su oposición al elemento sensorial del dualismo revelan claramente que su filosofía no era de unión, sino de resistencia. Fue una variante del estoicismo. La posición intelectual y apartadiza ante la realidad, el alejamiento del mundo que el escritor se imponía a sí mismo son uno de los rasgos más característicos del ascetismo. Los autores ascéticos rechazaron el neoplatonismo, disciplina de la voluntad de amar no sólo a Dios sino también la belleza del mundo, y hallaron en el estoicismo una disciplina intelectual de resistencia y de odio que podía servir de arma contra el mundo de las apariencias. Sin embargo, tuvieron cuidado en rechazar aquellos principios del estoicismo que pudieran llevar a la "confianza en sí mismo". Hallaron en Job y en San Mauricio la justa combinación de

6 Fray Luis de Granada, Guía de pecadores, Biblioteca de Autores Españoles, VI, Madrid, 1856, pág. 117. 
resistencia a lo mundano y subordinación a lo divino; fueron ambos los héroes ejemplares de los ascetas, la flor de la caballería del estoicismo cristiano.

Si la intención de los escritores ascéticos fue polémica, si su enemigo fue la autoseguridad renacentista y su pasión el odio, la técnica a que apelaron se basaba en el intelecto. Fue una técnica de contrastes lógicos; Zárate nos da una muestra clara en el pasaje citado: "Pues si comparamos la misma vida con la eternidad, no queda comparación". No se menciona lo absoluto porque sea perfecto, sino a fin de oponerlo a lo relativo; lo infinito se aplica continuamente a lo finito y lo eterno a lo temporal para que en el contraste resalte más la bajeza de lo temporal y finito. Pero este proceso no destruye, sólo desfigura. Los conceptos lógicos de infinito y eternidad se convierten en instrumentos del desengaño al negar la validez de las sensaciones. La percepción de los sentidos se desfigura dentro del mundo, en la relatividad de su tiempo y de su espacio. Contrastado con lo absoluto, el tiempo acelera su ritmo y el espacio se acorta y se hace confuso e ilusorio. Los objetos conservan sus formas pero pierden la significativa materialidad de su existencia, y cualquier sensación por ellos provocada se vuelve en seguida sospechosa. Puesto frente al portento de la verdad absoluta, el lector tiene que darse cuenta de lo inseguras que son las revelaciones de los sentidos. Los martillazos del infinito reducen a aparición la apariencia.

Buscando más ejemplos en Zárate, notamos la insistencia con que vuelve sobre palabras como "humo", "sombra", "farsa" y "figura", metáforas todas que acentúan el carácter insustancial de la existencia humana. La experiencia, que es el gran tema cervantino rechazado por Avellaneda, sólo tiene importancia para "los malos", quienes después han de atacarla desde 
el punto de vista absoluto encarnado en la eternidad del infierno. En cuanto al tiempo, su dinámica aceleración más allá de los límites del curso natural de la vida convierte el "manso río" en torrente impetuoso que arrastra cuanto encuentra. Vemos, por último, que es el demonio quien ha inventado el engaño de la perspectiva, y con ello todo el mundo visual inmanente a cada hombre, mundo que, como lo muestran las ilustraciones medievales, no se había descubierto antes del Renacimiento.

Sería bueno volver a insistir aquí en el hecho de que la apariencia - la realidad empírica - continuase existiendo para los autores ascéticos. No se pasa por alto lo que se odia; como en el caso del odio de Avellaneda por Cervantes, se concentra uno en lo odiado para zaherirlo, o para destruirlo. Presencia, forma, color, tacto, sonido y olor permanecen como elementos básicos del estilo de estos escritores (contrastando con los místicos y con los neoescolásticos, que se refugiaron los unos en la oscuridad del alma y los otros en la claridad del intelecto). La presencia del "parecer" en este estilo es, como se ha dicho, la base de su dualismo; es esencial en el método de doble plano, en el continuo contrapunto lógico entre el aquí y el allá que resulta de la zanja abierta entre la percepción de la realidad y su interpretación. En consecuencia, aunque se transformó el virus de lo inmanente anulándolo con la medicina del infinito y de la muerte, no se le mató. Estos médicos del alma, como conocían muy bien las fuerzas y debilidades de su adversario, sabían que no habían de matarlo, y sólo intentaron restarle importancia, hacerlo inofensivo. No pudieron darse cuenta, sin embargo, de que su tratamiento podía conducir, en el organismo espiritual, a complicaciones más sutiles y duraderas que la curación que ellos proponían.

Aunque los escritores ascéticos lograron un éxito sorpren- 
dente al eliminar las justificaciones peligrosas del pecado, o sea aquellos elementos de la visión renacentista del mundo que permitían al individuo pasar por alto lo inmediato de su relación con Dios y crear fórmulas personales sobre el bien y el mal, no pudieron sin embargo desterrar el pecado en sí: el carácter mismo del arma que utilizaban, del dualismo, lo impedía. La vida de los sentidos continuó y aun aumentó, pero más como "frenesí deleitable" (esta frase no es de Calderón ni de Tirso, sino de Fray Luis de Granada) que como un fin o valor en sí mismo. Se trataba de "desengañar" al lector más que de reformarlo. El hombre ideal de esa época no era tanto el "honnête homme" moderado y virtuoso, como el desilusionado, el hombre a quien Malón de Chaide llamaba el "caído en la cuenta". Para semejante hombre las sensaciones aumentan quizás en violencia, en color, placer y sensualidad; esta tendencia la podemos observar en el estilo de escritores ascéticos como Malón de Chaide, pero el "caído en la cuenta" nunca debe tratar de encontrar en estas sensaciones ninguna significación definitiva. De hecho se deseaba este incremento de vigor sensual para que quedara patente su falacia. Así se explica el paso de la novela pastoril a la tardía novela picaresca. Se prefería ahora la lujuria al amor idealizado: era menos probable que el hombre entregara su alma a aquélla. También vinieron a menos otros valores, ideas y características tradicionales, según veremos continuamente en el Quijote de Avellaneda. Las cualidades renacentistas de "desenvoltura" y honor, las ideas de fortuna y naturaleza, el sueño característico de la perfección humana pasada y futura, la importancia misma que el Renacimiento daba a los sueños del hombre, todas estas cosas fueron tratadas despectivamente o desnudadas de su valor por los escritores ascéticos. Se las hacía aparecer como males o se 
las reducía a formas hueras, a simples cáscaras de creencia y conducta.

En cuanto al individuo, el irresoluble dualismo creado por los pensadores ascéticos para desengañarlo alteró su interpretación estética y metafísica de la vida. El choque de lo eterno con lo temporal aceleró su sentido del tiempo e hizo que viviera constantemente a la sombra de la muerte. El choque de lo infinito contra lo finito exageró y confundió las perspectivas que irradiaban del hombre, y convirtió la corriente interior de percepciones en una fantasmagoría de ficciones muertas, inconexas e inconstantes. El marco lógico de la jerarquía eclesiástica, política y social no se alteró y siguió sostenido el cuadro desde fuera. Pero por dentro, la creación se rindió a la decoración, la estructura orgánica a la autonomía de las partes, la vida a la ilusión, la dignidad rectilínea a la tensión de la curva. Esta combinación de jerarquía formal y derrumbe interior tenía su paralelo en la alternancia de rigidez y frenesí característica de la vida española de principios del siglo XVII. El deseo de España de poseer un Dios inmediato - y en esto los autores ascéticos expresaban la voluntad épica de la nación - trajo como corolario inevitable el descubrimiento de que la vida era teatro, de que era un espectáculo en el cual se podía participar pero no hallar la verdad. No era posible unir, como en la Edad Media, la inmanencia a la trascendencia; de ahí la nostalgia de Quevedo por aquellos tiempos en que no había más prosa que "Santiago, muchas veces repetido". A medida que la vida se iba concibiendo más y más como representación teatral, iban aumentando los efectos escénicos. Lo llamativo, lo inútil, lo superficial, el adorno, la decoración, es decir, todas esas cosas sensibles que los pensadores ascéticos nunca trataron de eliminar, crecieron en importancia y dejaron las interpretaciones 
individuales de la vida aun más indefensas, más a la merced de los martillazos de lo absoluto.

Así, cuando el artista llegó a expresar su nuevo ser ya disciplinado por la enseñanza de la Contrarreforma, cuando reveló en su estilo y en sus temas el peso de este mundo nuevo, cuando convirtió la polémica ascética en materia estética, creó el barroco ${ }^{7}$.

Los escritores ascéticos y otros defensores de la Contrarreforma no eran en sí mismos barrocos. Por más que hayan contribuido a las ideas y los valores barrocos, a la actitud humana reflejada en el estilo, fueron polemistas más que artistas y, a pesar del dualismo, su propio estilo estaba destinado en su mayor parte a convencer al lector. Eficacia y claridad eran aquí los recursos literarios más útiles. Toda otra consideración fue subordinada al propósito de la Contrarreforma, a la restauración de la validez universal del dogma por medio de la desvaloración de la verdad personal. Pero el campo de batalla estaba dentro de la mente de los hombres y los objetivos eran valores, creencias, ideas. La lucha pretendía dar nueva forma a los factores que determinan la interpretación de las sensacio-

7 Aubrey F.G. Bell, de acuerdo, en lo fundamental, con Croce y Dámaso Alonso, habla de este cambio en la expresión artística como de una cristalización inherente a la forma renacentista, de una nueva "superficie sin alma”. Pero simplifica demasiado; si la exteriorización del arte y de la vida necesariamente alteró los esquemas anteriores, el significado esencial de la exteriorización, el poder espiritual albergado tras él puede explicarse por la Contrarreforma; no por una Contrarreforma limitada por las fechas del Concilio de Trento, sino por la que siguió después propagando sus principios durante años y décadas. Para Bell y otros el barroco es un Renacimiento decadente; para nosotros, es un Renacimiento transformado por la presión de la voluntad y de la conciencia humanas en una sustancia de valor nuevo. Se trata aquí de una geología de la metamorfosis, no de una sedimentación. 
nes producidas por la realidad y las acciones sobre ellas planeadas; pasada la lucha, la enseñanza se había hecho condición esencial, se habían inventado nuevos estilos que debían reflejar el nuevo ser del hombre. Había nacido el barroco.

Para comprender la posición de Avellaneda, importa observar que esta reexpresión artística podía efectuarse en dos direcciones, según la persona de quien partiera. El artista podía representar sus propios intentos frustrados, en cuanto individuo, de crear obras con sentido dentro de un mundo sin sentido, o bien podía aceptar por entero el antídoto formal religioso-social elaborado por la Contrarreforma. El abismo entre el individuo, en cuanto individuo, y el mundo no podía cerrarse, pero sí era posible reflejarlo artísticamente partiendo de uno de los dos términos del dualismo. Se podía ser artista, para sí mismo y para un grupo selecto de hombres, o bien expresar los valores y creencias de la multitud para la multitud. La técnica de doble filo que usaban los escritores ascéticos dio por resultado dos direcciones artísticas barrocas.

Entre los que escogieron la primera de estas direcciones estaban los conceptistas y los culteranos ${ }^{8}$. El conceptismo, a pesar de haberse manifestado ya de cierto modo en muchas obras de la prosa española anterior, halló su primera expresión significativa cuando Mateo Alemán, al intentar escribir una novela ascética más que un tratado ascético, hizo pasar lo novelesco por la malla de sus doctrinas. En la parte narrativa del Guzmán de Alfarache,

8 Los culteranos, en vez de forjar un estilo a base del dualismo predominante, buscaron un escape individual de ese dualismo, refugiándose en aquellos elementos exteriores de la realidad que no habían sido nunca destruidos por la polémica contrarreformista. En vez de repetir estilísticamente el proceso de su propio desengaño, como lo habían hecho los conceptistas, buscaron refugio en uno de los términos del dualismo, en un universo de teatralidad pura aunque erudita, sorprendente, a menudo, por su encanto. 
en los pasajes que reflejan el ascetismo en términos no ascéticos, es donde por vez primera el imposible dualismo de la Contrarreforma se resuelve en un estilo, en "conceptos" que anuncian a Quevedo y a Gracián. El “concepto” es esencialmente una repetición estilística de la técnica de destrucción del mundo que inventaron los autores ascéticos. Es notable cuántos conceptos aparecen, en Quevedo particularmente, cuando se transforman repentinamente las condiciones mundanas por imponerse lo absoluto. El Infierno o la Diosa de la Fortuna reemplazan al infinito y a la eternidad de los autores ascéticos. Otras veces se invierte el proceso y se hace uso de una categoría verbal de poca extensión, de la boca por ejemplo, esto es, de la boca como concepto absoluto, exclusivamente como receptáculo del alimento, para destruir la unidad orgánica de esa categoría más amplia que es el rostro. De este modo Quevedo puede decir de una barba que está "descolorida de miedo de la boca vecina". El conceptismo es esencialmente negación de la categoría en términos de la categoría, y el conceptista afirmaba su "soledad", su apartamiento del mundo aceptado, trastornando audazmente el estereotipado marco contrarreformista de la lógica universal. Se jugaba con la división en jerarquías y categorías externas al hombre, que habían venido a suplantar la organización interior y poética. El conceptista negaba el rostro, el hombre, la sociedad y hasta el universo afrontándolos con su aislamiento categórico y sirviéndose de la anormalidad de este aislamiento para presentarlos como monstruosidades. El artista desesperado prolongaba el ataque a ese mundo que se había desprendido de él para deshacerse de su angustia personal por medio del expresionismo y de la negación humorística. El filo mismo de las armas ascéticas que había heredado impedía que se pudiera cerrar la brecha.

Hagamos una breve recapitulación con objeto de poder 
comprender mejor la segunda dirección barroca, la dirección que siguieron los que aceptaron la ortodoxia, los no asqueados por el antídoto de la Contrarreforma. Los escritores ascéticos no desmembraron el mundo inmanente por perversidad o porque gozasen al contemplar la destrucción de lo finito por lo infinito; en ese caso ellos mismos habrían sido barrocos. Pero no, ellos tenían una intención; sabían que sólo un mundo desmembrado podía reconstruirse de acuerdo con los planes de la Contrarreforma. Sólo de este modo podía imponerse el esquema ontológico, la totalidad de las categorías ascendentes esbozadas por los teóricos neoescolásticos. Si los conceptistas continuaron con la técnica de destrucción mucho después de haber sido ésta abandonada oficialmente, hubo otros que aceptaban el nuevo orden sin reparo y que vivían de acuerdo con él ${ }^{9}$. Estos otros incluían la gran masa del pueblo, la masa de la que culteranos y conceptistas ansiaban distinguirse, en otras palabras, el "vulgo".

Ahora bien, los escritores que creaban para el vulgo tenían un gran recurso artístico: la reafirmación de los valores comunes por medio de la dramatización. El resultado fue la comedia, caracterizada por estar dirigida directamente a las masas y por ser glorificación de cuanto las masas creían verdadero. La ortodoxia halló nueva expresión y valor artístico en términos de acción humana ejemplar y dramática. Pero el dramaturgo necesitaba separarse del punto de vista de la masa, colocarse en un plano superior recreando individualmente los valores aceptados: necesitaba medir con el arte la distancia entre él y su

9 La gran época del "ascetismo" se puede colocar aproximadamente en la segunda mitad del siglo XVI. Abundan las afirmaciones de carácter "ascético" en el siglo XVII, pero no tienen gran significación dentro de los "tratados" originales. 
público. Aun en la comedia seguía habiendo cierta perspectiva desde fuera, aquello que Augusto Centeno llamaría, en su ensayo The intent of the artist, "apartamiento creador"10.

La historia de la literatura nos ha conservado gran número de comedias, buenas y malas, y muchas novelas que son como comedias, pero de ninguna se nos ha dicho que careciese por completo de este apartamiento básico. Es posible, sin embargo, invertir los términos de este análisis e imaginar un autor que no trate los valores admitidos como un tema dramatizable por el ingenio poético, sino que los considere condición indispensable, estado de cosas, perfectamente aceptado, tan aceptado y natural que casi no se tenga conciencia de él. Por lo tanto estos valores no necesitan especial reafirmación. El posible heredero de los ascetas no apoyaría ni atacaría la concepción ortodoxa de la vida, sino que de ella partiría su creación y él mismo estaría necesariamente en la posición de Adán. La creación sería a la vez sincera e imitadora, puesto que tal creador carecería de categorías artísticas propias que le permitiesen una perspectiva original del asunto. Sería parte integrante de su ambiente ideológico y axiológico sin ser capaz de enriquecerlo o modificarlo por medio de una creación personal. Una obra así podría ser tan absolutamente característica y tan poco excepcional que no se fijaran en ella las generaciones posteriores, pues éstas no hallarían en su ingenuidad estética, en su peculiar "nonatez", el síntoma de una especie interesante y rara (rara precisamente por no ser excepcional) del barroco.

No es necesario ni posible completar aquí esta reconstrucción imaginaria; sin ejemplos carece de valor. Sólo he querido bosquejar una introducción a los temas que se van a tratar en

10 Véase este estudio fundamental de Augusto CenTeno sobre la estética como problema vivo: The intent of the artist, Princeton, 1941. 
el presente trabajo. Porque precisamente creo que el Quijote apócrifo llena muchos de los requisitos citados. En un ensayo anterior, ya mencionado en el prefacio, afirmaba yo que Avellaneda muy probablemente había sido un dominico aragonés, es decir, un hombre del que se esperaría que aceptara la ortodoxia y estuviera condicionado por ella. Me propongo ahora demostrar que la obra de Avellaneda es barroca, en cuanto representa esa posibilidad del barroco a que me he referido, posibilidad opuesta a las de un Quevedo o un Góngora, pero tan barroca en esencia y tan alejada como ellos del Quijote de Cervantes. 


\section{CERVANTES Y AVELLANEDA}

\section{El Destierro DE LOS Libros DE CABALLERÍAS}

La única semejanza que Avellaneda, según él, tiene con Cervantes es la actitud ante los libros de caballerías:

...tenemos ambos un fin, que es desterrar la perniciosa lición de los vanos libros de caballerías, tan ordinaria en gente rústica y ociosa... ${ }^{1}$

Es posible que esta supuesta semejanza pueda aclararnos el odio de Avellaneda por Cervantes mejor que los tan discutidos insultos en el prólogo del Quijote apócrifo. El llamar a Cervantes "viejo", "mal contentadizo" y decir que la Primera parte del Quijote es "...quexosa, murmuradora, impaciente, y colérica, cual lo están los encarcelados", más que descubrir las razones que impulsaron a Avellaneda al odio, revela las consecuencias de esta pasión. Debe haber algún hondo desacuerdo personal que explique no sólo los citados comentarios de Avellaneda, sino también el contraste entre los dos Quijotes².

1 El Quijote apócrifo, Barcelona (Librería Científico-Literaria), 1905.

2 Como no conocemos realmente a Avellaneda en cuanto personaje histórico, todas las explicaciones positivistas de la enemistad son inseguras y por lo común se han basado en una identificación determinada. Poco importa que, por ejemplo, el nombre de "Sancho Panza" haya sido un apodo popular de Fr. Luis de Aliaga y que Cervantes lo haya usado ma- 
La posibilidad de que Avellaneda fuese dominico o por lo menos eclesiástico parece ser confirmada por los términos que usa para condenar los libros de caballerías. Las expresiones "perniciosa lición" y "vanos libros" implican una actitud moral, muestran que a Avellaneda le preocupaba más el posible efecto pernicioso sobre el público que el hacer una crítica del valor artístico del género. Juzga de acuerdo con las enseñanzas religiosas y el provecho social y no con criterio literario. El agustino Malón de Chaide, que pone las novelas caballerescas al lado de las pastoriles, ilustra aun más esta reacción típica de la Contrarreforma:

...libros lascivos y profanos, a donde y en cuyas rocas se rompen los frágiles navíos de los mal avisados mozos, y las buenas costumbres... Porque ¿qué otra cosa son los libros de amores y las Dianas y Boscanes y Garcilasos y los monstruosos libros y silvas de fabulosos cuentos y mentiras de los Amadises, Floriseles, y Don Belianis... puestos en manos de pocos años, sino cuchillo en poder del hombre furioso?... Y ¿qué efecto ha de hacer en un mediano entendimiento un disparate, compuesto a la chimenea en invierno, por el juicio del otro que lo soñó? Pues para reparo de los muchos daños que de estos libros nacen, muchos celosos de la honra de Dios y amigos del bien y medra de los fieles, han tomado la pluma y han escrito libros llenos de santa doctrina... ${ }^{3}$

Los polemistas de la Contrarreforma identifican, pues, los

liciosamente, o que haya o no un ataque oculto a Avellaneda en los versos burlescos que preceden a la Primera parte; lo que interesa es comprender la separación vital entre los dos autores tal como se expresa en sus divergentes tratamientos de un mismo tema.

3 Diego Malón de Chaide, La conversión de la Magdalena, Clásicos Castellanos, Madrid, 1930, vol. I, págs. 58-63. 
libros de caballerías con todos los peligros del sueño mundano, a pesar de que los consideran, a diferencia de las novelas pastoriles, más peligrosos para el "entendimiento" que para la "voluntad" . Además de rivalizar con la literatura devota, representaban toda la odiada autoconfianza del Renacimiento. Fue el mismo Malón de Chaide quien consideró "las quimeras que soñastes", es decir, el solo acto de soñar la felicidad terrestre, como pecado mortal.

Este tema se repite constantemente a lo largo del Quijote apócrifo. La curación que se recomienda a don Quijote consiste no sólo en eliminar los "vanos y perniciosos" libros de caballerías, sino además en hacerle leer, en sustitución, la Guía de pecadores de Fray Luis de Granada y las vidas de santos, y rezar frecuentemente el rosario. Y cuando don Quijote, a pesar de este tratamiento ascético, vuelve a su locura, se nos hace ver que es porque sucumbe a la tentación; Sancho aparece aquí como tentador. La larga advertencia del cura modelo, Mosén Valentín, podrá servirnos, como tantos otros pasajes, para mostrar la insistencia con que se ataca el género caballeresco en la obra de Avellaneda:

- Vuesa merced, señor Quijada, se podrá ir cuando fuere servido; pero advierta que yo no soy Lirgando, ese mentiroso sabio que dize, sino un sacerdote honrado que, movido de compasión de ver la locura en que vuesa merced anda con sus quimeras y caballerías, le he recibido con fin de dezirle... cómo anda en pecado mortal... dando nota de su persona, y haziendo tantos

4 Castro ha reunido en el Pensamiento de Cervantes una lista de críticas de los libros de caballerías, hechas en el siglo xvi, en la cual se ve que cerca de la mitad de los críticos parecen asumir esta particular actitud. No creo que se haya mencionado hasta ahora la condenación moral, muy semejante, de Mateo Alemán. 
desatinos... Le cogerá tal vez la Hermandad, que no consiente burlas, y le ahorcará, perdiendo la vida del cuerpo, y lo que peor es, la del alma; tras que anda escandalizando, no solamente a los de su lugar, sino a todos los que le ven ir desa suerte armado por los caminos... Pues me dize Sancho que vuesa merced tiene razonablemente hacienda, gástela en servicio de Dios y en hazer bien a los pobres, confesando y comulgando a menudo, oyendo cada día su misa, visitando enfermos, leyendo libros devotos y conversando con gente honrada, y sobre todo con los clérigos de su lugar... porque vea vuesa merced cómo deseo yo más su alma y el bien de su alma, que vuesa merced proprio. Y deje esas vanidades de aventuras, o por mejor decir, desventuras ${ }^{5}$.

El don Quijote de Avellaneda se nos muestra aquí como aquel hombre de "mediano entendimiento" de que hablaba Malón de Chaide, y el Quijote apócrifo como el retrato del "efeto" que sobre él hicieron los libros de caballerías. Así pues, la crítica que Avellaneda hace de este tipo de literatura es la crítica contrarreformista; refleja la censura oficial de todos los libros, por castos que fuesen, que tendían a separar lo humano de lo divino y establecer un plano humano autónomo. El estilo y el énfasis de esta advertencia recuerdan los tratados ascéticos tan a menudo recomendados en el Quijote apócrifo. No pretendemos decir que Avellaneda fue, a su vez, un autor ascético (como veremos, no lo fue), pero hay que recordar que, puesto que era clérigo, el ascetismo constituía un aspecto importante de su formación literaria y filosófica; siempre que el desarrollo de la obra da lugar a una guerra abierta contra el pecado o el error, cae naturalmente en el estilo ascético.

Si los juicios de Avellaneda contra los libros de caballerías no dejan lugar a dudas, todavía no se ha determinado cuál era

5 Quijote apócrifo, págs. 57-59. 
la posición de Cervantes a este respecto. La intención que tuvo Cervantes al escribir su libro es, naturalmente, más profunda de lo que se pudiera pensar por la circunspecta frase del primer prólogo: “...derribar la máquina mal fundada destos caballerescos libros..."; sin embargo, no deja de haber en el Quijote una crítica literaria de las novelas de caballerías, y si se la contrasta con la de Avellaneda, se nota claramente el fundamental antagonismo ideológico que existe entre los dos autores. El que el espíritu de Cervantes estuviese apartado de ciertos aspectos de la Contrarreforma y del barroco resultante de ella puede también explicarse considerando de nuevo su actitud ante los libros de caballerías. La expresión "máquina mal fundada" nos da la clave: Cervantes parece estar más interesado en la estructura interior, en la "máquina", que en el efecto externo. Parece preferir un estudio estético racional de las obras en sí mismas a la censura moral. Los libros de caballerías no son para él una amenaza al bienestar religioso y social del lector, sino un problema literario.

También esta actitud tiene su tradición. El juicio del erasmista y humanista Juan de Valdés sobre el Amadís es el ejemplo más conocido:

Entre los que an escrito cosas de sus cabeças comúnmente se tiene por mejor estilo el del que scrivió los quatro libros de Amadís de Gaula, y pienso tienen razón, bien que en muchas partes va demasiadamente afetado y en otras muy descuidado; unas veces alça el estilo al cielo y otras lo abaxa al suelo, pero al fin, assí a los quatro libros de Amadís como a los de Palmerín y Primaleón, que por cierto respeto an ganado crédito conmigo, terné y juzgaré siempre por mejores que essotros Esplandián, Florisando, 
Lisuarte, Cavallero de la Cruz... los quales, demás de ser mentirosíssimos, son tan mal compuestos... ${ }^{6}$

Después de examinar varios ejemplos de buen y mal estilo en el Amadís, Juan de Valdés da las bases estéticas de una crítica total:

...los que scriven mentiras las deven escrivir de suerte que se lleguen, quanto fuere possible, a la verdad, de tal manera que puedan vender sus mentiras por verdades...?

Los factores primordiales para el crítico humanista son, pues, el estilo, la estructura y una elemental "verosimilitud". Es una manera racional y matizada que coloca al crítico y a la obra criticada en el mismo plano intelectual. Juan de Valdés no ataca desde arriba, con una serie de contrastes, al modo de Malón de Chaide, sino que intenta poner en claro las cosas, estableciendo distinciones. De esta suerte le es dado no rechazar todo el género, sino separar el Amadís del Esplandián, basándose en sus méritos individuales. Como Cervantes, Juan de Valdés percibe valores estéticos; no juzga según los efectos morales o inmorales preestablecidos ${ }^{8}$. Los autores ascéticos habrían dicho

6 J. DE VALDÉs, Diálogo de la lengua, Clás. Castellanos, 1940, pág. 168. 7 Ibid., pág. 172.

8 Luis Vives adoptó la actitud contraria, a pesar de haber participado en las mismas corrientes intelectuales que Juan de Valdés. A Vives le preocupaban mucho los efectos morales de los libros de caballerías, sobre todo de los que llegaban a España desde Francia e Italia. Bataillon resume del modo siguiente esa actitud: "Toda esta literatura la condena Vives, en la Mujer cristiana, con una severidad sin concesiones, como profundamente inmoral. En todas esas historias de amor, agradables o trágicas, el valenciano se pregunta qué es lo que puede agradar, como no sea su lado sensual. Ninguna erudición hay en sus autores, ningún cuidado de la verdad”. Aun 
que él perpetuaba los errores de las obras que criticaba. Confía en su propia percepción crítica y en su mundo, es decir, en las obras de arte que estudia.

Cervantes, como lo han hecho notar detenidamente Castro y Bataillon, debía mucho a las corrientes anteriores de pensamiento erasmista y humanista. Su "escrutinio" se asemeja, hasta en sus juicios, a las opiniones de Juan de Valdés, y son también similares las doctrinas estéticas de que se sirve:

Hanse de casar las fábulas mentirosas con el entendimiento de los que las leyeren... No he visto ningún libro de caballerías que haga un cuerpo de fábula entero con todos sus miembros...

Hablar de los gustos "neo-clásicos" de Cervantes - como lo hace Madariaga en su Guía del lector - es sólo eludir el problema. El pensamiento estético de Cervantes es algo más que una simple repetición de opiniones que habían sido comunes unos cincuenta años antes de su tiempo; debía tener raíces más profundas, puesto que fue capaz de oponer resistencia a la fuerte corriente de ideología contrarreformista. Esta originalidad se

cuando los libros de caballerías auténticos, tales como el Amadís, condenaron el desenfreno moral, "estas obras pueden regalar pasajeramente los sentidos, pero no pueden instruir el espíritu ni guiar la conducta. Es una desgracia que hayan conquistado a todo un público de ociosos, cuyo espíritu, semejante a un estómago estragado por el abuso de las golosinas, no tolera ya otro alimento" (Marcel Bataillon, Erasmo y España, México, 1950, págs. 216-217). Sin embargo, la inmoralidad que aquí se destaca es diferente por completo de la que atacaban Malón de Chaide o Avellaneda. A Vives no le preocupaba el pecado del "sueño humano", sino la posible carencia de ajuste racional y de sana relación con el mundo que puedan resultar de la lectura.

9 Quijote, I, XLVII. 
debe principalmente a que Cervantes adaptó a sus personajes la concepción postridentina de la "universalidad poética".

Como leemos en $\mathrm{El}$ pensamiento de Cervantes, una de las contribuciones de la Contrarreforma al pensamiento estético fue la doctrina de "lo universal poético". Según este concepto - consecuencia del resurgimiento y libre interpretación de la Poética de Aristóteles - al personaje u objeto representado en la obra de arte debe dársele, además de la perfección formal requerida por el Renacimiento, un fin moral. La obra artística debe ser tan ejemplar como hermosa y el lector ha de ser capaz de percibir a primera vista la posición moral de cada uno de los elementos que la componen. Las grandes comedias, fundadas, como hemos visto, en la glorificación de los valores aceptados, deben mucho a este concepto. Cervantes, a pesar de haber esgrimido su ironía en contra de esa doctrina (Sancho defiende lo "particular histórico" cuando don Quijote se pone a alabar lo "universal poético"), en el momento de crear sus personajes parece tender hacia una constancia interior, hacia un absoluto nuevo e individual. Lo que vale es la personalidad y las exigencias internas del personaje cervantino, no su tipo o "figura" ni su relación ética inmediata con la sociedad. Más que ciertas características es el ser lo que expresa lo "universal poético"; los rasgos exteriores pueden cambiar, pero por debajo de ellos hay una constancia interior, el subsuelo permanente de la personalidad. Lo permanente puede ser el destino, como en el caso del Persiles, o bien la vocación, como en el del Quijote. Cervantes crea un absoluto de significación no divina, sino humana, una especie de absoluto inmanente ${ }^{10}$.

10 No queremos dar a entender con esto que la constancia del carácter individual nunca coincide con el orden moral aceptado. El reciente estudio de Joaguín Casalduero, Sentido y forma de las "Novelas ejemplares", de- 
Esta interpretación cervantina de lo "universal poético" puede comprenderse mejor que nada por un ansia profunda de seguridad, idéntica al ansia que sentían los paladines de la Contrarreforma. En su obstinado esfuerzo por imponer la seguridad de Dios, de la totalidad, la Contrarreforma atacaba la posición individual siempre que ésta significaba relación inmanente con el mundo. Los dos modos principales como se efectuaba esta relación eran, como hemos visto, la percepción racional y la posesión voluntaria a través del amor neoplatónico con su tendencia hacia el panteísmo. El resultado de este ataque fue la llamada "escisión barroca" entre el hombre y el mundo. Pero Cervantes, después de las desilusiones de su vida y de su edad, buscaba una seguridad más difícil; afirmaba conscientemente el valor absoluto del ser individual, del "hombre de carne y hueso" de Unamuno, que se oculta detrás de las relaciones con lo circundante. Cervantes no negaba las vías renacentistas de comprensión; las subordinaba, elevando a primer plano el valor del individuo que había de aplicarlas. De este modo, aunque no siguió el camino de la Contrarreforma, el tránsito de la confianza a la conciencia fue guiado por una necesidad semejante. Cervantes sabía, por supuesto, que al asignar valor absoluto al individuo como tal, es decir, a personas de variado carácter y puntos de vista diversos, la realidad exterior adquiriría un aspecto de relatividad, como en el caso del "baciyelmo". Partiendo de esta relatividad de absolutos contradictorios, construyó su novela sobre una base problemática (método no aplicable al Quijote apócrifo, fundado todo en el único Ab-

muestra que esto ocurre con frecuencia. Sin embargo, también la divergencia es posible, puesto que el orden divino no era, como para otros autores, el principio primordial y definitivo. El sentido del yo en el carácter individual era lo que predominaba. 
soluto contrarreformista, en Dios). Lo universal poético, más que la ejemplaridad, fue lo que llevó a Cervantes a la novela.

De esta especial conciencia del problema del hombre surgieron también las sutiles diferencias entre el pensamiento estético de Cervantes y el de Juan de Valdés. Ninguno de los dos está de acuerdo con Malón de Chaide cuando ataca los libros de caballerías porque distraen la atención de las cosas divinas; ambos permanecen en el plano humano al intentar la comprensión de esos libros. Pero mientras Juan de Valdés compara valores y exige argumentos convincentes y pureza de estilo, Cervantes, como ya anticipábamos, hace una objeción más profunda. Para él los libros de caballerías falsificaban la posición del individuo y destruían así su concepto de la verdad humana. Al edificar una estructura exterior impermeable y absoluta de castillos, dragones y magos, se creaba un mundo en el cual el hombre sólo podía existir si se conformaba con él, si pertenecía a él. Era por eso imposible que el caballero andante de esas novelas se guiara por una conciencia profunda, por una necesidad de su propio ser. Cervantes criticaba el ambiente caballeresco no sólo, como Valdés, por su extravagancia e incoherencia, sino también por ser un fracaso vital, es decir, por no lograr que sus personajes tuvieran una vida interior. Los caballeros de paja, enredados como estaban en las mallas de una acción incesante y de un esquema rígido, no podían vivir - como vivían los pastores de la novela pastoril - de acuerdo con su vida interior y sus amores:

Pues ¿qué diremos de la facilidad con que una reina o emperatriz se conduce en los brazos de un andante y no conocido caballero? ${ }^{11}$

11 Quijote, Prólogo a la Primera parte. 
En lugar de que los personajes cortaran el mundo "a su medida”, el mundo los cortaba a ellos a la suya. Sólo así podemos comprender la opinión favorable que Cervantes tenía de la novela pastoril, en contraste con la que tenía de la novela caballeresca, y explicar la Galatea y los paisajes pastoriles que constituyen - sin que nos demos cuenta, muchas veces - el fondo de las peregrinaciones de don Quijote, y le conceden su peculiar libertad.

Avellaneda y Cervantes criticaban, pues, los libros de caballerías por razones diametralmente opuestas: Avellaneda, ateniéndose por completo a la ortodoxia contrarreformista, los atacaba porque fundaban un mito en el plano humano, excluyendo así el divino; Cervantes, porque la rígida trascendencia irracional de ese mito no daba cabida al valor absoluto y definitivo que para él tenía la existencia del individuo en el plano humano. Este contraste influirá en el carácter de las aventuras que cada uno invente, en el de cada personaje, en el de cada línea de sus respectivos estilos.

\section{Cervantes y la Contrarreforma}

Como la estructura divina impuesta por la Contrarreforma y la correspondiente destrucción del valor individual autónomo implicaban una limitación del mundo real, algo semejante a la ocasionada en el mundo literario por la estructura caballeresca, sería de esperar que Cervantes criticara también el aspecto restrictivo de la Contrarreforma. Es un problema difícil y muy discutido. Se trata aquí de la opinión personal, de las preferencias muchas veces inconscientes de un hombre de quien ni siquiera se tienen suficientes datos biográficos. Sin embargo, 
en las páginas del Quijote y de sus otros escritos, en las breves alusiones que de cuando en cuando hace a sí mismo y en las observaciones de sus contemporáneos sobre él, hay indicios de que no estaba enteramente de acuerdo con la ortodoxia cada vez más rígida de su tiempo.

El siguiente pasaje del prólogo a la Primera parte, pasaje sobre el que Américo Castro ha llamado la atención hace poco, revela un apartamiento más o menos consciente de las bases mismas de la técnica ascética ${ }^{12}$ :

...ni le son de importancia las medidas geométricas, ni la confutación de los argumentos de quien se sirve la retórica; ni tiene para qué predicar a ninguno, mezclando lo humano con lo divino, que es un género de mezcla de quien no se ha de vestir ningún cristiano entendimiento... ${ }^{13}$

Es éste un desafío directo, no al catolicismo ni a su dogma (Cervantes no era hereje), sino a la técnica ascética, a la constante aplicación de lo divino y eterno a lo humano y transitorio. El hecho de que relacione este "género de mezcla" con la predicación, esto es, con esa manera de presentar las cosas de modo que tengan un efecto saludable sobre el lector o el oyente, demuestra que sabía de dónde provenían todas esas nuevas restricciones impuestas al hombre. En el Quijote hay varios ejemplos de actitud irónica ante el lugar común ascético que confirman lo anterior. En un pasaje típico, Sancho está hablando de la muerte:

- No es segador, que duerme las siestas; que a todas horas siega,

12 Véase el estudio de Américo Castro, “The prefaces to Don Quijote", The Philological Quarterly, XXI, 1942, págs. 65-96.

13 Quijote, Prólogo a la Primera parte. 
y corta así la seca como la verde yerba; y no parece que masca, sino que engulle y traga cuanto se le pone delante, porque tiene hambre canina, que nunca se harta...

Dijo Don Quijote:

- Pero yo no puedo entender ni alcanzar cómo siendo el principio de la sabiduría el temor de Dios, tú, que temes más a un lagarto que a Él, sabes tanto.

- Juzgue vuesa merced... de sus caballerías - respondió Sancho-, y no se meta a juzgar de los temores o valentías ajenas; que tan gentil temeroso soy yo de Dios como cada hijo de vecino...

Y diciendo esto, comenzó de nuevo a dar asalto a su caldero, con tan buenos alientos que despertó los de Don Quijote... ${ }^{14}$

Sancho, al parecer con el consentimiento irónico de Cervantes, prohíbe que nadie se meta en lo que a él concierne, y recomienda a don Quijote que se limite a sus propios asuntos, a sus "caballerías"15. Su individualidad rechaza toda inquisición o violencia por parte de una autoridad exterior; no permite que ninguna imposición artificial de lo divino lo limite en su comunión directa con la realidad, que en este caso es el caldero. El personaje cervantino puede ser ejemplar, pero incurre en lo que para la ascética es el mayor delito, en la confianza en sí mismo.

Es evidente que sólo un autor que tuviese confianza en sí mismo podía dotar a sus creaciones de esta perspectiva de constante valor interior, y es un hecho que la vida entera de Cervantes refleja seguridad y fe en sí mismo. Los intentos de fuga en

14 Quijote, II, XX.

15 Es característico que, ante un ataque tan intelectualizado de sus actitudes o de su conducta, los personajes cervantinos contesten con gran vehemencia al crítico. La respuesta de don Quijote a don Diego Miranda es uno de tantos ejemplos. 
Argel, la promesa de componer las mejores comedias, el sereno prólogo a la Segunda parte lo atestiguan. Pero no basta recurrir a tales ejemplos; estamos ahora más interesados en el artista que en el hombre, y sería un error considerar la novela cervantina como confesión o autorretrato. Más grande que la confianza de Cervantes fue su despego, la posibilidad de trascenderse a sí mismo, que le capacitaban para comunicar su propio sentido de la vida, artística e imparcialmente, a sus personajes. ¿Qué otro escritor de la época podía haberse dicho a sí mismo: "Pasa, raro inventor, pasa adelante"? La pasmosa claridad con que se ve a sí mismo en el prólogo al Persiles, cuando describe, casi como en tercera persona, el encuentro entre él y el estudiante que lo admira, crea su propia perspectiva de valor melancólico. Cervantes se convierte en este prólogo en personaje cervantino, en criatura de proyección estética. Éste es el verdadero secreto de su creación de personajes; por medio de un despego, a veces irónico, a veces trágico, podía valorar objetivamente, como "padrastro", el significado interno de sus autoproyecciones y observar cómo vivían emancipadas de él. Pertenecen al hombre Cervantes, pero están separadas de él por el artista Cervantes.

De este modo fue capaz de rechazar con éxito los fundamentos ideológicos del barroco. En el período de la Contrarreforma, con su desengaño general, con "la trascendencia" para todos, Cervantes sometió su propio desengaño a una trascendencia personal y siguió hallando en el ser inmanente del hombre la satisfacción de su ansia de certidumbre, el verdadero objeto del arte. Esta trascendencia personal tenía el mismo propósito que la trascendencia forjada por la Contrarreforma: con ella se dominaba el panorama del mundo y se creaba una medida de valores. Sin la trascendencia, Cervantes habría caído en la impotencia y en los lamentos de un Vicente 
Espinel, quien, sabiendo que su existir íntimo lo impulsaba a cierta actitud independiente, fue sin embargo incapaz tanto de verla objetivamente como de encauzarla en forma novelística. Cervantes, con su entendimiento magníficamente visual, con su despego de todo lo que fuese sentimiento quejoso, resentimiento o frustración, fue capaz, por otro lado, de hacerse dueño, maestro y crítico de las formas y de las fuerzas creadoras. Nunca se dejó dominar ni abrumar por ellas; estaban por debajo, nunca por encima de él. Su trascendencia fue, pues, independencia y no sujeción; separaba lo humano de lo divino (sin negar ninguno de los dos), para proteger la significación del ser individual en contra del concepto oficial, que venía cristalizando lentamente, de la existencia como integrada en un sistema a la vez cósmico y social. Así, Cervantes defendió su ser y el de sus personajes contra la imposición de lo infinito con la correspondiente ruptura de la continuidad de la experiencia. Sería, naturalmente, absurdo empeñarse en que Cervantes fuese por entero independiente de todos los aspectos de la época contrarreformista. La profunda melancolía de su héroe y aun de él mismo, el problema del "ser" contra el "parecer", hasta la necesidad de definir su propio "universal poético", todo esto proviene directamente de su época y sólo a través de ella puede comprenderse. Lo único que aquí queremos sugerir es que el valor que Cervantes considera básico, la importancia que concede a la experiencia en el tiempo y la solución armónica que a veces propone, lo colocan en oposición directa a aquellos polemistas de la Contrarreforma cuya obra en fin de cuentas desembocó en el barroco. Cervantes había hallado su propia respuesta al problema, una respuesta que, como hemos visto, revalorizó en parte al Renacimiento; por otro lado, ella misma 
había de crearle dificultades - entre otras la publicación del Quijote apócrifo.

\section{La crítica Contemporánea de Cervantes}

La inmediata popularidad que en toda España alcanzó el Quijote, el hecho de que las autoridades, eclesiásticas o no, no hicieron censuras de peso a la obra, y la escasez de críticas adversas, todo parece, si no negar, por lo menos restar importancia a la oposición cervantina a los fundamentos ascéticos de la Contrarreforma. Sin embargo, si se examina de cerca lo que se ha conservado de la crítica que se hizo de Cervantes y del Quijote, se verá que su tendencia misma confirma la anterior hipótesis y nos hace comprender más la originalidad de la actitud cervantina. Únicamente el carácter recatado de Cervantes y de sus doctrinas ideológicas y estéticas - recato que hizo que no fuese reivindicado como pensador sino tres siglos después, por Américo Castro - impidió que hubiese una corriente de censura de mayor alcance y virulencia. Como veremos, uno de los factores más importantes que determinaron la creación de la versión apócrifa fue esta objetividad fundamental, esta ausencia del autor en el Quijote. En cuanto a la crítica misma, se ha estudiado relativamente poco, por ser materia naturalmente desagradable al cervantófilo. Nos limitaremos aquí a los ejemplos conocidos que se pueden aplicar al Quijote apócrifo ${ }^{16}$.

16 Francisco A. de Icaza, Miguel Herrero García y Adolfo BoNILLA Y SAN Martín han estudiado la crítica contemporánea de Cervantes y del Quijote, pero no han intentado dar una interpretación general. Las obras que contienen estos estudios son, respectivamente, El "Quijote" durante tres siglos, Madrid, 1918; Estimaciones literarias del siglo XVII, Madrid, 1930, y De crítica cervantina, Madrid, 1917. 
Cristóbal Suárez de Figueroa, escritor profesional de escaso éxito, descargó su resentimiento atacando a Cervantes y al dramaturgo Juan Ruiz de Alarcón. Aunque su pleito, en apariencia unilateral, con Cervantes pueda parecer sólo como un ejemplo más de las polémicas literarias de la época (se ha aludido con frecuencia a los celos de Suárez de Figueroa por la protección que obtuvo Cervantes del Conde de Lemos), es quizás significativo que escogiese como blanco de sus ataques a los dos autores que más se apartaban del marco ideológico del siglo. Podría ponerse en duda que Suárez de Figueroa fuera gran partidario de la Contrarreforma; sin embargo, a pesar de haber sido perseguido por la Inquisición y a pesar de su admiración por Garcilaso, tradujo varias obras religiosas, escribió novelas pastoriles que presentaban la innovación de que los protagonistas se casaban al final de la obra, y, en los últimos años de su vida, compuso el Pusilipo, obra "profundamente religiosa". Sea como fuere, su crítica de Cervantes revela que estaba suficientemente imbuido de mentalidad contrarreformista para darse cuenta de que su adversario cojeaba de ese pie.

Suárez de Figueroa tiene tres cosas concretas que reprochar al autor del Quijote:

Si es algo material, bruma a todos, abofeteando y ofendiendo con impertinencias el blanco rostro de mucho papel. Dura en no pocos esta flaqueza hasta la muerte, haciendo prólogos y dedicatorias al punto de espirar ${ }^{17}$.

(Aquí parece referirse al prólogo del Persiles, que Cervantes escribió cuatro días antes de morir.)

17 C. Suárez de Figueroa, El passagero, Madrid, 1914, pág. 21. 
Doctor. Dezís bien; mas con todo esso, no falta quien ha historiado sucessos suyos, dando a su corta calidad marauillosos realces y a su imaginada discreción inauditas alabanças: que, como estaba el paño en su poder, con facilidad podía aplicar la tijera por donde la guiaua el gusto.

Maestro. Y ¿qué fruto sacó de tan notable locura, de tan desatinada osadía?

Doctor. El que suele produzir lo que no se forja en el crisol de la cordura: mofa, risa, mengua, escarnio ${ }^{18}$.

(Esta queja va, al parecer, contra los elementos autobiográficos de narraciones como la del Amante liberal o la del Cautivo.) Por último, en la Plaza universal menciona los libros y autores más a propósito para invitar a la seducción:

No calla la fábula de Olimpia, la de Genebra, la de Isabela: halla las novelas de Bocacio, de Cintio, o de Cervantes, recita las locuras de Roldán, los desdenes de Angélica, la afición de Ruger y Bradamante, combatiendo con estos dislates lascivos las virtudes de las mujeres casadas, la castidad de las doncellas, y la preciosa honestidad de las viudas, que bien a menudo vienen a quedar violadas con tales razonamientos ${ }^{19}$.

Se ataca, pues, a Cervantes, diciendo que es impertinente, que se ocupa demasiado de sí mismo y que es un lascivo destructor de la moral. La trascendencia personal de Cervantes es para Suárez de Figueroa desvergonzado egoísmo, “confianza en sí mismo", y su defensa de la integridad individual se interpreta quizás como incitante al pecado. Hay que insistir de nuevo en

18 Ibid., pág. 95.

19 J.P. Wickersham Crawford, The life and works of C. Suárez de Figueroa, pág. 67. 
que Suárez de Figueroa representaba sólo a una pequeña minoría y que sus observaciones provenían de un motivo secundario; sin embargo, su mismo carácter demuestra que una de las posibilidades de reacción contra Cervantes partía del punto de vista ascético.

Las mismas autoridades eclesiásticas pararon mientes en Cervantes cuando en 1632 el Índice Expurgatorio del Cardenal Zapata de Sevilla eliminó una frase de la Segunda parte del Quijote. Era el primer Índice que aparecía después de 1615; dice:

Miguel de Cervantes Saavedra, Segunda parte de don Quixote, cap. 36, al medio, bórrese: "las obras de caridad que se hacen tibia y floxamente no tienen mérito ni valen nada" 20 .

Si esta supresión no es señal de una profunda reacción contra Cervantes y su obra, demuestra sin embargo con qué eficacia actuaba la jerarquía siempre que se las había con doctrinas francamente contrarias a lo ortodoxo. El Cardenal Zapata supo comprender en seguida lo que Cervantes había querido decir, supo que se trataba de un ejemplo de aquella preocupación erasmista y paulina por la oposición entre "ser" y "parecer", que era una actitud personal e interna ante el problema de la caridad y no la aceptada actitud exterior y categórica que dejaba todos los problemas de peso a la Iglesia ${ }^{21}$. La frase suprimida es,

20 Américo Castro, “Cervantes y la Inquisición”, Modern Philology, XXVII, 1929-1930, pág. 427.

21 Al referirse a esta supresión, comenta AmÉrico CASTro: "A medida que la Contrarreforma iba estrechando sus mallas, resaltaba más el peligro de afirmaciones como ésas, que en último término menguaban el valor de las obras visibles, campo sobre que actuaba esencialmente el catolicismo cada vez más desligado de cuanto afectaba el estado íntimo del individuo, 
según explica Castro, expresión excepcionalmente directa de una actitud que está en la base del Quijote. Lo que Cervantes - de acuerdo con el sistema de valores que hemos establecido para él- dice allí, es que a él no le interesa el esquema lógico de una acción, ni la idea que de ella tengan la Iglesia y los hombres. Como dice don Quijote, después de enfrentarse con los leones, la verdad no se mide sino en cuanto es creación individual, y de acuerdo con su realidad inmanente. Este criterio de verdad estaba, como veremos, en directa oposición al de Avellaneda ${ }^{22}$.

La amarga alusión de Gracián al Quijote en la Segunda

raíz de todos los peligros para la vida tradicional de la Iglesia. Sobre los hechos externos y materiales puede establecerse una unidad, un popular acuerdo, que no toleran las actitudes sutiles de las conciencias, puro matiz psicológico" (“Cervantes y la Inquisición”, pág. 430).

22 Una segunda manifestación de la reacción oficial eclesiástica contra Cervantes y sus famosos personajes se puede ver en la lámina XXIV del Erasmo y España de Marcel Bataillon. Esta lámina contiene la desfiguración que hizo un inquisidor español de un retrato de Erasmo, añadiendo las palabras "Sancho Panza y su amigo don Quijote". Si bien esta referencia se añadió probablemente a fin de ridiculizar a Erasmo y no de mostrar la conciencia que tenía el inquisidor de las tendencias erasmistas que ahora vemos manifiestas en Cervantes, no deja de ser interesante que se identifique a los dos. Refleja quizás una vaga conciencia que se tuvo en esa época de la fundamental "confianza en sí mismo" que poseían ambos personajes cervantinos y que en la España de aquella época se tenía por característica de Erasmo. Es sobre todo significativa la manera de impugnar a Erasmo. De los ojos, fuente de percepción, se han hecho dos manchas negras; la boca se ha agrandado hasta hacerla parecer de calavera; las mejillas se han oscurecido. De hecho, la cara de Erasmo se ha convertido en la de un muerto. La Inquisición, representante - como los autores ascéticos - de los aspectos más negativos de la Contrarreforma, no se contentaba con destruir las cosas que reprobaba, o con desentenderse de ellas; tenía que "deshonrar", desfigurar, quemar en público, en una palabra, desvalorizar la vida. Ponía 
parte de su Criticón es un tercer ejemplo de esta corriente de reacción contra Cervantes. Gracián está hablando de un lector de libros de caballerías:

Afeáronsele mucho y le constriñeron lo restituyese a los escuderos y boticarios; mas los autores de semejantes disparates, a locos estampados. Replicaron algunos que para passar el tiempo se les diese facultad de leer las obras de algunos otros autores que avían escrito contra estos primeros burlándose de su quimérico trabajo. Y respondióles la Cordura que de ningún modo, porque era dar del lodo en el cieno, y avía sido querer sacar del mundo una necedad con otra mayor. En lugar de tanto libro inútil (Dios se lo perdone al inventor de la estampa), ripio de tiendas y ocupación de legos, les entregaron algunos Sénecas, Plutarcos, Epictetos y otros que supieron hermanar la utilidad con la dulzura ${ }^{23}$.

Se podría pensar que el oponer obras estoicas y no ascéticas a los libros de caballerías y al Quijote significa en cierto modo que Gracián quedaba fuera de la ortodoxia contrarreformista; pero esto sería confiar demasiado en el llamado "anticristianismo” de Gracián. Hemos hablado ya de la estrecha relación que hay entre el estoicismo y la ascética, y entre el dualismo polémico de la Contrarreforma y el dualismo estilístico del conceptismo. Aunque Gracián, con su aristocracia de estilo, con su exaltación de la sabiduría individual — no del valor personal inmanente - frente al espectáculo del mundo, no era precisamente un ascético, era jesuita, y las condiciones esenciales de su estilo y de su mundo le habían sido dadas por la

el carácter en caricatura para mantener el eterno contraste. Fue una lección estilística que Avellaneda no olvidó nunca.

23 Baltasar Gracián, El Criticón, ed. Romera Navarro, Philadelphia, 1938, vol. II, págs. 35-36. 
Contrarreforma. No podía, pues, ser tolerante con los sueños, con las fuentes íntimas del valor humano, y no podía sino poner al Quijote en el mismo nivel de "necedad" que las novelas caballerescas. Para Gracián, el mundo - desde tiempo atrás separado vitalmente del hombre - no era un problema, como lo era para Cervantes, sino un espectáculo disparatado del cual a veces se podía uno fríamente aprovechar. No sorprende, pues, que se le ocultase el valor esencial del Quijote ${ }^{24}$.

Era de esperar que Gracián y otros pusieran al Quijote al lado de los libros de caballerías. Como hemos visto, la crítica que Cervantes hacía de aquellas obras se apoyaba en ideas que a los ojos de los contrarreformistas eran tan perniciosas como la literatura anterior. También era de esperar que Cervantes se hiciera cargo de la fuente y de la naturaleza de esa oposición. La insinuación de que Avellaneda era un familiar del Santo Oficio es en este sentido menos importante que el retrato del capellán de los duques. Ese eclesiástico es el más imperdona-

24 En su nota al pasaje citado, Romera Navarro afirma que Gracián no se refería a Cervantes; esta opinión me parece tan desacertada como las razones que da para apoyarla: "De referirse a él aquí, inexplicable sería la ceguedad crítica del agudísimo aragonés, y más aún cuando tenemos en cuenta su entusiasmo por el estilo de Mateo Alemán, que más se parece al estilo de Cervantes". Es natural que Gracián encomiara el estilo de Mateo Alemán, puesto que, como él mismo, el autor del Guzmán de Alfarache hacía hincapié lo más posible en la "escisión barroca" entre el hombre y el mundo, escisión que Cervantes, con su idea del valor individual, trató de armonizar. El verdadero estilo de Cervantes presenta un parecido sólo superficial con el de Alemán. - Véase la crítica, muy parecida, que hace JuAN VALLADARES DE VALDELOMAR en El caballero venturoso, 1617: "Las ridículas y disparatadas fisgas de Don Quijote de la Mancha, que mayor la deja en las almas de los que lo leen, con el perdimiento del tiempo". (Tomado de las Estimaciones literarias del siglo XVII, de Miguel Herrero García, págs. 354-355.) 
ble de los diversos "Antiquijotes" (compárese, por ejemplo, la actitud de don Diego de Miranda o la de Sansón Carrasco), puesto que él es el único que no concede nada a don Quijote, que no comprende su punto de vista, que lo ve sólo a través de su estéril y amargado dogmatismo. Lo que dice al duque y a don Quijote es un verdadero sumario de la crítica postascética de la obra cervantina:

"Vuestra excelencia, señor mío, tiene que dar cuenta a nuestro Señor de lo que hace este buen hombre. Este don Quijote, o don Tonto, o como se llama, imagino yo que no debe ser tan mentecato como vuestra excelencia quiere que sea, dándole ocasiones a la mano para que lleve adelante sus sandeces y vaciedades". Y volviendo la plática a Don Quijote, le dijo:

-Y vos, alma de cántaro, ¿quién os ha encajado en el cerebro que sois caballero andante y que vencéis gigantes y prendéis malandrines? Andad enhorabuena, y en tal se os diga: "Volveos a vuestra casa, y criad a vuestros hijos, si los tenéis, curad de vuestra hacienda, y dejad de andar vagando por el mundo papando viento y dando que reír a cuantos os conocen y no conocen" 25 .

La semejanza fundamental que hay entre esta censura y la más blanda de Mosén Valentín es que ambos gritan: “jvanidad!”, “¡mentira!”, “impertinencia!” ante ese sueño que su despierto entendimiento no alcanza a comprender. Es el mismo grito que Suárez de Figueroa y Gracián lanzaron contra Cervantes, y su origen es el mismo. Cervantes y don Quijote defendían, cada uno a su manera, el punto de vista inmediato, la significación inmanente y los impulsos y apetitos naturales del individuo, en contra de la ontología a la vez social y divina de la Contrarreforma y de la destructiva mezcla de lo divino con lo humano.

25 Quijote, II, XXXI. 
No atacaban, pero defendían los fueros vitales de su ser, y esta defensa les acarreó a ambos críticas como las que hemos visto.

La semejanza, arriba propuesta, entre la censura de Mosén Valentín y la del eclesiástico (hay cierta diferencia entre este término y el de cura de un lugar) no sólo implica que en la versión apócrifa hemos de ver a don Quijote a través de los ojos de un "eclesiástico", sino también que la crítica más acerba que se hizo de Cervantes mismo fue la de Avellaneda. Nuestra interpretación, quizás demasiado afilada, de la crítica de Gracián, de Suárez de Figueroa y del Cardenal Zapata no se justificaría si no pusieran ellos en claro gran parte del agresivo prólogo de Avellaneda, si no revelaran tanto acerca de los fundamentos humanos de todo el Quijote apócrifo. El prólogo de Avellaneda y la respuesta de Cervantes han de relacionarse con el conflicto ideológico y axiológico del siglo, si los consideramos desde este punto de vista.

\section{El intercambio de PRÓlogos}

Avellaneda establece en su prólogo una comparación entre Cervantes y él mismo, y con ello precisa nuestro problema:

En algo diferencia esta parte de la primera suya; porque tengo opuesto humor también al suyo; y en materia de opiniones en cosas de historia, y tan auténtica como ésta, cada cual puede echar por donde le pareciere... ${ }^{26}$

La oposición a que Avellaneda se refiere no será tan rotunda como la que nosotros hemos considerado aquí, pero Avellane-

26 Quijote apócrifo, pág. 6. 
da se da cuenta clara de la esencial diferencia entre él y su rival. Se hace cargo no sólo de una posible alusión ofensiva para él en el Quijote original, sino también de la antipatía personal que le inspira Cervantes. Avellaneda no estaba capacitado para percibir el desacuerdo que había entre la manera de ser cervantina y la solución ortodoxa que él debía personificar (en ese tiempo quizá nadie podía haberlo percibido), pero cada una de las ideas de Cervantes y también el modo cervantino de tratar un tema literario le irritaban muchísimo. En efecto, da a entender que el contenido "histórico" del Quijote se echó a perder con las perversas "opiniones" y con el tratamiento estético de Cervantes. La lectura misma de la versión original parece haberle causado repugnancia, y quizás fue esto lo que le impulsó a intentar una reforma de la obra. Avellaneda confirma con esto nuestra conjetura: existía entre ambos una oposición esencial de carácter y de actitud.

Más exactamente, para Avellaneda era Cervantes un viejo quejoso y descontento que todo lo veía fuera de concierto:

Y pues Miguel de Cervantes es ya de viejo como el castillo de San Cervantes, y por los años tan mal contentadizo, que todo y todos le enfadan... ${ }^{27}$

Pero disculpa los yerros de su Primera parte, en esta materia, el haberse escrito entre los de una cárcel; y así no pudo dexar de salir tiznada dellos, ni salir menos que quexosa, murmuradora, impaciente y colérica, cual lo están los encarcelados ${ }^{28}$.

El problema más interesante no es el motivo sino la tendencia, el contenido de estas observaciones. Cervantes, que había

27 Ibid., pág. 5.

28 Ibid., pág. 6. 
creado a Cipión y Berganza con su constante "no murmures", que insistía en alabar a los autores de su tiempo (llega hasta a loar a Suárez de Figueroa en uno de los últimos capítulos del Quijote), aparece en esta descripción extrañamente desfigurado. No sería fácil comprender a primera vista por qué la misteriosa ofensa a Lope de Vega y a Avellaneda de que éste habla debía dar lugar a tan extraño juicio. Pero si se compara el retrato que hace Avellaneda de Cervantes con el que hace Suárez de Figueroa la situación se aclara en seguida. La semejanza es sorprendente. Para ambos lo que aleja a Cervantes del marco ideológico de su tiempo no es sino el descontento o la desvergüenza. Rebajan su estética al nivel del capricho personal. Su crítica humanística de la comedia se considera sólo explosión de mal humor. En suma, no supieron ver otro motivo para la confianza cervantina en sí mismo que el rencor. Sea cual fuere la causa original del ataque a Cervantes, es ese "opuesto humor al suyo" lo que determina la relación entre ambos.

Este conflicto, no sólo de personalidades sino también de visiones de la vida, tuvo extrañas consecuencias: por un lado la aparición misma de ese libro que, por ser de "opuesto humor", más que Quijote apócrifo debiera llamarse "Anti-Quijote"; por el otro, una serie de alusiones directas a Cervantes, aun más acerbas y rencorosas que el citado análisis de su personalidad. Cervantes, dice Avellaneda,

...como soldado tan viejo en años cuanto moço en bríos; tiene más lengua que manos ${ }^{29}$.

29 Ibid., pág. 5. Es interesante que Gracián, hablando de la relación entre los defectos físicos y los de carácter, pueda decir: “...faltan los mancos en la perfección de las obras, en hacer bien a los demás” (El Criticón, Primera parte, Crisi IX). Si esto se considerara prejuicio general, explicaría hasta cierto punto la alusión increíblemente injusta a la herida de Cervantes. 
En seguida se complace malignamente en imaginar que quizás pueda quitarle a Cervantes la ganancia de la verdadera Segunda parte, de la cual en aquella época no existían probablemente sino los dos tercios; por último, insinúa que Cervantes era cornudo. Con esto último parece haberse agotado su almacén de invectivas.

La implacable dureza de este ataque, su descarada indecencia, parecen provenir de raíces aun más profundas en el alma de Avellaneda que la divergencia puramente temperamental y filosófica. Existía quizás alguna frustración, alguna imperfección psicológica. Se ha aludido ya a la íntima relación que existe entre el ascetismo y la separadora pasión del odio, que tanto contrasta con la unión neoplatónica por medio del amor; y esto puede ser de importancia decisiva aquí. No cabe duda de que el antagonismo producido por un eterno dualismo en algunos de los partidarios de la Contrarreforma se tradujo en odios y resentimientos personales. El mundo que para ellos no era sino "ponzoña" forzosamente tenía que contagiarlos. La actitud ascética, que consistía en concentrarse en las cosas del mundo evitando a la vez todo contacto vital con ellas, tenía que dar lugar a un sinnúmero de frustraciones individuales, y éstas a un odio que se iba acumulando poco a poco hasta llegar a un punto en que el más nimio incidente lo hacía desbordar. De este modo, la gigantesca polémica de la Contrarreforma se reflejaba en miniatura en las polémicas individuales de sus partidarios. Fue una época de tremenda irritabilidad. A Francisco Suárez, por ejemplo, lo persiguieron toda su vida con enconados ataques personales, quizás precisamente porque era capaz de hallar refugio trascendental en la serenidad de su propio neoescolasticismo. La actitud de Avellaneda hacia Cervantes, lo mismo que su actitud ante los libros de caballerías, cobra un 
sentido posible, si se la considera a la luz de la Contrarreforma. Se percibe en el prólogo esa dureza extrema y esa invulnerabilidad que tanto deploraba el don Quijote original en su réplica al eclesiástico ${ }^{30}$.

Hay que repetir que estas consideraciones no pretenden ser una acusación de la Contrarreforma en general, ni quieren dar nueva vida a la "leyenda negra" de España. La riqueza artística del Siglo de Oro español, su color, su movimiento, su libertad harían absurdo cualquier ataque de este tipo. Sin embargo, como hemos visto, los "monstruos" de la literatura del siglo XVII fueron un producto más indirecto que directo de la ofensiva ideológica. Los artistas, como individuos, ya estuviesen apartados del contacto vital con el mundo, ya arrancados de su propia posición en la sociedad, bien podían escribir obras teatrales casi trágicas y, además, aprovechar en la presentación de ellas las nuevas posibilidades de color y movimiento. Cada uno se apartó a su modo, no de la ortodoxia, sino de los resultados de ella, es decir, de la identificación del individuo con la organización y la burocracia social. Y este apartamiento constituía un estímulo para la producción artística individual. En cambio, aquellos propagadores de la Contrarreforma que con su pesimismo y sus

30 Hay en el prólogo de Avellaneda un rasgo más que podría interpretarse como reacción contra el de Cervantes. La parodia de los "latinicos" de la erudición superficial, cosas ambas que para Cervantes no eran sino ademanes con que se pretendía encubrir el vacío del entendimiento, debe haber sido uno de los rasgos del prólogo original que a Avellaneda le parecieron petulantes y agresivos. Estos valores eran sagrados dentro de la concepción formal que de la erudición tenía Avellaneda y él tuvo cuidado de afirmarlos insertando en su prólogo un pequeño corpus de citas eruditas. Esgrime en su defensa a Santo Tomás de Aquino, a San Gregorio y a ambos Testamentos, en contra de la ironía de Cervantes, y con ello vuelve a "mezclar lo humano con lo divino". 
ataques habían arrancado al hombre de su idílica visión pastoril del mundo, y aquellos otros que los seguían y que aceptaban por entero la nueva jerarquía de valores, no tenían necesariamente esas cualidades; al hacer experimentos con el virus del odio, ellos mismos quedaban con frecuencia contagiados.

La reacción de Cervantes ante la ofensiva de Avellaneda casi podía preverse. Encasillado en su trascendencia personal, Cervantes no era hombre que se dejase arrastrar a polémicas y se rebajase a represalias. Al contrario, se esforzó por lograr una armonización irónica de la obra de Avellaneda con la suya. Era una técnica de aprovechamiento más que de ataque. Así Cervantes dejaba a Avellaneda solo con su responsabilidad:

Quisieras tú que lo diera del asno, del mentecato y del atrevido; pero no me pasa por el pensamiento: castíguele su pecado, con su pan se lo coma y allá se lo haya ${ }^{31}$.

No debe interpretarse esto como indiferencia por parte de Cervantes; estaba profundamente interesado, como nos lo demuestran los capítulos que siguen al LVIII, pero su táctica era cervantina. Hay, en primer lugar, una afirmación del ser, de la significación de lo personal, en un tono que se asemeja mucho al de la réplica de don Quijote al eclesiástico:

Lo que no he podido dejar de sentir es que me note de viejo y de manco, como si hubiera sido en mi mano haber detenido el tiempo, que no pasase por mí, o si mi manquedad hubiera nacido en alguna taberna, sino en la más alta ocasión que vieron los siglos pasados, los presentes, ni esperan ver los venideros... y hase de advertir, que no se escribe con las canas, sino con el entendimiento, el cual suele mejorarse con los años. He sentido

31 Quijote, II, Prólogo. 
también que me llame envidioso, y que, como a ignorante, me describa qué cosa sea la invidia; que, en realidad de verdad, de dos que hay, yo no conozco sino a la santa, a la noble y bien intencionada... 32

De este modo se arranca de la carne las espinas.

Hasta este punto no ha habido reacción ofensiva visible; pero una vez afirmada su propia personalidad, puede proceder al aprovechamiento artístico e irónico. Primero hay una alusión a la "ocupación continua y virtuosa" de Lope; en seguida, las dos anécdotas del loco y los perros, que sugieren la perversidad, el sadismo y la falsificación artística que Cervantes encuentra en su rival. Constituyen, en efecto, todo un juicio crítico de la versión de Avellaneda. Pero la última y más irónica maniobra consiste en incluir el Quijote apócrifo en su Segunda parte, haciendo que sus personajes lo critiquen despiadadamente. Cervantes ya había utilizado la Primera parte del Quijote de manera semejante, al principio de la segunda, con el objeto de subrayar la realidad personal inmanente de don Quijote y de Sancho y contrastar esta realidad carnal con su marco anterior de existencia literario o típico. Ahora es la versión de Avellaneda la que va a desempeñar ese papel, aunque de modo mucho más ridículo. Así, cuando le hablan de las "cosas obscenas y torpes” que hay en el libro, don Quijote observa: "Retráteme el que quisiere, pero no me maltrate". Por otro lado, don Álvaro Tarfe — imitado por Cervantes como represalia irónica - le describe a Sancho la imitación que de él se hizo:

¡...más gracias habéis dicho vos, en cuatro razones que habéis hablado, que el otro Sancho Panza en cuantas yo le oí hablar, que

32 Loc. cit. 
fueron muchas! Más tenía de comilón que de buen hablador, y más de tonto que de gracioso ${ }^{33}$.

Don Quijote y Sancho hacen entonces que don Álvaro declare oficialmente la autenticidad de ambos, y añade Cervantes:

...quedaron Don Quijote y Sancho muy alegres, como si les importara mucho semejante declaración y no mostrara claro la diferencia de los dos don Quijotes y la de los dos Sanchos sus obras y sus palabras ${ }^{34}$.

El último golpe lo asesta Cide Hamete Benengeli cuando llama a Avellaneda "presunto y malandrín historiador", epíteto que viene a compensar al lector por todos los no dichos en el prólogo. De este modo, Cervantes rodea a Avellaneda, lo armoniza irónicamente con su propia creación, lo pone en ridículo, pero nunca le concede el honor de una polémica.

Por más capaz que Cervantes fuera de defenderse contra ataques de los demás, no podía permitir que una personalidad extraña se interpusiera entre él y sus personajes. De ahí el esfuerzo por distinguir la realidad de don Quijote y Sancho de la falsedad de su imitación. Es un esfuerzo por posesionarse de nuevo de su propia esencia, esencia real en sí misma e independiente de la impresión que pueda causar en los demás. No podía permitir que se confundiera su ser, reflejado en sus personajes, con el parecer, porque ésa sería una afrenta no sólo a su personalidad, sino también a su trascendencia personal, a la esencia de su existir artístico:

33 Quijote, II, LXXII.

34 Loc. cit. 
Para mí solo nació Don Quijote, y yo para él: él supo obrar, y yo escribir; solos los dos somos para en uno, a despecho, y a pesar del escritor fingido y tordesillesco, que se atrevió, o se ha de atrever, a escribir con pluma... mal adeliñada las hazañas de mi valeroso caballero... ${ }^{35}$

El remedio que usó Cervantes contra la usurpación de su ser debe haber sido tan doloroso como la herida original. Don Quijote no sólo no llega a las justas de Zaragoza, privando con ello al mundo de una estupenda aventura, sino que debe morir, como una última afirmación de su independencia. A diferencia del pícaro y del caballero andante, que voluntariamente se entregan a cualquier autor que les prometa una existencia prolongada, Cervantes insiste en que don Quijote es víctima de una muerte real y por tanto irrevocable:

...te doy a don Quijote dilatado, y, finalmente, muerto y sepultado, porque ninguno se atreva a levantarle nuevos testimonios... ${ }^{36}$

$\mathrm{Al}$ introducirse en el eje espiritual que une a don Quijote con Cervantes, al meterse desastradamente en el hueco de sus armaduras, Avellaneda echó sobre sí una grave responsabilidad. Quizás don Quijote haya tenido que morir por otros motivos de más peso que la posibilidad de futuros Avellanedas, pero toda intervención en la muerte del Caballero equivale a una complicidad en la muerte de la significación del hombre sobre la tierra.

Así, pues, de la larga batalla de la Contrarreforma con el hombre inmanente, con su experiencia, su amor y su confian-

35 Quijote, II, LXXIV.

36 Quijote, II, Prólogo. 
za en sí mismo, es un símbolo este combate singular entre los dos Quijotes. Para nosotros los cervantófilos, no era una escaramuza aislada, sino una prueba decisiva, una cristalización de ideologías opuestas.

Por supuesto, es evidente que el identificar a Avellaneda tan absolutamente con la polémica de la Contrarreforma, por más útil que sea para determinar la posición elemental de los dos hombres y de las dos novelas, no puede constituir realmente una explicación definitiva. Si la Contrarreforma exigía cierta conformidad ideológica y artística del individuo, no trató siquiera de restaurar el anonimato artístico de la Edad Media. Como hemos visto, los estilos barrocos son frecuentemente el resultado de una acentuación de la individualidad del artista al perder éste el contacto horizontal de su espíritu con el mundo. Por ello, un simple esbozo general de las diferencias entre Avellaneda y Cervantes es insuficiente. A pesar de toda su ortodoxia, el Quijote apócrifo no es un tratado ascético, sino una novela, y en ella podemos hallar el testimonio de la confrontación individual de Avellaneda con su mundo. Pero antes de adentrarnos en el estilo y la trama de la novela, debemos saber algo de la visión de Avellaneda, de su actitud no sólo ante la vida y el hombre, sino también ante su problema inmediato, ante el Quijote que él se propuso continuar. 



\section{AVELLANEDA Y EL QUIJOTE}

\section{LA TÉCNICA DE REINTERPRETACIÓN}

¿Por qué continuó Avellaneda el Quijote original y en qué medida lo imitó? Es evidente que la respuesta a estas preguntas no la encontraremos ni en el tan discutido rencor personal de Avellaneda contra Cervantes, ni tampoco en la profunda antipatía ideológica y vital que, como hemos visto, determinaba las relaciones entre los dos. El mismo Avellaneda, a pesar de su expreso designio de quitar a Cervantes la ganancia de su Segunda parte, debe haber sido que una imitación tenía más de lisonja que de venganza. El que Avellaneda se dedicara a ese trabajo significa que su opinión del Quijote no era tan negativa como la que tenía de Cervantes. Si insistimos, pues, en el fundamental contraste humano entre Cervantes y Avellaneda, el hecho mismo y el método de la imitación se tornan problemáticos.

La historia literaria del Quijote nos ayudará a poner en claro el sentido de la distinción que Avellaneda establecía entre Cervantes y su obra. Más de una vez se ha observado que no hay en el Quijote fronteras ideológicas precisas; las ideologías y la vida son relativas: de ahí el fracaso del crítico que intenta abordar la obra desde un solo ángulo. Hay, en efecto, tan escasa insistencia en una determinada enseñanza y en cambio es tan vigorosa la tendencia a armonizar sistemas contradictorios de valores por medio de la confianza implícita en el valor definiti- 
vo del individuo, que cada generación de lectores ha sido capaz de sacar de la obra sus propios ideales artísticos, de hallar en ella sus propios problemas y preocupaciones. Esta flexibilidad es, naturalmente, uno de los factores básicos que determinan toda obra maestra. Siempre que en el Quijote se da una respuesta fija y puramente contemporánea al problema humano, como, por ejemplo, en el caso del eclesiástico, no es sino la opinión de un solo personaje, y muchas veces se halla contrastada irónicamente con el punto de vista opuesto. De este modo, los críticos del Quijote han quedado en libertad de identificar el libro con sus aspiraciones personales. Ha sido ése el fenómeno característico de la existencia histórica de la obra. Unamuno ve en ella su propio sentido trágico de la vida; los románticos, la gloria del idealista individual; los "filósofos" franceses, el predominio de la razón práctica, encarnada en el gobierno de Sancho Panza. En relación íntima con esta usurpación vital del Quijote, está el hecho, igualmente característico, de que a Cervantes se le han negado sus propios fueros de autor. Como las pocas opiniones directas de Cervantes (expresadas, por ejemplo, en los prólogos) no coincidían por lo común con las de sus lectores, se llegó a la conclusión de que Cervantes no comprendió su propia obra. Se le supuso poseído por una especie de genio infantil; tuvo que aparecer El pensamiento de Cervantes para acabar con esta injusticia.

La imitación de Avellaneda, con el ataque a Cervantes en el prólogo, es, pues, el primer ejemplo de esta separación entre la obra y el autor, ejemplo que se presenta en el momento mismo de nacer el Quijote. Avellaneda revela el modo como distingue entre su modelo y el autor cuando se refiere a los "yerros de su Primera parte", o en el pasaje ya citado: 
En algo diferencia esta parte de la primera suya; porque tengo opuesto humor también al suyo; y en materia de opiniones en cosas de historia, y tan auténtica como ésta, cada cual puede echar por donde le pareciere... ${ }^{1}$

Se habla aquí del contenido de la novela como si se tratara de un hecho histórico, que Cervantes vino a echar a perder con sus errores y deformaciones. Si Avellaneda quería apropiarse del Quijote, debía primero poner en duda la creación del autor original. Este empeño es a su manera comparable al de Unamuno en su Vida de Don Quijote y Sancho, cuando altaneramente llama a Cervantes "historiador" o en otro lugar "genio temporero".

La actitud crítica de Avellaneda ante el Quijote, la base de su técnica de reinterpretación, quedó ya señalada arriba, cuando intentábamos clasificar el género. El concepto de la novela como género artístico justificado en sí mismo no se aceptó antes del siglo xIX; así, tanto Avellaneda como Cervantes hubieron de enfrentarse al grave problema de la terminología crítica. Son significativas las soluciones de cada uno. Avellaneda concebía la novela como una "historia" imitada, y por eso trataba de narrar los hechos de acuerdo con sus causas y consecuencias, de insistir en lo verosímil de la realidad por él inventada. En cambio, a Cervantes lo que le interesaba era la elaboración artística (técnica de "yerros" y "opiniones”, según Avellaneda); para él la novela era una manera de sobrepasar los límites de los géneros:

Porque la escritura desatada destos libros da lugar a que el autor pueda mostrarse épico, lírico, trágico, cómico, con todas aque-

1 Quijote apócrifo, pág. 6. 
llas partes que encierran en sí las dulcísimas y agradables ciencias de la poesía... ${ }^{2}$

Así, pues, donde Cervantes hallaba libertad de expresión y organización, libertad de crear desde dentro valores vivos humanizados, Avellaneda no veía sino una historia, una realidad mundana desnudada de mito por las polémicas espirituales del pasado; en suma, una mera sucesión de acciones humanas. La poesía de Cervantes se hace prosa en Avellaneda.

Sin embargo, no le bastaba a Avellaneda el simple esqueleto de una historia; había que hacerlo bailar de modo que fuera a la vez ameno e instructivo. Su libro, insiste Avellaneda, "no enseña a ser deshonesto, sino a no ser loco" ${ }^{3}$. Además, como hemos visto, Avellaneda ha de tomar muy en serio el ataque a los libros de caballerías. Parece creer que Cervantes quiso reducir a lo "particular histórico" un pernicioso concepto de lo “universal poético", y se propone entonces llevar más allá este impulso. Aun más, la base de la objeción original de Avellaneda al Quijote debe haber sido el hecho de que, después de destruir el mito caballeresco, Cervantes no afirmó lo bastante un sustituto divino. Debió concebir el Quijote como una novela picaresca especializada que carecía de la tradición ascética tan evidente en el Guzmán de Alfarache y en el Buscón. Cuando Gracián dijo que leer el Quijote era "dar del lodo en el cieno", se refería probablemente a esa carencia de "instrucción”. Ya hemos visto el remedio de Avellaneda: no valora los libros de caballerías, los condena y luego los sustituye por la Guía de pecadores y por el rosario.

En cuanto al aspecto exterior del entretenimiento, Avella-

2 Quijote, I, XLVII.

3 Quijote apócrifo, pág. 5. 
neda, alentado por el nuevo interés con que el espíritu didáctico de la Contrarreforma se vuelve hacia Horacio, se propuso escribir no sólo una historia, sino una historia cómica: "Como casi es comedia la historia de don Quijote de la Mancha, no puede ni debe ir sin prólogo..."4. Aquí de nuevo se halla reflejado cierto juicio crítico del modelo. Avellaneda se hacía cargo perfectamente de que, a pesar de lo imperfecto de la polémica cervantina, el Quijote original había tenido un éxito abrumador en todas las clases sociales, como obra de regocijo y comedia, y se propuso aprovechar esta circunstancia. Lo mismo se les ocurrió a otros autores, y se hicieron lugar común las caricaturas que acentuaban los aspectos cómicos, las extravagancias exteriores de don Quijote y Sancho. El absurdo don Mendo del Alcalde de Zalamea es quizás el mejor ejemplo conocido. Si hemos de creer las teorías de Bergson sobre la risa, el hecho mismo de que el Quijote impresionaba sobre todo por su comicidad implicaba que sus personajes habían de convertirse en tipos existentes sólo como apariencia exterior, es decir, incapaces de conciencia verdadera o de voluntad independiente. Quevedo, que dice haber leído a Cervantes con "temor y reverencia”, es, según parece, el único hombre de su tiempo que percibió los abismos escondidos bajo la superficie del arte cervantino. El Quijote apócrifo nos hará ver que Avellaneda no los percibió.

Avellaneda, quizás dominico y seguramente eclesiástico y

4 Quijote apócrifo, pág. 5. Mariano Baquero Goyanes, en un artículo reciente ("La novela y sus técnicas", Arbor, junio de 1950), interpreta el uso del término "comedia" por Avellaneda como alusión al abundante diálogo del original. "Comedia", por lo tanto, no significa ni más ni menos que el drama predominante de la época. Halla confirmación a su tesis en OrTEga, "Adán en el paraíso". Sin embargo, en Meditaciones del Quijote, 18, OrTEGA se inclina por la interpretación nuestra. 
representante activo de la Contrarreforma, concebía, pues, el Quijote como historia cómica, como medio de pasatiempo e instrucción, o, mejor dicho, de destrucción. Sólo fue capaz de ver la cobertura formal narrativa de una obra que contenía las esencias espirituales de lo épico, lo trágico, lo lírico y lo cómico, y que, sobrepasando creadoramente las fronteras de los géneros, era verdaderamente autónoma. Quizás Avellaneda no tuvo ojos para ver al héroe épico, para comprender el valor inmanente al loco, no sólo por su aparente sumisión a los factores más estériles de la ortodoxia, sino también por ser aragonés. La épica española, la exaltación espiritual de la reconquista, había sido ante todo castellana, y el Cervantes de Lepanto, a pesar de su ironía, nunca escatimó el valor de esa exaltación. Como él mismo decía, estaba escribiendo un poema épico en prosa. Avellaneda, en cambio, sólo se interesaba por lo que en las armas y en la guerra era táctica y organización, e incluyó en el Quijote apócrifo frecuentes disertaciones sobre temas como el uso de la artillería o la función de la inteligencia militar. El espectáculo de la valentía no podía producir en él temor ni reverencia como en el castellano Quevedo; siguiendo, al parecer, los métodos políticos de su reino, estaba más interesado en los objetivos y en la técnica con que se podían alcanzar ${ }^{5}$. Para un aragonés, posiblemente era locura absurda el valor justificado en sí mismo; para un partidario de la Contrarreforma, no cabe duda de que era un pecado mundano, un "castillo en el aire". Avellaneda y otros de su tiempo se detuvieron, pues, en una superficie del Quijote, creada por ellos mismos, por su propia

5 El Testamento de don Quijote de Quevedo nos presenta un don Quijote en cierto modo tan deformado como el de Avellaneda. Pero Quevedo tuvo cuidado de conservar el valor del héroe e insistir en él. Fue allí donde se dio cuenta de que había una significación por debajo de la superficie. 
interpretación; con esto forzosamente debían separar a Cervantes de su obra. En los prólogos, en las afirmaciones acerca de sí mismo, Cervantes había revelado, por lo menos parcialmente, la verdad acerca de su posición. De este modo Avellaneda podía estimar el Quijote y a la vez denostar al autor que, en cierto modo, lo había amenguado y pervertido.

\section{LA HERENCIA DE LA IMITACIÓN}

Menéndez Pidal ha sido uno de los primeros en observar que en la historia de la literatura castellana se hace manifiesta una curiosa repugnancia a considerar la obra individual como producto o propiedad exclusiva de su creador ${ }^{6}$. Es natural que sucediera esto en la Edad Media, cuando al artista le preocupaba la tradición épica nacional y popular, cuando se concebía al hombre - héroe o poeta - ya como representante de la especie humana, ya como individuo. Ha quedado para los filólogos modernos la tarea de descubrir las versiones originales de los poemas épicos. Esta tradición medieval de dar más importancia a la "extensión" o relación con el lector que a la "intención" o relación con el artista ${ }^{7}$ continuó más tarde en los libros de caballerías y en la comedia. Ambos géneros van dirigidos al pueblo; hay sin embargo, a este respecto, cierta diferencia entre ellos: el primero se imprimía para el lector individual, mientras que el segundo, como ya decía Tirso, se representaba ante un público y éste bien podía comprender todas las clases sociales,

6 Véase el artículo "Quelques caractères de la littérature espagnole", Revue Internationale de l'Enseignement, LXX, 1916, págs. 401-413.

7 Estos términos, utilísimos, se encuentran en el ya citado libro de AUgusto Centeno. 
como el de los poemas épicos. De este modo la comedia podía, en cierto sentido, continuar la tradición épica, revisando versiones anteriores, convirtiendo una unidad en otra; los libros de caballerías, en cambio, eran imitados en largas series de novelas. Sólo el hecho de aparecer en forma impresa pudo salvar al Amadís de esa cuasifusión - típica de la comedia - con sus lectores. La aparición de la imprenta modificó, pues, la tendencia española a separar la creación de su autor. Las energías que antes se dedicaban a la tarea de cambiar y reelaborar parecían emplearse ahora, salvo en el caso de la comedia, en continuar e imitar.

Este nuevo cauce de energías no sólo afectó a las novelas caballerescas, sino también a obras como la Celestina, el Lazarillo y el Guzmán de Alfarache. Pero como estas obras albergan una creación personal más profunda, las versiones posteriores aparecían con cierta vacilación y por lo común se las consideraba diferentes e inferiores. La nueva tendencia hacia la autonomía artística fue, por supuesto, más marcada en el caso de la lírica del siglo XVI. Los géneros renacentistas de novela y lírica, que se iban formando lentamente, casi por definición tenían dificultad en adoptar una costumbre que provenía del meollo oral y popular de las tradicionales formas épico-dramáticas castellanas.

Cuando la Contrarreforma comenzó su larga polémica contra la confianza del individuo en sí mismo, contra su personalidad creadora, hubo de oponerse, naturalmente, a las manifestaciones líricas y novelísticas de esa personalidad. Hemos visto ya varias alusiones adversas a Cervantes; el ataque contra Garcilaso y las obras pastoriles fue aún más acerbo ${ }^{8}$. Pero como a los hombres de la Contrarreforma les interesaba tanto la re-

8 Reacción típica es la de MALón de ChaIde en su introducción a La 
construcción como la destrucción, esta hostilidad inicial originó muy pronto varios intentos de volver a escribir las obras a lo divino. Sólo penetrando de este modo en la esencia creadora, la costumbre nacional de imitar y continuar las obras literarias pudo extenderse plenamente al campo, antes hermético, de la novela y de la lírica. Al individuo se le hizo "caer en la cuenta”, y otro tanto se hizo con las grandes obras literarias del pasado. Lo único que se conservaba de Boscán, Garcilaso, Montemayor y otros en las nuevas versiones era el aspecto formal; la inmanencia de su presencia estilística personal se había sustituido por un renovado concepto de la trascendencia?

Cuando la Contrarreforma, cargada de intención, dejó gradualmente campo libre al barroco, con su seguridad y autosuficiencia; cuando el concepto del arte como fin en sí mismo comenzó a sustituir el concepto del arte como medio de reforma, la tendencia a basarse en modelos anteriores se generalizó plenamente. No se trataba ahora de servirse de determinadas obras como vehículos para el mensaje de la Contrarreforma, sino de emplear los modelos anteriores como trampolín que los disparase hacia nuevos estilos y a una autonomía más aguda y más terrible que ninguna conocida hasta entonces. No se trataba siquiera de reformar un género determinado. Las distinciones de géneros, fundamentales en la estructura crítica del Renacimiento, quedaron aniquiladas ante el alud de los nuevos estilos. Exceptuando algunos pocos casos, tales como

conversión de la Magdalena, pues dice: “CCómo se recogerá a pensar en Dios un rato la que ha gastado muchos en Garcilaso?"

9 La importancia de esta intervención de la Contrarreforma en obras profanas de la literatura ha sido subrayada hace poco por Dámaso Alonso a propósito de la influencia que tuvo el Garcilaso reformado por Sebastián de Córdoba en la poesía de San Juan de la Cruz. Véase La poesía de San Juan de la Cruz, Madrid, 1942. 
los Sueños y el Criticón, ni los escritores del barroco ni los de la Contrarreforma fueron capaces de crear formas ni géneros literarios originales. Para lograr esto habría sido necesario la confianza en la capacidad del individuo para conquistar con el arte su mundo inmanente. Los escritores ascéticos se basaban en los tratados estoicos y en el Libro de Job; Góngora continuaba formas y metros inventados antes de su tiempo; Quevedo y Mateo Alemán renovaron la novela picaresca; Calderón nunca se apartó del género tal como lo había inventado Lope. Estas formas fueron elaboradas, se les dio color y movimiento, se les infundió una sensibilidad estilística nueva, pero eran el punto de partida, más bien que el fin deseado, del proceso creador.

¿A qué tipo de imitación pertenece el Quijote apócrifo? Sólo indirectamente se halla relacionado con el primero, es decir, con la revisión épica en manos del pueblo, o la reelaboración dramática para adaptarse a nuevos gustos populares. Pero como hemos visto, uno de los factores más importantes que impulsaron a Avellaneda a apropiarse del Quijote fue la popularidad de la obra. No se trataba tampoco de una continuación inofensiva, casi inocente, como los Lazarillos y las Dianas, por más que Avellaneda se justificara aludiendo a esos precedentes:

...sólo digo que nadie se espante que salga de diferente autor esta Segunda parte, pues no es nuevo el proseguir una historia diferentes sugetos. ¿Cuántos han hablado de los amores de Angélica y de sus sucesos? Las Arcadias, diferentes las han escrito, la Diana no es toda de una mano ${ }^{10}$.

No, el Quijote apócrifo no tiene de común con estas continuaciones sino el hecho de la usurpación. El ataque a Cer-

10 Quijote apócrifo, pág. 5. 
vantes, la necesidad misma de hacer referencia a imitaciones anteriores ponen de manifiesto que había un propósito distinto.

Fuera de esto, y aunque parezca sorprendente después de lo que hemos venido diciendo, el Quijote apócrifo no fue enteramente un Don Quijote “puesto a lo divino”. La nueva polémica, teñida de ascetismo, en contra de los libros de caballerías, el deseo de alejar la obra original de la jurisdicción, al parecer demasiado indulgente, de Cervantes, el ingenuo afán de intensificar las posibilidades de instrucción, todo esto atestigua el intento de poner a un lado los elementos profanos. Sin embargo, si por un lado Avellaneda alberga tan devotos propósitos, por el otro daba cabida en su obra a la obscenidad y presentaba las fuerzas de la sociedad como algo vigoroso y muy loable. Por todas partes saltan a la vista los asuntos religiosos y los lugares comunes de la Contrarreforma; pero el celo contrarreformista no parece haber sido sino uno de los factores determinantes de la imitación. Sólo en los momentos en que el retablo hace posible una advertencia o un consejo es cuando Avellaneda aduce modelos ascéticos. Se trata aquí, al parecer, de una reminiscencia consciente, provocada intencionalmente; como veremos, el libre flujo de su creación producía estilos e ideas del todo distintos. Para dar un ejemplo, la interpretación ascética del Quijote aparece ante todo en pasajes de autocrítica, en los que Avellaneda habla de aquello que debió haber escrito, no de lo que escribió. Aunque ya la introducción confirma esta idea, el último párrafo de la obra es aún más curioso; en él Avellaneda parece darnos un anticipo de sus planes para un tercer volumen. Entre otras cosas alude a un caballero de sexo femenino:

Llevóla el buen caballero sin saber que fuese muger, hasta que vino a parir en medio de un camino, en presencia suya, dexán- 
dole sumamente maravillado el parto, y haziendo grandísimas quimeras sobre él: la encomendó, hasta que volviese, a un mesonero de Valdestillas; y él, sin escudero, pasó por Salamanca, Ávila y Valladolid, llamándose el Caballero de los Trabajos... ${ }^{11}$

Fuera de lo grotesco de tal incidente, el nuevo apodo, "Caballero de los Trabajos", pone a don Quijote plenamente dentro de la tradición ascética, que concibe al mundo como prueba y al cielo como recompensa. Pero una identificación tan absoluta con la ascética, con la idea de la miseria y ficción del mundo, implicaría un Quijote enteramente nuevo; sus actos surgirían en un nuevo nivel: el didáctico, y su expresión estaría basada en una jerarquía de valores enteramente distinta. Sería un don Quijote capaz de existir no sólo sin Dulcinea - como lo es el Quijote de Avellaneda-, sino también sin Sancho; sería un solitario, poseído por el terrible reconocimiento de la soledad, herencia común de Job y del "pícaro".

Estos valores ascéticos existen en el Quijote apócrifo, y de ellos está compenetrado su protoplasma esencial; sin embargo, no son ellos los que determinan la relación entre el modelo y la imitación. Es cierto que emergen de cuando en cuando a la superficie de la historia, pero probablemente el motivo inmediato para la imitación fue la esterilidad de Avellaneda, su incapacidad de forjar formas artísticas y de dar vigor al movimiento narrativo. El dejar intactos la estructura peripatética, el título, los tipos fundamentales y varios aspectos particulares de estilo, el continuar, sobre todo, la técnica cervantina de preparar las aventuras atestiguan su pobreza de invención. El Quijote original dio, pues, lugar a un impulso de literato, fue productor de un estilo; no se trataba tanto de reformar a Cervantes como

11 Quijote apócrifo, pág. 302. 
de aprovechar en el Quijote los modelos de su ímpetu creador. Como antes hemos dicho, se conserva cuidadosamente lo que en Cervantes es corteza, mientras se pasa por alto o se rechaza a Cervantes mismo. Se inyecta en la sangre del original una nueva solución de personalidad, valor y estilo. Más que revivir o reformar el Quijote, le importaba a Avellaneda embalsamarlo. Así pues, al usar el modelo como marco formal de una reinterpretación estilística y no moral, el Quijote apócrifo corresponde, en cierto modo, a la tercera tradición barroca de imitación. La posible objeción de que los préstamos barrocos por lo común se atenían mucho menos al original, plagiaban menos, eran más auténticamente creados y alcanzaban mayor éxito estético no quita nada a la semejanza fundamental entre el Quijote apócrifo y este tipo de imitación.

Vemos, pues, que también en el proceso imitativo el Quijote apócrifo manifiesta esa única característica que tiene en común con el Quijote: la singularidad. La continuación de Avellaneda no se asemeja a ninguna otra, puesto que combina elementos y motivos de los tres tipos comunes de imitación. Indudablemente intenta continuar las aventuras y sacar partido de la popularidad de don Quijote, y, lo mismo que el Guzmán de Alfarache de Juan Martí, no tiene éxito. De este modo ratifica la opinión corriente de que - dejando a un lado el género y el estilo - lo que debe decidir más que nada la suerte de toda creación artística es la opinión pública. Al mismo tiempo, Avellaneda intentaba, conscientemente, reformar el Quijote, acercarlo más, como ya vimos, a las tendencias básicas del pensamiento contrarreformista, insistir en el aspecto instructivo, convertir, si podía, las aventuras de don Quijote en "trabajos". Esto corresponde, desde luego, a los esfuerzos postridentinos por extraer de las profanas obras pastorales y líricas el veneno 
mundano, poniéndolas a lo divino. Por último, y esto es quizás lo más importante, la creación de un Quijote apócrifo fue, al parecer, el único camino abierto a la pluma de Avellaneda. Por lo visto compartió en alto grado la tendencia barroca de apoyarse en formas y modelos literarios anteriores, a la vez que la atrofia barroca de la facultad creadora. Como veremos, halló en las aventuras quijotescas una serie de elementos que le servirían de base para su propio sistema de narrar. De esta mezcla de tradiciones iba a resultar un libro que constituiría una escuela propia, que sería una anormalidad literaria única en su género, aunque provista de ciertas características que eran indicio de la evolución de la novela europea.

\section{LA RELACIÓN ENTRE LOS DOS TEXTOS}

Antes de proceder a un análisis de los nuevos elementos que se añadieron a la creación cervantina y de la nueva personalidad y valores extraños que habían de desplazar del cuerpo de la obra el espíritu de su autor, debemos detenernos a analizar los incidentes particulares y los recursos estilísticos que pasaron, sin alterarse, de una versión a la otra. Este examen de coincidencias, de situaciones copiadas directamente, ha de servirnos ante todo para confirmar e ilustrar la relación entre Avellaneda y el Quijote original, de acuerdo con las ideas que se han expresado en el presente capítulo. Debemos mostrar no sólo qué rasgos llamaron la atención de Avellaneda, sino también por qué le atrajeron.

Hay ejemplos de paralelismo desde el comienzo de la versión apócrifa. La primera frase del primer capítulo recuerda a Cervantes: 
El sabio Alisolán, historiador no menos moderno que verdadero, dize que, siendo expelidos los moros agarenos de Aragón, de cuya nación él descendía, entre ciertos anales de historias halló escrita en arábigo la tercera salida que hizo del lugar del Argamesilla el invicto hidalgo don Quixote de la Mancha... ${ }^{12}$

Estas palabras han dado rienda suelta a la especulación erudita; se ha pensado que quizás contengan una clave criptográfica de la identidad del autor. Aunque no es imposible que haya en ellas tal revelación, esto al menos es innegable: "el sabio Alisolán” es reencarnación de Cide Hamete Benengeli. Tienen exactamente el mismo papel; ambos nos ofrecen manuscritos en árabe, con lo cual se quiere dar un aspecto de historicidad a la ficción. Cervantes se sirvió de este procedimiento para ridiculizar a los pretendidos historiadores de los libros de caballerías y quizás también como símbolo irónico de su propio despego. De este modo, Cide Hamete representa el plano de la historia, que de cuando en cuando se contrapone al sentido artístico de Cervantes, a la selección de detalles y disposición de los hechos. El autor arábigo dio ocasión a cierto tratamiento literario, fue una manera de resolver problemas de composición. Después de su primera aparición en el capítulo IX se presenta con regularidad a través del resto de la obra. Avellaneda, en cambio, menciona a Alisolán en la primera frase y apenas si vuelve a acordarse de él. Copia la estratagema irónica de Cervantes a fin de dar a su novela, desde un principio, el carácter de pseudohistoria. Luego, como la obra conserva todo el tiempo este carácter, como nunca se discute el valor artístico de los "hechos", Alisolán no hace ya falta.

12 Quijote apócrifo, pág. 8. 
Así, Avellaneda toma de Cervantes un rasgo que le puede servir para confirmar su propia definición del género novela. Empieza Avellaneda su cuarto capítulo con la frase:

Tres horas antes que el rojo Apolo esparziese sus rayos sobre la tierra, salieron de su lugar el buen hidalgo don Quixote y Sancho Pança... ${ }^{13}$

$\mathrm{Al}$ parecer, esto lo escribió Avellaneda teniendo presentes las famosas palabras de don Quijote: "Apenas había el rubicundo Apolo tendido por la faz de la ancha y espaciosa tierra..." Pero si Cervantes puso irónicamente estas palabras en boca de su héroe como parodia de la balumba estilística de las novelas caballerescas, Avellaneda las usa con toda seriedad, para comenzar un capítulo con frase elegante. Nos recuerda a ciertos críticos modernos que han elogiado este párrafo como ejemplo de las alturas a que podía llegar Cervantes. Avellaneda imita la frase más artificial y puramente decorativa de todo el Quijote - frase que Cervantes incluyó por lo que tiene de absurdo - , pero sin presentarla como imitación directa. "El rubicundo Apolo" se reduce a "el rojo Apolo", y la metáfora, artificial también y extravagante, pierde todo posible valor poético y se hace enteramente prosaica. Ni siquiera sirve ya para la ironía. Este proceso de selección y reducción, confirmado por otros ejemplos ${ }^{14}$, ilus-

\section{Quijote apócrifo, pág. 31.}

14 Un ejemplo apropiado es la siguiente estilización de una mujer, de acuerdo con el esquema petrarquista: “...fuera de las virtudes del ánimo, es sin duda blanca como el sol, las mexillas de rosas recién cortadas, los dientes de marfil, los labios de coral, el cuello de alabastro, las manos de leche, y finalmente, tiene todas las gracias perfectísimas de que puede juzgar la vista; si bien es verdad que es algo pequeño el cuerpo" (Quijote apócrifo, pág. 14). El "sin duda" y la alusión a la pequeñez reducen la entretenida elegancia 
tra el vigor de la orientación contrarreformista de Avellaneda, la seguridad de su instinto ascético. Así como los pensadores ascéticos reducían los objetos deseables del mundo al artificio de las joyas, sedas, metales preciosos, etc., cuya vanidad podían demostrar triunfalmente, así Avellaneda, desgajando trozos de estilo artificioso del Quijote, se ve forzado a volverse contra ellos para restarles valor. Es una aplicación estilística de la técnica ascética. De este modo, aun en la selección de palabras, Avellaneda mezcla inconscientemente lo que concebía como entretenimiento con lo que creía instructivo. Era una mezcla que, tanto en el estilo como en la trama, dio lugar a la abrumadora prosificación del Quijote. Es importante hacer notar que el paso de "rubicundo" a "rojo" probablemente no es cambio intencional, sino la infusión de un nuevo sistema de valores estilísticos personales dentro de un esquema imitado.

El único incidente completo que Avellaneda toma de la Primera parte es la anécdota que cuenta Sancho del pastor que trataba de pasar sus cabras, una a una, por el Guadiana. Considerándolo, al parecer, ilustración atinada y divertida de la manera rústica de Sancho, Avellaneda lo pasó, casi al pie de la letra, del capítulo XX del original a su propio capítulo XXI. Hay, sin embargo, una pequeña diferencia: en la versión de Avellaneda lo que impide que se complete la historia son circunstancias físicas y exteriores; Sancho insiste en que sus oyentes esperen hasta que todo el rebaño haya pasado a la otra orilla; sólo entonces continuará la narración. De hecho, parece

de la descripción, no a una relatividad irónica, sino a prosa. Avellaneda es incapaz, por temperamento, tanto de desentenderse de esas metáforas (se le había educado a ver el mundo a través de ellas), como de dejarlas inalteradas. Acepta los resultados del dualismo, pero no puede tolerar que Góngora, Quevedo o aun Cervantes se sirvan de ellas artísticamente; se vuelve contra ellas, tal como se le ha inculcado. 
exigir que el tiempo y la presentación del cuento correspondan a las circunstancias del acontecimiento contado; insiste, como el mismo Avellaneda, en la historicidad física. En el original, en cambio, la interrupción surge de una interacción psicológica entre el escudero y su amo; Sancho se niega a continuar cuando ve que don Quijote no recuerda el número exacto de cabras que han pasado el río. En un caso, ardid astutamente preparado; en el otro, absurda obstinación de campesino. Sin embargo, muletillas como "érase que se era” y “yendo días y viniendo días" son comunes a ambos. Avellaneda copió del Quijote un trozo que correspondía a su propia idea de la comedia, y luego lo exageró y amplificó, pensando producir de este modo un aumento correspondiente de regocijo. No se trataba aquí de selección y reducción, sino de selección y amplificación. Se hace que Sancho resalte ante su culto público como un rústico cómico y grotesco. Pero a pesar de este evidente paralelismo, a pesar de hallar en este suceso el material a propósito para una historia cómica, Avellaneda no puede imitar a Cervantes plenamente; desplaza la identificación personal de Cervantes con su creación.

Un último caso típico de imitación es la adopción de la fórmula de equivocación venta-castillo, tan fundamental en la Primera parte del Quijote. A Avellaneda parecen haberle impresionado particularmente las circunstancias picarescas de la estancia de don Quijote en la venta de Juan Palomeque el Zurdo. Así que hace que su héroe pase la noche en una venta semejante, cuando va de camino a las justas de Zaragoza. Pero Avellaneda no trata de continuar la ironía del delicado relativismo de Cervantes, su contrapunto de venta-castillo, pícarocaballero, etc. Para él la entrada del verdadero don Quijote en la posada y su encuentro con los huéspedes representan la 
introducción de un ambiente picaresco en lugar del paisaje pastoril de las aventuras anteriores. Ahora bien, este cambio de circunstancia le gustaba precisamente porque subrayaba la extraña locura del caballero, porque la mostraba en máximo contraste y conflicto con su mundo. Además, era tradicional que lo física y moralmente repugnante de este mundo picaresco diera lugar a una combinación de comedia y "trabajos", elementos básicos de la concepción de Avellaneda ${ }^{15}$. La consecuencia inmediata de este cambio de intención fue la prosificación de lo que en Cervantes era animado choque entre los esquemas literarios caballeresco y picaresco ${ }^{16}$. Hasta Maritornes, al pasar por la metamorfosis de Avellaneda, acaba en una descolorida "puta gallega”. Desaparece también la armonía de la construcción cervantina, por ejemplo, el contrario efecto que el bálsamo de

15 Hemos visto cómo en el Guzmán de Alfarache la novela picaresca postridentina sigue la polémica ascética en contra del "mundo". El pícaro vive en un mundo desprovisto de significación personal y está en él para engañar a los demás y para llegar él mismo al desengaño definitivo. Avellaneda aprovecha aquí el momento en que Cervantes se acerca más a este mundo negativo.

16 No sólo de Cervantes heredó Avellaneda la tradición picaresca, sino también de Quevedo y de la Celestina. Hay una serie de alusiones al Buscón, que entonces no estaba aún impreso pero del cual debió conocer un manuscrito. Las experiencias que tiene Sancho en la cárcel de Alcalá son quevedescas en el estilo y en los detalles. Hasta hay una imitación directa de la famosa escena de los gargajos. (De uno de ellos se dice que es "verdinegro", adjetivo usado sólo en la versión manuscrita. Véase la edición de Américo Castro en Clásicos Castellanos.) Por otro lado, Bárbara "la mondonguera" es, para usar la frase de Avellaneda, "hija de la Celestina"; Bárbara tiene la cicatriz de la Celestina, y Avellaneda llega hasta a comparar los talentos profesionales de las dos. Siempre que Avellaneda hallaba material que pudiese contribuir al prosaísmo de su historia cómica y aumentase los "trabajos" de su "mundo", no vacilaba en adoptarlo. Hay en el Quijote apócrifo elementos de otras continuaciones apócrifas que nunca vieron la luz. 
Fierabrás produce en don Quijote y en Sancho. Lo único que le interesa a Avellaneda es llevar al colmo el aislamiento vesánico de don Quijote, a fin de que su ejemplo tenga el máximo efecto moral y cómico. La venta de Juan de Palomeque el Zurdo puede compararse a un puente por el cual Avellaneda creía llegar al Quijote, un ilusorio lugar de encuentro para dos concepciones que no podían encontrarse jamás. Avellaneda podía argüir que había pasado el puente y que estaba perfeccionando la enseñanza cervantina, pero esto mismo no era verdad. El imitador halló en la venta un recurso práctico para escribir, pero el Quijote se le fue de las manos en el momento en que quiso introducir en él su visión postascética, su "mundo" de valores y creencias ${ }^{17}$.

Así, el Quijote es para Avellaneda una historia cómica hecha para entretener e instruir. Como veremos, Avellaneda in-

17 El siguiente pasaje, copiado casi literalmente de Cervantes, nos muestra lo limitada que era la visión que Avellaneda tenía del Quijote, y también el motivo que le llevó a imitar las aventuras de la venta:

\section{Avellaneda}

Cervantes

[El ventero dice:]

Señor caballero, aquí no habemos Sólo he menester que vuestra mermenester cosa alguna, salvo que ced me pague el gasto que esta novuesa merced o este labrador que che ha hecho en la venta, así de la consigo trae me paguen la cena, paja y cebada de sus dos bestias como cama, paja y cebada, y váyanse tras de la cena y camas (I, XVII). esto muy en hora buena (págs. 4l42).

De este modo, Avellaneda aprovecha un pasaje en que la vida impone sus exigencias prosaicas al individuo, en que el mundo se separa de don Quijote y lo domina. Algunas veces este prosaísmo degenera en pura vulgaridad, y, al copiar del original, Avellaneda insiste en estos aspectos mucho más que Cervantes. La prueba de historicidad es la presentación de los hechos, preferentemente de los sórdidos y repugnantes: 
terpreta estas palabras ingenuamente, al pie de la letra: historia equivale a sucesión de hechos; comedia, a una yuxtaposición y contraste extravagante de hechos; instrucción, a una intercalación de sentencias morales; y entretenimiento, a un arreglo elaborado de los elementos de la comedia. Una vez establecidos estos conceptos, escoge ciertas partes del original para centrarse en ellos, y construye nuevos incidentes sobre los cimientos de los antiguos. Consideraremos también la manera o motivo de imitar. Como hemos visto, Avellaneda parece participar en las tres tradiciones imitativas de su época. Al mismo tiempo trata de mantener la esencia del original, de reformarlo y de usar sus recursos narrativos para poner de relieve la estructura de su propia personalidad y sus valores. Cada uno de estos contradictorios motivos parece estar presente siempre y limitar el libre desarrollo de cualquiera de las tendencias. Se puede determinar el estado de la narración y del estilo de cualquier pasaje, viendo cuál de las tendencias predomina. El grado de aproximación al original, la mayor o menor intensidad del esfuerzo por sacar conclusiones morales y la cantidad de elementos peculiares de Avellaneda dan forma a cada incidente y a la novela en conjunto, produciendo, al combinarse, una infinita variedad de matices. No basta comprender sólo uno de estos factores, ni apoyarse únicamente en una fracción de ellos, para dar al Quijote apócrifo explicación adecuada.

Como la camisa era un poco corta por delante no dejaba de descubrir alguna fealdad... baxóse un poco y descubrió de la trasera lo que de la delantera había descubierto y algo más asqueroso (pág. 75).

Estaba en una camisa, la cual no era tan cumplida, que por delante le acabase de cubrir los muslos, y por detrás tenía seis dedos menos; las piernas eran muy largas y flacas, llenas de vello y no nada limpias... (I, XXXV). 
Aunque en el capítulo siguiente nos ocuparemos más del tercer tipo de imitación, de los valores, sentimientos y puntos de vista que Avellaneda introduce en el Quijote, de lo nuevo más que de lo viejo, hay que tener presentes todos los factores mencionados si no se quiere falsear y desfigurar el texto. Además, no hay que olvidar la posible relación que existe entre las dos Segundas partes. Hay en el Quijote apócrifo una serie de incidentes y de frases que hacen pensar que Avellaneda conocía el trabajo que estaba haciendo Cervantes, o viceversa, y los recordaremos de cuando en cuando para ilustrar ideas e interpretaciones. Sin embargo, puesto que en ningún caso son tan precisos como en las imitaciones de la Primera parte, y puesto que su explicación es más dudosa y requiere un análisis más detallado, se hablará de ellos en el apéndice.

Hasta aquí nos hemos ocupado en determinar las circunstancias históricas y estéticas; hemos reunido los instrumentos y abierto el camino. Ahora podemos acercarnos al objeto de nuestra investigación, al Quijote apócrifo, cuyo estudio ha de confirmar o invalidar los esfuerzos realizados. 


\section{IV \\ EL QUIJOTE APÓCRIFO}

\section{El legado de Cervantes}

El rasgo quizás más característico del gran género inventado por el mundo moderno, la novela, es que refleja, no ya el mito (el hombre en relación con su trascendencia), no ya la sociedad (el hombre en relación con su clase), ni los sentimientos u opiniones (el hombre en relación con su inmanencia), sino un mundo complejo que abarca todos estos niveles. Si la novela, como ya Cervantes había dicho con tanto acierto, combinaba y fundía todos los géneros anteriores: la épica, la lírica, la tragedia y la comedia, también combinaba la particular visión del mundo de cada uno de ellos. Hay que añadir que esta verdad elemental nada tiene que ver con la perfección de la creación novelística; es un requisito del género, y como tal está íntimamente ligado a las características formales y particularmente al hecho de que se trata de una narración en prosa. Se podría objetar que todo arte, siendo imitación de la vida, presupone un mundo hipotético, pero lo que importa aquí es que el novelista convierte este requisito de la narración en finalidad, en propósito de su creación. El mundo, definido así, no es trasfondo ni escenario forzoso en que ha de efectuarse un acontecimiento o una expresión de sentimientos, sino que es el objeto estético mismo. 
Si estamos de acuerdo con este criterio, ¿en qué medida es novela el Quijote apócrifo? ¿En qué medida reconoce Avellaneda este nuevo género? La respuesta va inevitablemente ligada a la importancia que pueda tener cada uno de los tres tipos de técnica imitativa antes analizados con respecto a los otros dos. Es decir, el interés que Avellaneda tenía en valerse del éxito del Quijote original, en utilizar la irónica visión del mundo de Cervantes con el fin de hacer comedia, destruyó la novela; y también la destruyó su esfuerzo por reformar el modelo, por combinar el problema cervantino con la enseñanza ascética. Estas dos primeras tradiciones de la imitación traían consigo elementos que tendían a relegar a segundo plano el mundo creado, elementos didácticos o cómicos, y por lo mismo extra-novelísticos. Por otro lado, en la medida en que Avellaneda se sirvió de la tercera técnica imitativa, infundiendo en el esquema del libro y de la trama la estructura característica de su propia personalidad y de sus valores, en la medida en que revaloró a don Quijote y a su mundo, se aproximó a la creación de una nueva novela. Las caricaturas y las moralejas son de suyo extranovelísticas, pero la recreación y la reinterpretación podrán también revelarnos, si no ya el nombre de Avellaneda, al hombre mismo; no al perverso imitador, sino al novelista frustrado.

Para penetrar en este mundo apócrifo, para comenzar a juzgar sus valores y a hacer un esquema de su anatomía, lo más conveniente será partir de la adaptación que hizo Avellaneda del movimiento narrativo original. Ya hemos insinuado antes que la infusión de la nueva esencia en el novelar de segunda mano estaba estrechamente relacionada con la probable esterilidad de Avellaneda. El Quijote, decíamos, fue para Avellaneda un medio conveniente de expresar una serie de valores que en sí mismos no estimulaban, sino atrofiaban la creación. Fue un 
instrumento adecuado para encarnar su visión del mundo en un relato. El destino que alcanzó en manos de Avellaneda el esquema básico de la creación cervantina, la trama quijotesca, debería permitirnos volver a nuestra hipótesis preliminar acerca de los valores de Avellaneda, para precisarla más. La característica curva de acción de don Quijote habrá de servirnos de punto de partida en la búsqueda del verdadero Avellaneda.

El primer ejemplo definitivo de la nueva trama quijotesca lo hallamos en el capítulo III. Don Quijote ha dado el paso decisivo de ponerse la armadura que le ha encomendado don Álvaro Tarfe. Sancho está junto a él y don Quijote le dice:

- ¿Qué te parece, Sancho? ¿Estánme bien? ¿No te admiras de mi gallardía y brava postura?

Esto dezía paseándose por el aposento haziendo piernas y continentes, pisando de carcaño, y levantando más la voz, y haziéndola más gruesa, grave y reposada; tras lo cual le vino luego súbitamente un accidente tal en la fantasía, que, metiendo con mucha presteza mano a la espada, se fue acercando con notable cólera a Sancho, diziendo:

-Espera, dragón maldito, sierpe de Libia, basilisco infernal: verás por experiencia el valor de Don Quijote, segundo San Jorge en fortaleça...

Sancho, que le vio venir para sí tan desaforado, començó a correr por el aposento, y metiéndose detrás de la cama, andaba al derredor della huyendo de la furia de su amo... Andaba en esto tras del pobre Sancho al derredor de la cama, diziéndole mil palabras injuriosas, $\mathrm{y}$, juntamente con cada una, arrojándole una estocada o cuchillada larga; que si la cama no fuera tan ancha como era, lo pasara el pobre Sancho harto mal... ${ }^{1}$

1 Quijote apócrifo, pág. 29. 
Don Quijote sólo cede ante las súplicas de Sancho cuando éste le promete entregar todas sus damas encantadas y sus tesoros escondidos. Entonces don Quijote puede volver a su estado normal y explicar su locura:

¿No ves, Sancho, que era fingido, no más de por darte a entender mi grande esfuerço en el combatir, destreza en el derribar, y maña en el acometer? ${ }^{2}$

En seguida, y después de un cambio de asuntos algo desconcertante, don Quijote invita a Sancho a comer con él para planear juntos una nueva salida.

Por supuesto, salta a la vista que esto no es obra de Cervantes. Con su "accidente en la fantasía", el don Quijote de Avellaneda no necesita preparar ni presentar cuidadosamente sus alucinaciones, no necesita engaño de los sentidos, ni nubes de polvo, ni agitados brazos de molino, ni ruidos sospechosos en la noche. No hace falta que una manifestación del "parecer" venga a tranquilizar la razón de don Quijote o a fortalecerlo en su engaño. El "fingir" de don Quijote es capaz de abarcarlo todo. El movimiento narrativo, es decir, la acción de la trama, liberada ya de estas necesidades, comienza súbitamente, se eleva a un estado de tensión imposible, y termina de improviso, con un cambio artificial de conversación. En efecto, parece a primera vista que don Quijote se ha vuelto enteramente loco; si antes su entendimiento era limitado y humilde, ahora se ha descarriado por completo. Por eso, el movimiento no puede reducirse ya al suave subir y bajar de sucesos y conversaciones afines, como lo vemos en Cervantes; falta ya la cordura que pone coto a las indiscreciones de la voluntad. El don Quijote

2 Ibid., pág. 30. 
original jamás podía haber tomado a Sancho por un dragón; es muy raro que sea dos veces víctima de la misma alucinación. El "loco-cuerdo" posee en el fondo una cordura y una memoria primarias que van regulando las acciones a medida que surgen de su voluntad. En la versión de Avellaneda, en cambio, como el movimiento narrativo carece de esa ancla, es inseguro y arbitrario; es solamente expresión de una lógica trastornada y va avanzando a saltos que producen, cada uno, un máximo de tensión y de divergencia de la realidad. Como sucede a veces con los locos de verdad, una existencia que se desarrolla en forma de crisis sucesivas se vuelve patológica.

Avellaneda sabía perfectamente que tendría que inventar un contrapeso a esta irregularidad si quería evitar que de pronto se viniera abajo la narración. Al final de la primera salida, también el don Quijote de Cervantes parece volverse enteramente loco; se cree Valdovinos y Abindarráez, como el héroe, Bartolo, del Entremés de los Romances, obra que Cervantes usó como fuente de este episodio ${ }^{3}$. Pero eso podía ocurrir únicamente al regresar don Quijote a su casa, puesto que un alejamiento tan absoluto de la realidad tiene que dar como resultado la interrupción del movimiento hacia adelante; sólo puede llevar al caos y a la muerte, a la afrenta o al encerramiento del loco. El don Quijote apócrifo bordea continuamente estas posibilidades, y uno de los grandes problemas narrativos es evitar su realización. De don Quijote puede brotar una acción (de ahí que sea útil a Avellaneda), pero nunca una acción continua. En la aventura de la venta, que, como ya vimos, es imitación de la de Cervantes, hay una crisis menor cuando don Quijote, diciéndose rodeado de enemigos, se niega a quitarse el morrión:

3 Véase para esto el ya citado estudio de MenÉndez Pidal, Un aspecto en la elaboración del "Quijote". 
Llegó en esto Sancho, y pudo acabar con él a puros ruegos se quitase el morrión ${ }^{4}$.

A la mañana siguiente, el ventero, queriendo vengarse del golpe que le ha dado don Quijote, está a punto de dispararle su escopeta, y a no ser por una oportuna disuasión, aquí acabaría la historia. Mosén Valentín - el bondadoso cura - y don Álvaro Tarfe, que hace de protector, rescatan a don Quijote en repetidas ocasiones, a lo largo de toda la obra. Al presentar el sueño épico de Alonso Quijano como vanidad completa y locura patológica, Avellaneda tropieza con las limitaciones mismas de la presentación. El movimiento que resulta de esta interpretación es un sucesivo apartamiento perpendicular del mundo, y sólo “a puros ruegos" de parte de los otros personajes vuelve a encarrilarse en la horizontal.

Muy a menudo, ante el dilema de los efectos destructores de cada incidente y la necesidad de presentarlos, Avellaneda encuentra una segunda solución. Con gran precaución ordena los sucesos de modo que resulten ventajosos para don Quijote. Así, Avellaneda oscila entre la brutalidad humillante y las circunstancias fortuitas, y jamás llega a concebir esa armonía íntima de oposición y colaboración que Cervantes pudo crear con su ironía tierna, su apartamiento de "padrastro". En la venta, por ejemplo, Avellaneda hace que don Quijote duerma en una "razonable cama”, en lugar de aquel otro sustituto detestable, digno del ambiente picaresco; y así también hace que a la mañana siguiente don Quijote pague al ventero sin dificultad. Esta misma tendencia se hace aun más evidente al comienzo del capítulo que sigue:

4 Quijote apócrifo, pág. 38. 
Caminaron la vía de Çaragoça el buen hidalgo don Quixote y Sancho Pança, su escudero, y anduvieron seis días sin que les sucediese en ellos cosa de notable consideración...5

Tanto Avellaneda como sus protagonistas deben descansar después del exceso de tensión a que habían llegado los acontecimientos en la venta. Con persuasiones sensatas, y evitando desenlaces, es como Avellaneda va engarzando su narración a través de un mundo estático y formal, un mundo incapaz de colaborar en lo más mínimo con la locura de don Quijote.

Los cambios fundamentales realizados en el impulso al movimiento narrativo sugieren el motivo por el cual Avellaneda tuvo necesidad de don Quijote. Ambas cosas pueden tener relación con esa crisis de valores e ideas que, como ya hemos dicho, fue resultado de la Contrarreforma. En otras palabras, lo que sucede al don Quijote de la versión apócrifa corresponde íntimamente a lo que ocurrió al nuevo autor y a sus lectores. El hecho de que don Quijote se haya vuelto enteramente loco y que su movimiento derive siempre hacia la perpendicular puede quizás relacionarse con la división postridentina entre el individuo y su mundo. El contraste que se ha señalado entre la personalidad creadora de Avellaneda y la de Cervantes, y que proviene originariamente de su respectiva actitud ante la Contrarreforma, parece confirmado por el esquema de movimiento que siguen sus héroes. Un don Quijote, aislado en su locura, subraya la irrevocable separación entre el hombre como individuo y el mundo, lo vano de toda acción individual; el otro don Quijote, ansioso de amistad y de simpatía humana, forja con su voluntad y con su razón designios de armonía, de agridulce reconciliación con la residencia en la tierra. El nuevo don Qui-

5 Ibid., pág. 45. 
jote vive, como veremos, a diferencia del antiguo, dentro de una soledad comparable, por lo menos en su origen, a la de los grandes estilistas barrocos.

Sería erróneo, sin embargo, volver a identificar ahora a Avellaneda con el ascetismo. Un don Quijote ascético, como ya observábamos, habría sido profundamente consciente del carácter ajeno del mundo exterior, y no patológicamente inconsciente de él. Su aislamiento no provendría sólo de su propia locura, sino también de la perversidad del mundo. Zárate, llevado de su afán casi épico de destruir el mundo, expresó con el vigor nada escolástico de sus metáforas toda la fuerza de su resentimiento. Escribió la historia de su propio conflicto con la existencia, y, por lo tanto, no necesitó de esquemas preconcebidos de creación. En otras palabras, el mensaje de Zárate, su ser y los valores que regían su vida originaron, ellos mismos, una forma y un estilo propios; en Avellaneda, en cambio, no ocurrió tal cosa. ¿A qué se debe esto? En el caso de Zárate, la respuesta es evidente: era polemista y subrayaba la escisión entre el individuo como tal y el mundo; por consiguiente, veía el mundo como problema, como el enemigo con el cual había que luchar. En cambio - y ésta era la base de nuestra hipótesis preliminar- Avellaneda parece creer en un mundo reconstruido formalmente, un mundo ya sin veneno e inofensivo para el hombre. De esto deduce que sólo un lunático como don Quijote trataría de expresar otro punto de vista. Avellaneda no concibe el mundo ni como enemigo ni como problema, sino como benéfico convenio divino y humano del cual él forma parte. Y por formar parte, no podía revelar los contornos de lo cuerdo y de lo justo de su mundo; no era capaz de recrearlo en una acción novelística. Eso sólo lo podía hacer el loco y descarriado antihéroe que tuvo que tomar de Cervantes. 
He aquí la extraña paradoja del "arte" de Avellaneda. Por una parte quiere escribir una novela, es decir, presentar un "mundo", y por otra encuentra que no puede hacerlo sin apelar a una forma de creación que implica una visión radicalmente distinta de la suya. Más aún, el indispensable movimiento narrativo (para delinear los contornos de un mundo no basta la descripción inmóvil) tiene que depender de un personaje que le parece irremediablemente loco y profundamente antipático. Ya hemos insinuado la causa: por más que Avellaneda quiera novelar, su "mundo" no es "novelable" en sí. Sólo puede llegar a la novela por medio de un héroe de "opuesto humor" al suyo, un don Quijote que pueda moverse en esta clase de "mundo" precisamente porque para Avellaneda es antiheroico. Visto así, el Quijote apócrifo es más que un simple producto de "tosquedad" o de "insensibilidad", como quería hacernos creer la crítica de hace unos años. La intención de Avellaneda puede haber sido más profunda de lo que él suponía; ciertamente era algo más que el mero propósito de sacar provecho de una imitación extravagante, o que el piadoso deseo de reformar los elementos sospechosos del original. Se trata, por lo menos en parte, de un préstamo genérico, un préstamo de movimiento narrativo capaz de comunicar una visión y una estimación del mundo. Se trata de un hombre que, sin medios vitales para ello, quiere escribir una novela.

Ahora bien, estas consideraciones basadas en el género literario no nos ofrecen más que un punto de partida para la interpretación de libro. Pero es un punto de partida muy sugestivo; evoca una serie de problemas y preguntas particulares que pueden servirnos de guía. ¿Cómo se puede definir la nueva locura de don Quijote? ¿Cómo se relaciona el Sancho apócrifo con esta locura? ¿Qué tipo de mundo no se presta a 
la novela? ¿Cuáles serán los valores que determinan esa clase de mundo? ¿Cómo se refleja en el estilo la nueva escisión entre don Quijote y su circunstancia? ¿Cuáles son las relaciones entre este estilo y el de los escritores barrocos que entienden la misma escisión de un modo muy distinto? Así podemos dar comienzo a la exploración seria del Quijote apócrifo con cierta orientación preliminar. Sabemos provisionalmente lo que vamos buscando.

\section{EL "LOCO ESCOLÁSTICO"}

La locura del don Quijote cervantino - Unamuno fue de los primeros en observarlo - surgió de la aberración, no de su inteligencia, sino de su voluntad. En cambio, como acabamos de decir, la locura del héroe de Avellaneda no pasó de los límites de la inteligencia. Fuera de los efectos extraños que ello tuvo en el curso de la narración, ¿qué significa este contraste? ¿Se trata únicamente de la diferencia entre el personaje y la caricatura? ¿O hay una genuina distinción psicológica entre los dos caballeros, que nos confirmará la integridad de la imitación de Avellaneda? Para responder a esto, examinemos los dos don Quijotes, ya no de acuerdo con complejos y neurosis, sino basándonos en la psicología de su tiempo. Los varios esfuerzos que se han hecho para aplicar los descubrimientos de Freud a la creación cervantina han dado lugar a inconvenientes anacronismos. Al menos por lo que respecta a la literatura, parece que la psicología es una ciencia, no absoluta, sino vital, válida ante todo para la generación de hombres que la inventó y que se retratan a sí mismos a su luz, artísticamente o no. Tomemos como guía de esta interpretación psicológica el Tratado del alma, de Luis Vives. 
Vives explica la división aristotélica de la psique humana en las facultades de memoria, entendimiento y voluntad del modo siguiente:

Creado el hombre para la felicidad eterna, se le ha concedido la facultad de aspirar al bien, para que desee unirse a él. Esta facultad se llama voluntad. Y como no se puede desear lo que no se conoce, existe a este fin otra facultad, que se llama inteligencia. Además, nuestro espíritu no permanece siempre en un mismo pensamiento, sino que pasa de unos a otros, por lo cual necesita un cierto depósito en que, al presentarse los nuevos, conserve los anteriores como tesoro de cosas ahora ausentes, las cuales reproduzca y tome cuando es menester. El nombre de esta función es la memoria ${ }^{6}$.

Con ese "aspirar al bien", que es la función de la voluntad, queda definido el amor: "El amor no es otra cosa que... la inclinación o movimiento de la voluntad hacia el bien". Es ante todo un proceso libre, pues la voluntad, si bien no puede expresarse salvo a través del amor, posee cierta libertad de elección y cierta capacidad de determinar el objeto de su inclinación. En ella reside el destino que los hombres se fijan a sí mismos. Según Vives, la voluntad puede determinar la presentación racional de los hechos:

...dentro de la deliberación misma, puede mandar que se aplace el asunto o que se suspenda totalmente y se dirija el pensamiento hacia otro objeto, del mismo modo que un príncipe puede ordenar a su consejo delibere respecto de un asunto cualquiera o que se suspenda y aun quede suprimida toda deliberación... En efecto, siendo tantos los objetos que se presentan a nosotros

6 Luis Vives, Tratado del alma, La Lectura, Madrid, s.f., pág. 67. 
para elegir, aun cuando la razón demuestre con poderosos motivos que uno de aquéllos es el bueno y aconseje adoptarle, si se ofrece otro que tenga algún aspecto del bien, aun sumamente tenue, puede la voluntad inclinarse a él y abrazarle con esa sola pequeñísima sospecha, mientras rechaza al otro que posee una muy excelente forma y substancia del bien ${ }^{7}$.

Así que la función de la voluntad es amor, aspiración al bien, mientras que la función del entendimiento es determinar lo bueno, y justificarlo bajo el mando de la voluntad. Al mismo tiempo, la memoria da a esas facultades una continuidad esencial de método y propósito. Si a alguna de ellas se le da más importancia que a las demás, el resultado es catastrófico. El hombre de memoria es una rareza; al hombre de entendimiento lo paraliza la relatividad de lo bueno; y el hombre de voluntad puede convertirse en un don Quijote.

Al principio de la Segunda parte, don Quijote declara su voluntad de ser caballero andante, su conciencia de que el bien - esto es, su propio camino al cielo - está sólo en ese destino. "Caballero andante he de morir... que otra vez digo que Dios me entiende". Es una declaración definitiva. Como hombre de voluntad, don Quijote era también hombre de amor. Si a Dulcinea, por ejemplo, el entendimiento la juzgaba campesina, según lo dicho por Vives, la voluntad quedaba en libertad de rechazar este juicio a favor de otro basado sólo en una posibilidad muy remota ${ }^{8}$. Los granos de trigo que se deslizaban por sus dedos, si la voluntad lo exigía, se volvían perlas. El hombre de

7 Ibid., págs. 128-129.

8 Cuando se trata de decidirse por el bien, Vives concede a la voluntad el derecho de desentenderse de la evidencia que aduce el entendimiento. Don Quijote se sirve de esta libertad, no sólo para decidirse, sino también para sostener y defender su decisión. 
voluntad no concibe el mundo como problema extraño, sino como respuesta a su deseo, y el entendimiento ha de ser realmente "ingenioso" si se quiere mantener el engaño. No por simple casualidad el mundo del Quijote fue pastoril; en cierto modo la transformación de Aldonza Lorenzo en Dulcinea corresponde a la metamorfosis de una dama de la corte en Filis o Filomena. Don Quijote persiguió su destino con los mismos medios que usó Garcilaso para cortar el mundo "a su medida".

Sin embargo, las otras dos facultades de don Quijote, el entendimiento y la memoria, no eran impotentes. Cada uno de sus fracasos se hacía consciente en el uno y se registraba en la otra. Si en la Primera parte don Quijote podía atribuir sus derrotas a la maldad de los encantadores, era, sin embargo, raro que se permitiera incurrir dos veces en el mismo error. Ya en el capítulo XXXIII admite de buen grado que su venta no es castillo. En la Segunda parte es aún más evidente la intransigencia de su entendimiento para con las exigencias de su voluntad, y la troje de desilusiones que tiene en su memoria va almacenando cosecha tras cosecha. Pero la memoria, si por un lado iba preparando el desengaño definitivo, por el otro daba continuidad a su amor. El amor de don Quijote fue, pues, un amor épico más que lírico, fue continuidad de memoria y voluntad cuya expresión era la búsqueda de Dulcinea, tema central de la Segunda parte. Don Quijote no había perdido su alma ni parte alguna de ella; era un hombre total, y como tal debía morir.

Ahora bien, al principio del Quijote apócrifo, el falso don Quijote recibe una carta de Dulcinea:

"Sobrescrito. A Martín Quijada el Mentecato". -El portador désta había de ser un hermano mío, para darle la respuesta en las costillas con un gentil garrote. ¿No sabe lo que le digo, señor Quijada? Que por el siglo de mi madre, que si otra vez me 
escribe de emperatriz o reina, poniéndome nombres burlescos, como es "A la Infanta manchega Dulcinea del Toboso" y otros semejantes que me suele escribir, que tengo de hazer que se le acuerde. Mi nombre propio es Aldonza Lorenço o Nogales, por mar y por tierra?

Es una carta digna del Avellaneda del prólogo y tiene consecuencias terribles: don Quijote renuncia a su amor por Dulcinea. Para dar expresión al nuevo ser creado por la renuncia, cambia su título de "Caballero de la triste figura" por el de "Caballero desamorado”. Hay aquí algo más que mera caricatura, puesto que la caricatura hubiera desfigurado y aumentado, a la par de todas las demás características externas del don Quijote original, el amor por Dulcinea. Es significativo que Cervantes mismo parece haber reconocido la gravedad y la importancia psicológica de este cambio. Don Quijote escucha en la venta una discusión sobre la versión apócrifa:

- Lo que a mí... más desplace es que pinta a don Quijote ya desenamorado de Dulcinea del Toboso.

Oyendo lo cual don Quijote, lleno de ira y de despecho, alzó la voz y dijo:

-Quienquiera que dijere que don Quijote de la Mancha ha olvidado, ni puede olvidar a Dulcinea del Toboso, yo le haré entender con armas iguales que va muy lejos de la verdad; porque la sin par Dulcinea del Toboso ni puede ser olvidada, ni en don Quijote puede caber el olvido... ${ }^{10}$

Es decir, Cervantes parece haberse dado cuenta de que, una vez desprovisto de amor, toda la estructura psicológica de su

9 Quijote apócrifo, pág. 21.

10 Quijote, II, LIX. 
héroe tiene que venirse abajo. Sabía que al desaparecer la aspiración de la voluntad debían quedar destruidas inevitablemente tanto la continuidad de la vocación como el apogeo del desengaño. La memoria y el entendimiento perderían el resorte que los mueve. En don Quijote no podía caber el olvido.

La frase "accidente en la fantasía", que Avellaneda usó para explicar el extravagante ataque contra Sancho, expresa muy bien esta nueva locura del entendimiento. Volviendo a Vives en busca de explicación, vemos que define la fantasía como la parte del entendimiento que representa en la pantalla de la mente las imágenes tomadas de la memoria; corresponde aproximadamente a lo que ahora llamamos imaginación. Pero, continúa Vives, cuando la razón o el juicio no cumplen con su deber, la fantasía sufre una extraña aceleración:

Mas como la fantasía se halla entonces emancipada de la censura de la razón, saca cosas de la memoria sin medida ni orden, por lo cual vemos en sueños tantos absurdos, necedades e incoherencias, como sucede en una enfermedad que ataque a la cabeza $^{11}$.

Vives explica este proceso con mayor detenimiento en el capítulo sobre "La razón":

La razón pasa volando por esas imágenes, o tan levemente como si no las recibiese. Consiste esto en que nada toma de los particulares accidentes; más bien mira a lo lejos y se aparta cuanto puede de lo que ha visto; pues si se mezclase y envolviese en ello, se vería arrebatada cual por un torrente, según sucede en el estado de embriaguez y de furor... ${ }^{12}$

11 VIVES, op. cit., págs. 142-143.

$12 \mathrm{Ibid}$., págs. 85-86. 
El desarrollo de la locura consiste, según Vives, en un derrumbe dentro del entendimiento; ocurre cuando, después de algún accidente, la razón pierde su imperio sobre la fantasía, cuando la fantasía deja de ser sierva para convertirse en señora.

No hace falta recurrir a la frase "accidente en la fantasía" ni a la pérdida del amor para saber que este análisis de Vives es definición cabal de la locura del don Quijote de Avellaneda. El torrente de absurdo y locura de que habla Vives tiene su ilustración viva en los nuevos soliloquios del Caballero. Es su estilo personal y puede extenderse por páginas y páginas. Tomemos un pasaje al azar:

Ya veis, ínclitos Guzmanes, Quiñones, Lorençanas y los demás que me oís, cómo mi tío el rey don Alfonso el Casto, siendo yo hijo de su hermana, y tan nombrado cuanto temido por Bernardo, me tiene a mi padre el de Saldaña preso, sin querérmele dar; demás de lo cual, tiene prometido al emperador Carlo-Magno darle los reinos de Castilla y León después de sus días; agravio por lo cual no tengo de pasar de ninguna manera, pues no teniendo él otro heredero sino a mí... no tengo de permitir que estrangeros entren en posesión de cosa tan mía: por tanto, señores, partamos luego para Roncesvalles, y llevaremos en nuestra compañía al rey Marsilio de Aragón, con Bravonel de Çaragoça, que, ayudándonos Galalón con sus astucias y con el favor que nos promete, fácilmente mataremos a Roldán y todos los doze pares; y quedando en aquellos valles mal ferido Durandarte, se saldrá de la batalla; y por el rastro de la sangre que dexará, irá caminando Montesinos por una áspera montaña, aconteciéndole mil varios sucesos, hasta que, topando con él, le saque por sus manos, a instancia suya, el coraçón, y se le lleve a Belerma, la cual en vida fue la mira de sus cuidados... ${ }^{13}$

13 Quijote apócrifo, pág. 186. 
El rasgo característico de este estilo es la sucesión de imágenes, la carencia de una inteligente organización interna. Cada idea o imagen sugiere la siguiente en loca aceleración que sólo acaba cuando la memoria se agota o cuando el que habla se encarniza en furioso ataque contra la sombra más próxima. Dicho con las palabras de Vives, es el estilo de la fantasía emancipada.

Avellaneda define aún con mayor precisión el tipo de locura de don Quijote:

En amaneciendo Dios se despertó don Quixote; que el caos que tenía en su entendimiento, y confusión de especies de que traía embutida la imaginativa, le servían de tan desconcertado despertador, que apenas le dexaban dormir media hora seguida ${ }^{14}$.

Es decir, un accidente en la fantasía sume el entendimiento en el caos, destruye el sistema lógico de las especies. El estilo del monólogo citado carece de orden racional, de metáfora retórica, de comparaciones, de premisas y conclusiones. Avanza de acuerdo con su propia secuencia arbitraria, y es por tanto opuesto al silogismo. Representa lo antilógico de la locura más bien que lo ilógico del error. Al desaparecer del Quijote apócrifo el "Caballero de la triste figura", desapareció con él el "loco cuerdo". El nuevo don Quijote es el "loco escolástico" ya plenamente desequilibrado.

Como ya sugerimos antes, la transformación por la que Avellaneda hace pasar el alma de don Quijote puede compararse con la transformación que los autores ascéticos impusieron a la visión renacentista del mundo. Cuando desterraron el amor de la realidad externa, ésta se volvió arbitraria, confusa, estéril. Su orientación, su espacio y su tiempo perdieron toda

14 Ibid., pág. 190. 
congruencia y sólo pudieron quedar enlazados desde fuera y por medio de un insistir en la relación entre causa y efecto. Se requería un sistema de orden trascendental y escolástico que mantuviese unido el dislocador caos del mundo. Del mismo modo, cuando quitan a don Quijote el amor, cuando su desengaño pasa de la voluntad al entendimiento, su cerebro enfermo se niega a aceptar la lógica de causa y efecto, las geometrías que delimitan el espacio y el tiempo. Estas cosas, como hacíamos notar, tenían que imponerlas desde fuera, "a puros ruegos", los otros personajes. Pero para que don Quijote llegase a la antilógica de su nueva locura había que destruir la coherencia de su vocación caballeresca. El flujo vivo de voluntad y memoria que fundamentaba su propósito debía interrumpirse para dejar paso a las secuencias arbitrarias de una fantasía desbordada. Se reemplazó la voluntaria aspiración al bien por un cómico engaño de la mente; el nuevo don Quijote puede ser terco, pero nunca persigue un fin determinado. El símbolo de esta pérdida de constancia que sufre su visión es la pérdida del amor a Dulcinea.

Si admitimos, pues, que estos cambios son algo más que mera consecuencia de la caricatura, y que se ha dado nueva base psicológica a la locura de don Quijote, ¿qué importancia tiene esto para nuestra hipótesis sobre el autor? Avellaneda, como dijimos, al quitar a don Quijote el amor, está usando un método parecido al de la polémica ascética. Pero no aplica este método a toda una visión del mundo, sino al alma de un solo individuo. Al parecer, Avellaneda confía no sólo en las técnicas ascéticas de destrucción, sino también en la reconstrucción que estaban destinadas a preparar. El resultado inevitable es que para él cualquier amor, cualquier propósito voluntario, cualquier acción épica individual como la intenta- 
da por el héroe de Cervantes, sólo podía ser locura y disparate. La ilusión no cabía ya dentro de un mundo que, a los ojos de Avellaneda, se había liberado de su problematismo, y vino entonces a depositarse, subjetivamente, en el entendimiento de don Quijote. Ni el "baciyelmo" cervantino, ni la "figura" conceptista podían existir para Avellaneda. Como dice Sancho:

Sin duda que todos los torreones y fosos que mi amo dezía que había en esta venta, los debe él tener metidos en la cabeza... ${ }^{15}$

Éste era el único don Quijote que Avellaneda pudo haber creado. Un autor que se identifica con el "mundo desamorado" sólo puede dar a luz un "Caballero Desamorado".

Como esta nueva locura está basada en una psicología diferente de la del Quijote original, obra también de modo diferente. Se mueve en una sola dirección y se expresa, de manera irregular, actuando sobre el mundo circundante, sin recibir nunca en cambio ninguna impresión. Cuando la fantasía de don Quijote sufre una aceleración, su capacidad de percepción queda cegada a todo lo que lo rodea. Así, como ya hemos notado, no necesita de los engaños de la apariencia, antes indispensable para sostener las decisiones de su voluntad. En una ocasión un alcalde de pueblo, acompañado de la gente del lugar, interroga al falso don Quijote acerca de su extraña apariencia:

Don Quixote... dixo a todos con voz reposada y grave, sin reparar en lo que el alcalde le había dicho:

- Valerosos leoneses, reliquias de aquella ilustre sangre de los godos, que por entrar Muça por España... ${ }^{16}$

15 Quijote apócrifo, pág. 35.

16 Ibid., págs. 185-186. 
Todo lo que necesita don Quijote es un público, y a veces ni eso le hace falta. Una vez comenzado un monólogo, se hace enteramente insensible aun a la más directa interpelación. Sólo una catástrofe física o "puros ruegos" pueden hacerle cambiar de curso.

Hasta en sus momentos de mayor lucidez, don Quijote revela esta incapacidad de percibir. Si se le contradice de tal modo que tenga que hacerse cargo de la contradicción, responderá:

Ahora, pues, andad en hora mala...; que ello será lo que yo digo a pesar de todo el mundo ${ }^{17}$.

Después cambiará de asunto, puesto que una negación como ésa interrumpe la conversación en lugar de dar cabida al diálogo. Esta falta de flexibilidad de don Quijote es reflejo de la falta de problematismo en Avellaneda. Tanto el personaje como el autor sólo pueden admitir dos posibilidades lógicas, lo verdadero o lo falso, el "ser" o el "no ser". El loco escolástico invariablemente se decide por lo falso, pero insiste en su decisión con el mismo dogmatismo con que Avellaneda, "el escolástico cuerdo", sostiene la suya.

Esto, por supuesto, elimina toda imitación de aquellas conversaciones entre don Quijote y Sancho que tanto deleitan en el Quijote original. Al principio consistían estas conversaciones en dos elementos: don Quijote y Sancho empezaban por recordar la última aventura, y en seguida intercambiaban y desarrollaban sus respectivas interpretaciones de ella. Luego, por supuesto la conversación se hace mucho más complicada y sutil, pero aun estos dos sencillos elementos eran imposibles para los personajes de Avellaneda. Sin una voluntad compe-

17 Ibid., pág. 34. 
netrada de vocación, la memoria de don Quijote carecía de criterio que le permitiera convertir los fracasos consecutivos en experiencia. Cada paliza o contradicción estaba aislada de las demás y, en efecto, se olvidaba inmediatamente. Al mismo tiempo, cualquier comentario que Sancho hiciese sobre lo ocurrido quedaba inmediatamente anulado por su dogmático amo. No hay contacto espiritual entre los dos, no hay verdadero diálogo, sino sólo una alternancia de monólogos cómicos. Es evidente que esto hace imposible el mutuo acercamiento psicológico entre don Quijote y Sancho, la “sanchificación" y la "quijotización” que se han notado en el original. Separados para siempre, tienen que fingir el uno ante el otro. Hablando de Sancho, don Quijote define así su convivencia:

- Suplico a vuestra merced, altísima señora, no repare en cosa que le diga este animal, sino que disimule con él, como yo hago, dexándole para quien es, siquiera porque lo habemos menester por estos caminos... ${ }^{18}$

Si Avellaneda se interesaba por las posibilidades del nuevo género, una frase como ésta elimina definitivamente las del desarrollo novelístico del personaje, tanto en el sentido cervantino como en el moderno.

El estilo del nuevo monólogo quijotesco crea a Avellaneda un problema especial: formar material apropiado para la imaginación de su héroe y a la vez evitar la repetición. Lo resolvió variando constantemente los lugares comunes literarios - romanos, troyanos, aragoneses, flamencos - que a cada instante salen de labios de don Quijote. Se suprimieron más o menos los libros de caballerías, y en su lugar se aprovechó todo material

18 Ibid., pág. 231. 
que fuese a la vez legendario y grotesco. Esta solución cuantitativa del problema era la única posible, ya que Avellaneda no podía abandonar el plano único del monólogo. Cervantes, encarado con el mismo problema, pudo servirse, en la Primera parte, de los diversos planos de su obra para insertar vitalmente nuevos esquemas literarios, y pudo inventar, en la Segunda, una aventura extraordinaria tras otra para ilustrar su contrapunto de vocación y desengaño. Pudo en suma crear soluciones cualitativas. En cambio, el falso don Quijote se convierte en una máquina humana que insaciablemente mastica y arroja de sí los temas literarios y militares de su tiempo; y como una máquina, vive sólo en el momento presente, olvida en seguida toda oposición y salta a veces de un discurso fantástico a otro, sin pausa intermedia.

Tal era el loco escolástico, llamado con justicia el "Caballero Desamorado".

\section{EL "Bobo esColástico"}

La extravagancia del Sancho Panza de Avellaneda es distinta de la de su amo. En general, es figura de contornos menos precisos; su estilo no sigue el camino único que caracteriza la locura, sino que cambia siempre que con ello aumenta el efecto cómico. Puede contar chistes con cierto ingenio; puede exhibir su talento de glotón; puede recaer en su cómica simpleza; pero se da cuenta, siempre, tanto de su público como de su propio ser. Sancho es cómico en sí mismo, mientras que don Quijote es sólo cómico por lo que toca a su ilusión, sólo en la medida en que está loco. De hecho, Sancho hace tan bien su papel que al final de la novela un noble de Madrid lo adopta en calidad de gracioso profesional. 
Aunque este contraste refleje a su modo las diferencias entre los personajes del Quijote original, los monólogos del Sancho apócrifo revelan cambios propios de Avellaneda. Lo mismo que su amo, este Sancho incurre en "despropósitos" y no en juicios falsos:

$¡ O h$, reniego de quien mal me quiere y de quien no se duele de mí en tan triste trance! ¿Quién demonios me mandó a mí volver con este hombre..., puesto... a peligro de que si me cogiera la Santa Hermandad me pusiera en cuatro caminos para que después no pudiera ser ni rey ni Roque? ¿Qué haré, pobre de mí?, que estoy por irme desesperado por esos mundos y por esas Indias, y meterme por esos mares, entre montes y valles... tornándome otro fray Juan Guarismas, andando a gachas como un oso selvático hasta tanto que un niño de sesenta años me diga: "Levántate, Sancho, que ya don Quijote está fuera de la cárcel" ${ }^{" 19}$.

Sin embargo, difiere de don Quijote en que sabe que es Sancho. Más que aberración de la razón, es carencia de ella. No es locura, sino simpleza, no una antilógica extravagante, sino necedad. Don Álvaro y don Carlos no tratan de encerrarlo en un manicomio, porque reconocen que "aunque simple, no peligraba en el juicio". Así que cuando Avellaneda crea su propio Sancho, lo contrasta también consigo mismo. Pero es un nuevo contraste: Sancho no es otro "loco escolástico"; es el "bobo escolástico"20.

19 Quijote apócrifo, págs. 67-68.

20 No hay que pensar que la simpleza de Sancho es ignorancia. Es muy capaz de citar frases latinas y de aducir evidentes cultismos, como el "selvático" del pasaje citado. También inserta en su habla numerosas alusiones a asuntos religiosos, a las Escrituras y vidas de santos. El Sancho apócrifo se asemeja mucho menos a su modelo que a ese tipo de la época, el fraile lego de un monasterio. 
Es característico que la diferenciación esencial entre el caballero y el escudero se conservara y a la vez se transformara.

El constante "despropósito" de Sancho tiene, como queda dicho, un estilo menos original que el que resulta del "accidente en la fantasía” de don Quijote. Era frecuente que se usaran pasajes parecidos al citado para producir un efecto cómico, sobre todo en la comedia, donde se les conocía como "bernardinas"21. Por lo común éstas se decían en presencia de

21 Rodríguez Marín reúne gran cantidad de "bernardinas" en su edición de Rinconete y Cortadillo. Ejemplo típico es el siguiente, tomado del Desdén con el desdén de Moreto. Polilla, el intrigante criado disfrazado de "médico gracioso", está hablando con la heroína, Diana:

Diana: ¿Quién entra aquí?

Polilla: Ego

Diana: ¿Quién?

Polilla: $\quad$ Mihi vel mi; scholasticum sum ego, pauper et enamoratus.

Diana: ¿Dónde supisteis de mí?

Polilla: En Acapulco.

Diana: ¿Dónde es?

Polilla: Media legua de Tortosa; y mi codicia, ambiciosa de saber curar después del mal de amor, sarna insana, me trajo a veros, por Dios, por sólo aprender de vos. Partíme luego a la Habana por venir a Barcelona, y tomé postas allí.

Diana: ¿Postas en la Habana?

Polilla: Sí $\quad$ I, 5).

Aunque Polilla prepare estas sandeces con más cuidado que Sancho sus discursos, no deja de haber una semejanza fundamental entre los dos. Ambos representan un concepto contemporáneo de lo cómico. Sancho aun 
un personaje serio cuyo papel consistía en no comprender, para mayor regocijo del espectador. Del mismo modo, el Sancho del Quijote apócrifo requiere siempre un público para sus soliloquios; sin él carecerían de sentido. Don Quijote, en cambio, vive independiente, en su propio mundo antilógico, un mundo que no existe sino en su fantasía, y muchos de sus peores desengaños los sufre cuando está solo, en la cama. Un vuelco de la lógica puede hacerse en soledad, pero una confusión de la lógica sólo puede lograr el efecto cómico que se desea cuando se contrasta con el buen sentido.

Lo único que induce a Sancho a acompañar a don Quijote es, naturalmente, su provecho personal. Cuando el "Archipámpano" (nombre que don Quijote da a uno de sus huéspedes madrileños) le ofrece mejor salario, Sancho no vacila en abandonar a su amo ${ }^{22}$. No bien le persuade Mosén Valentín a regresar a casa - si Sancho carecía de razón, era por lo menos capaz de guiarse por sus dictámenes - , responde:

...no hay remedio con él, sino que quiere que aunque me pese le siga, y para ello me ha comprado éste mi buen jumento, y me da cada mes por mi trabajo nueve reales y de comer; y mi mujer que se lo busque, que así hago yo, pues tiene tan buenos cuartos ${ }^{23}$.

También aquí el valor espiritual que Cervantes había puesto

llega a usar "latín macarrónico", como en el pasaje citado. Dado el carácter de la "bernardina", nada más natural que se tratara de este modo al latín, lengua de tradición, dignidad y congruencia. Si Sancho lo hace con simpleza y el "gracioso" con intención, es porque sus papeles son diferentes, no por una distinción fundamental entre sus estilos.

22 "Archipámpano" es título burlesco tradicional en España. Véase Montoto y Rautenstrauch, Personajes, personas y personillas.

23 Quijote apócrifo, pág. 59. 
en sus personajes se halla amenguado y deformado. Sancho, el "bobo escolástico", es tan "desamorado" como su amo.

Sin embargo, Sancho aún posee un amor positivo: el amor a su asno, que es casi identificación con él. Le llama hermano; pretende hablar "la lengua asnuna lindamente", y mucho más le preocupa la idea de que le puedan separar de su burro que la de una separación de don Quijote. Este tema lo halló Avellaneda en Cervantes y lo deformó a fin de mostrar a Sancho como un ser que, por carecer de entendimiento, era "una bestia". Cuando en Ateca el brutal melonero morisco les roba el asno y Rocinante, Sancho tiene que cargar la albarda. Avellaneda lo describe de este modo:

Començaron a caminar don Quijote con su adarga y Sancho con su albarda, que le venía como anillo en dedo... ${ }^{24}$

Para la mente escolástica, aquella parte del hombre que no era entendimiento era puro "afecto" y equivalía a los instintos e impulsos de un animal. Por eso los amores de Sancho debían permanecer en ese nivel, tal como sus necesidades, su comida, sueño y "buenos cuartos". En el Quijote apócrifo Sancho ama a su asno más que a don Quijote, y el sueño de la ínsula, aunque no desaparezca por completo como el amor a Dulcinea, se relega a alusiones ocasionales.

Otro elemento que hace de Sancho algo más que un bobo estereotipado, que un hombre sin entendimiento, es su cómico localismo. Sancho adora tanto a su lugar como a su asno, y Avellaneda da a entender que ambas aficiones son igualmente absurdas. Sancho divierte a un grupo de zaragozanos con su ardiente defensa de Argamasilla:

24 Ibid., pág. 54. 
- Un lugar es, harto mejor que esta Çaragoça. Ello es verdad que no tiene tantas torres como ésta..., pero tiene las casas, ya que no son muchas, con lindísimos corrales, que caben en cada uno dos mil cabeças de ganado; tenemos un lindísimo herrero que aguza las rejas, que es para dar mil gracias a Dios... Ello es verdad que no tenemos relox; pero a fe que ha jurado el Cura que el primer año santo que venga tenemos de her unos riquísimos órganos ${ }^{25}$.

Cada nuevo elogio jactancioso es tan desatinado que se anula a sí mismo, y el conjunto constituye un cómico monólogo rural de divertida simpleza. Así también, cuando Sancho come solo con el Archipámpano y su mujer, sus modales, de por sí malos, descienden al más bajo nivel de burda rusticidad. El Sancho de Cervantes siempre pudo adaptarse a las circunstancias; nunca se comportó tan bien y con tanta gracia como en compañía del duque y de la duquesa. Pero el personaje de Avellaneda, falto de todo contacto humano con sus huéspedes, obra por contraste y se hace más bestial que de ordinario. En la medida en que es individuo y no un recurso para divertir a la gente, este Sancho vive en su propia "soledad"; tal como don Quijote, se aparta del mundo que lo rodea, en lugar de enriquecer su vida con el contacto. Además de ser "bobo escolástico", Sancho personifica todo el desprecio que Avellaneda sentía por el vulgo; en este caso, por el ruralismo del campesino español.

Para apreciar la enorme distancia que media entre los dos Sanchos, nada mejor que comparar un breve fragmento de las respectivas cartas a sus mujeres:

25 Ibid., págs. 63-64. 
Avellaneda

Habéis de saber que desde que yo salí de Argamasilla hasta agora no nos hemos visto; mi salud dizen todos que es muy buena; sólo me duelen los ojos de puro ver cosas del otro mundo; plegue a Dios que tal sea de los vuestros. Avisadme de cómo os va del beber, y si hay harto vino en la Mancha para remediaros la sed que mi presencia os causa, y mirad por vida vuestra escardéis bien el huertecillo de las malas hierbas que le suelen afligir. Enviadme los çaragüielles viejos de paño pardo que están sobre el gallinero... (ibid., pág. 290.)
Cervantes

Si buenos azotes me daban, bien caballero me iba; si buen gobierno me tengo, buenos azotes me cuesta. Esto no lo entenderás tú, Teresa mía, por ahora; otra vez lo sabrás. Has de saber, Teresa, que tengo determinado que andes en coche... Mujer de un gobernador eres; ¡mira si te roerá nadie los zancajos! Ahí te envío un vestido verde de cazador que me dio mi señora la duquesa; acomódale en modo que sirva de saya y cuerpos a nuestra hija (Quijote, II, XXXVI).

El contraste no puede ser más agudo. El Sancho de Avellaneda escribe, como habla, en una serie de "despropósitos"; en su entendimiento no hay traza de comunión con su mujer ni hay afecto por ella. De hecho, esta carta es otra oportunidad más para que Avellaneda llene la boca de Sancho con estupidez rústica, para que el regocijado público, dentro de la novela, se divierta a su costa. Las alusiones al "huertecillo", al "gallinero", corresponden a esos soliloquios rurales tan cómicos que constituyen el estilo característico del Sancho apócrifo. El contraste de la segunda carta con la de Avellaneda acentúa la magnificencia de la creación cervantina. Aquí el estilo de Sancho puede parecer igualmente desorganizado, pero no lo es en contraste con una organización lógica. Más bien representa el fluir del 
entendimiento no disciplinado de Sancho, que escribe como si hablara directamente a su mujer, a una mujer por la que siente un afecto verdadero. Se acerca algo al desorden del "fluir de la conciencia”. Sancho habla a Teresa, y ambos tienen existencia de seres humanos, valiosos como tal, puesto que él se pone en el plano de ella. Aquí no se trata de monólogo, sino de diálogo, un auténtico diálogo humano. La carta de Avellaneda se dirige sólo al lector; emerge de la novela para divertirlo con su absurdo. El arte de Cervantes, en cambio, no busca al lector, sino que abre una ventana por la que pueda apreciar una dimensión interna del valor personal. El contraste no surge del grado de "realismo" alcanzado por cada autor, sino de su sistema de valores. Uno de los Sanchos existe, es hombre de carne y hueso; el otro es un muñeco cómico, cuyo ser se mide de acuerdo con la hilaridad que es capaz de causar. El uno está solo ante su público eterno, el otro se halla acompañado en la más solitaria de sus aventuras, en la caída a la cueva bajo las ruinas.

\section{LA "SUCIEDAD"}

Ya hemos visto que Avellaneda se interesaba especialmente por aquellas partes del Quijote en que el mundo físico se presentaba en el máximo contraste con el sueño del héroe. Se daba cuenta de que este contraste le servía para acentuar la vanidad y la extravagancia que tanto despreciaba en don Quijote. Por supuesto, estos momentos son raros en la obra de Cervantes, porque su héroe era espiritualmente incapaz de existir en una atmósfera de pura negatividad. El amor épico de don Quijote requería un mundo pastoril, o por lo menos un mundo que no sugiriera a su entendimiento el ridículo humillante, ni a su 
voluntad la crueldad invencible que tanto atraían a Avellaneda. Únicamente en Barcelona es donde una muchedumbre de muchachos callejeros rodea a don Quijote con la "realidad" de la vida, y hay que notar que cuando pasa esto el desengaño final es inevitable. Una situación que anticipa el final de la novela cervantina, que anticipa el retorno de la acción al plano único y estático del escepticismo, se convierte en base y comienzo de la novela de Avellaneda, la cual, por su carácter mismo de historia cómica, nunca ha de salir de ese plano.

Sin embargo, el falso don Quijote se adapta perfectamente a la existencia dentro de ese mundo. Su "desamor", su locura, su capacidad de olvidar le hacen posible, como ya vimos, el andar despreocupado en medio de toda la corrupción y obscenidad con que lo rodea Avellaneda. Continuamente le persiguen las burlas de los pícaros, pero para él no son sino un público, una oportunidad de fingir, y no son fuente de posible desengaño. De hecho, la nueva concepción de don Quijote requiere como complemento un mundo de crueldad prosaica y de "suciedad". El ambiente tiene que compartir la perversidad del individuo; si no, no puede actuar de contraste, no puede dar a don Quijote esos terribles golpes (mil veces más terribles que los descritos por Cervantes) que vienen a acentuar el absurdo de la "confianza en sí mismo". Es importante observar que esta oposición entre don Quijote y el mundo de prosaísmo picaresco, si bien está siempre latente, sólo en determinados momentos o lugares llega a un estado de crisis; en otras ocasiones, como ya hacíamos notar, los encuentros de don Quijote con el mundo exterior eran probablemente más afortunados de lo que se merecía. Pero en los momentos culminantes, Avellaneda, con toda la brutalidad de que era capaz, usó como arma ese mundo exterior que él halló ya configurado en la tradición 
ascético-picaresca y en la Celestina. Los "gargajos verdinegros" que Avellaneda copió de la versión manuscrita del Buscón simbolizan el escenario picaresco que tanto contribuye a originar el "desamor" en don Quijote y a reducir y deformar su valor en cuanto hombre.

En la novela picaresca, tal como la creó Mateo Alemán, el mundo se redimía hasta cierto punto por la introducción de comentarios ascético-morales. La negación del valor mundano se configuraba consciente y artísticamente de modo que pudiera producir el efecto de una parábola. Era una novela neoascética, que confiaba en la significación de su presentación, si no en el mundo que presentaba. En Quevedo, el estilo conceptista pudo redimir su contenido con el valor estético de su efecto desesperado. Pero en el Quijote apócrifo la mundanidad prosaica no va acompañada de comentarios ni de perfección estilística. Siendo algo así como un último producto de la ascética, Avellaneda aceptó como real lo que no presentó como tema de discusión o como medio artístico. Le habían educado en la creencia de que el mundo era "lago de ponzoña", y como tal aparece aquí y allá en sus escritos. El héroe de Avellaneda, inevitablemente "desamorado", puede sólo actuar en un "mundo desamorado" 26 .

26 Los críticos posteriores han atacado duramente este llamado "naturalismo", diciendo que la obra es "desvergonzada" y sosteniendo que, por esta razón, Avellaneda no pudo haber pertenecido a la Iglesia. Pero, como hemos visto, estas cosas pueden atribuirse, al menos en parte, precisamente a ese hecho, a la tradición escolástica y a las décadas de ascetismo que Avellaneda había heredado por ser religioso. Como en el caso de aquel otro eclesiástico, Tirso de Molina, la carencia de amor en el mundo - carencia en que algunos elementos de la Contrarreforma insistieron fervorosamente - dejó como únicos impulsos posibles la pasión animal, el interés propio y la locura. La causa y el efecto de estos pecados se podían predecir con 
Ahora bien, Avellaneda no insistió necesariamente en presentar la suciedad y brutalidad porque las consideraba valores. A pesar de la perversidad que hayamos podido ver en él, no llegó hasta el grado de asociarse con elementos claramente anticristianos y perjudiciales. Aun cuando su mundo picaresco le podía servir eficazmente para subrayar la vanidad de don Quijote, no podía declararse de acuerdo en todo con él. Por lo contrario, dio a esa versión literaria del mundo el mismo tratamiento que dio al caballero y a su escudero. Creó una figura que representaba la suciedad y la ridiculizó junto con los dos antihéroes. En el capítulo XXII Sancho oye gritos desde un bosque, entra en él vacilante, y descubre a una vieja desnuda y amarrada a un árbol. Entre él y don Quijote la rescatan, y ella, personificación de la suciedad, los acompaña en sus peregrinaciones. Por más que se llame Bárbara "la mondonguera" y por más que se dedique a cuantos vicios le permite su edad, don Quijote insiste en identificarla con Zenobia, la casta y hermosa reina de las amazonas. Bárbara tiene una cicatriz en la cara y todos los oficios sospechosos de Celestina; es lasciva aún, y en varias ocasiones trata de seducir a Sancho; es físicamente sucia y de una fealdad extraordinaria; por último, sus vicios la han atontado. El estado lastimoso en que la descubre Sancho es consecuencia de haber escuchado las promesas amorosas de un estudiante. Para Avellaneda esto último era, al parecer, su falta más condenable; Bárbara no recordó el modo como hay que comportarse dentro del mundo de causa y efecto en que vivía. Su simpleza la lleva a dejarse arrastrar a la compañía incier-

mayor facilidad que las inseguras aspiraciones del amor. No eran rivales peligrosos de la Iglesia. Veremos cuán cierto es esto al hablar de los cuentos interpolados. En todo caso, los criterios modernos de decencia no son, probablemente, los más a propósito para juzgar a Avellaneda. 
ta de don Quijote como manifestación pública del vicio y, lo mismo que sus compañeros de viaje, como objeto de risas. Esto aumenta en proporción cuando don Quijote cubre su desnudez con vestiduras llamativas, y por todas partes la da a conocer como la reina Zenobia. Había que adornar el vicio y hacerlo grotesco, para que pudiera resaltar de su medio ordinario y convertirse en parte de la comedia. Bárbara es personificación del mundo de Avellaneda, es un personaje original, y es incapaz de ser "desamorada" porque es el "desamor" personificado.

Así pues, en el Quijote apócrifo no son dos sino tres las figuras extravagantes que recorren los caminos de España; la locura provee el impulso, y la simpleza y la suciedad van detrás. Como en toda comedia, se les retrata como tipos definitivos, ridículos en su acción y en sus monólogos esquemáticos; cada uno representa su particular divergencia de lo comúnmente aceptado. El que Avellaneda introduzca a este nuevo personaje en la compañía de don Quijote es significativo en cuanto que coloca a la "suciedad" del mundo en el mismo plano del individuo desequilibrado con que la contrasta. Indica esto que Avellaneda ha hecho un cambio radical en el básico dualismo ascético. Para los autores ascéticos el valor del venenoso mundo inmanente había estribado en el hecho de que era uno de los términos necesarios del eterno contraste con el cielo. Aunque esto fuera un valor puramente negativo, era sin embargo valor, y como tal lo presentaron los autores de la novela picaresca y los conceptistas. Pero en el Quijote apócrifo este concepto del mundo se presenta sólo esporádicamente (aunque no por eso con menos brutalidad), o se convierte en descarga cómica al lado de un individuo que es incapaz de sacar enseñanzas de él. Don Quijote se resiste tanto al desengaño del mundo como el mundo se resiste a aceptar sus caballerías. Dicho de otra ma- 
nera, para Avellaneda, al parecer, tanto el individuo como el mundo, en la medida en que hay escisión entre ambos, son cómicos. La pretensión de don Quijote y el asqueroso escenario en que la lleva a cabo son igualmente desequilibrados y condenables; el dualismo ascético del hombre frente a un ambiente defectuoso está ahí, pero no se toma en serio. De manera que, como anticipábamos en el primer parágrafo de este capítulo, debemos hallarnos en presencia de un nuevo sistema personal de valores, que tanto al individuo como al mundo circundante los convierte en "figuras" burlescas, y no en actores serios del drama de la salvación. ¿Qué clase de hombres y qué clase de mundo tomaría en serio Avellaneda?

\section{LOS VALORES DE AvelLaneda}

En el curso de un análisis del método que empleaba Molière al escribir comedias, Rousseau hace un esbozo de los principios del género que podrá servirnos de guía para hallar los valores de Avellaneda:

Como tenía que agradar al público, [Molière] consultó el gusto más general de quienes lo componen; sobre este gusto se hizo un modelo, y sobre el modelo, un cuadro de los defectos contrarios, del cual tomó sus personajes cómicos, distribuyendo los diferentes rasgos entre sus comedias ${ }^{27}$.

Darse cuenta de la importancia que tiene el gusto en los defectos del héroe cómico era darse cuenta de que la comedia depende de la polaridad de los valores. Según Scheler, cada valor existe sólo en relación con su opuesto, al cual está íntimamente

27 Jean Jacques Rousseau, Lettre à d'Alembert. 
ligado; la justicia depende de la injusticia, la tosquedad de la elegancia, la armonía de la desarmonía, etc. Cuando el autor y la sociedad que constituye su público aceptan cierto sistema de valores como modelo de corrección, surge instantáneamente un sistema negativo, que, adoptado por un individuo, parece cómico y ridículo. Como observa Rousseau, la comedia se ocupa sólo de valores negativos determinados por la sociedad. Así, los valores de la comedia de Molière son distintos de las virtudes y vicios, es decir, valores inherentes a la vida individual. La glotonería, por ejemplo, es vicio desde un punto de vista, pero desde otro es espectáculo cómico, un polo negativo, no de la moderación, sino de las buenas maneras. De acuerdo con esta definición, la comedia es, pues, un retrato al revés de la estructura de los valores sociales con los cuales el autor se identifica o pretende identificarse.

Si en el caso de la comedia de Avellaneda invertimos la definición y examinamos los tres personajes principales que acabamos de presentar, nos aproximaremos a la jerarquía de valores propia de Avellaneda. Lo opuesto a la caprichosa locura de don Quijote no es la resignación cristiana, sino el reconocimiento de la inflexible lógica del mundo exterior; lo opuesto a la simpleza de Sancho no es la sabiduría filosófica, sino la perspicacia en la interpretación y empleo del esquema lógico; y, finalmente, lo opuesto a la picaresca degeneración de Bárbara no es la limpieza ni la santidad, sino la elegancia y el buen gusto. Cada una de las características cómicas de estos personajes tiene su polo positivo en un valor que se refiere a la conducta social y no a la virtud inherente. Se integran en el retrato de un hombre, no en una lista de cualidades ideales. ¿Cómo es este hombre? Ante todo, se somete enteramente a la estructura lógica del mundo, y está de acuerdo con ella. Sólo manifiesta 
su individualidad cuando emplea su inteligencia para manejar causas y efectos en provecho propio; es perspicaz, pero no suscita problemas de importancia fundamental. Evita las reinterpretaciones personales de su mundo, y rehúye las dudas de la metafísica. En cuanto a su conducta, por último, puede ser pecador, pero nunca es rústico o ridículo; sus acciones son siempre del mejor gusto. De hecho, este hombre es - y con ello confirma la definición rousseauniana de la comedia - un hombre social, en todos los sentidos de la palabra. Vive dentro del esquema de la sociedad, lo apoya, se sirve de él, contribuye a su significación, y no lo niega en un intento quijotesco de dar un sentido personal a la vida. De ahí la gran diferencia que hay entre la comedia de Avellaneda y la tragicomedia cervantina; en esta última, como en toda tragedia, el héroe representa el positivo valor humano justificado en sí mismo y por lo tanto en peligrosa relación con el mundo y con el destino.

Sin embargo, el Quijote apócrifo es más que simple comedia; es también una novela capaz de poner en evidencia los valores de su autor de manera positiva y en múltiples formas. La inclinación de Avellaneda hacia la sociedad, por ejemplo, queda manifiesta a cada instante. El relato de las aventuras de don Quijote en Zaragoza hace que Mosén Valentín diga algo que revela la actitud de Avellaneda:

¡Que me maten si algunos caballeros de buen gusto no han hecho alguna invención de gigante para reír con don Quixote! $!^{28}$

No hay en estas palabras reprobación alguna, ni crítica del cruel y extravagante juego de don Álvaro y don Carlos; estas cosas no son sino muestras de buen gusto, de habilidad social.

28 Quijote apócrifo, pág. 112. 
Tal juicio es, por supuesto, contrario al de Cervantes, quien, prefiriendo los proscritos por la ley a los hombres de sociedad, opinaba que no estaban menos locos el duque y la duquesa al elaborar sus burlas, que don Quijote al dejarse coger por ellas.

Estos "caballeros de buen gusto" se hallan por doquiera en el Quijote apócrifo, y Avellaneda siempre los aprueba. Representan su concepto de la perfección, de la normalidad, y, precisamente por el contraste con esta sociedad, don Quijote, Sancho y Bárbara aparecen como proscritos cómicos. Son esos caballeros a la vez testigos y organizadores de la comedia quijotesca, que es "comedia del mundo", comedia cuyo público figura, al lado de sus personajes, dentro de la novela. El efecto que produce esta presencia del público en la estructura de la trama es, claro está, de importancia decisiva. Ya lo hemos visto: hace de contrapeso a la locura de don Quijote, le obliga a encauzarse de nuevo en el camino regular de la lógica, le proporciona un auditorio para sus monólogos. De don Quijote sale la chispa, y sus empresarios, armados de la necesaria astucia y de su conocimiento de causa y efecto, se ocupan de mantenerla encendida y bajo control. De este modo, don Quijote y Sancho, de proscritos de la sociedad que eran, se convierten en graciosos que están dentro del marco de la sociedad.

A diferencia, pues, de la comedia de un solo plano de que hablaba Rousseau, el Quijote apócrifo, por ser novela, abarca toda la polaridad de cada uno de sus valores. El individuo desequilibrado se contrasta con la sociedad, lo grotesco con el buen gusto, la inestabilidad del loco con la organización estática, y así sucesivamente. Pero cada uno de los términos del contraste existe sólo en función del otro. Los actos de don Quijote carecen de sentido si no los siguen reacciones como ésta: 
Aquí se le agotó a don Álvaro todo el sufrimiento de disimulación que había tenido, y hubo de volver el rostro diziendo:

— ¡Oh, mi don Carlos, y qué paso te pierdes....! ${ }^{29}$

Asimismo, en cuanto personas totalmente representativas de la sociedad, don Carlos y don Álvaro no tienen fuerza narrativa alguna. Juntos, en presencia inevitable el uno del otro, estos dos grupos de personajes opuestos integran el Quijote apócrifo.

Importa en este punto definir claramente la distinción entre los valores y lo que llamaremos por lo pronto la "posición humana”, esto es, la actitud básica ante la vida del individuo. Estamos siguiendo las doctrinas de Ortega y Max Scheler al afirmar que los valores sólo existen en la medida en que el individuo los adjudica a las cosas. En el caso de Avellaneda, se adjudica el valor elegancia a la sociedad, el valor belleza artística al teatro de Lope, etc. Los valores son cosa externa al individuo; él puede estimarlos, apreciarlos, escogerlos, ordenarlos, pero no puede serlos. El conjunto de los valores de un hombre revela su esencia, pero no puede definirla. De hecho, lo que determina la selección de los valores mismos es otra cosa, es un no sé qué que tiene el hombre en sus adentros y que abarca no sólo el carácter fijo, sino también muchas capas de instrucción y experiencia. Así pues, como veremos, Avellaneda podrá adjudicar gran valor a la sociedad, pero su "posición humana” le impide escribir en un estilo que a ella le agrade.

¿Cuál era, pues, la posición humana de Avellaneda, cuál la actitud ante la vida que le hacía seleccionar y ordenar sus valores de la manera que hemos visto? Aunque sólo podemos conjeturar la verdadera personalidad de Avellaneda, la enseñanza ascética que por lo menos en parte le formó nos ayudará

29 Ibid., pág. 105. 
a hallar la explicación que buscamos. La Contrarreforma volvió a organizar el mundo destruido poniendo en lugar de perspectivas inmanentes afirmaciones de orden divino, extrahumano. El mundo se concebía como prueba para el hombre, como mecanismo de causa y efecto en último término inspirado por la divinidad. En el Quijote apócrifo hallamos con frecuencia frases como ésta: "En amaneciendo Dios, se despertó don Quijote...", o "Dios quiso que..." En la larga cadena de las acciones que proviene de Dios - primer motor - se puede ver que cada una de las acciones conduce inmediatamente a otra acción: la equivocación a una paliza, la paliza al crimen, el crimen a la prisión, etc. Del mismo modo, toda ilusión, toda apariencia de realidad, tiene una causa inmediata; tras el monstruo de cartón está el chancero de don Álvaro. De esta ontología postascética, de este neoescolasticismo rígido y simplificado parece estar imbuida "la posición humana" de Avellaneda. Es un hecho que no sólo afecta su estilo narrativo, sino que también parece determinar su selección de valores.

La relación que hay entre esta posible "posición humana" de Avellaneda y su jerarquía social de valores se puede explicar históricamente. Hay que recordar que para los fines de la Contrarreforma, este orden silogístico y algo abstracto resultaba insuficiente en sí. La creencia en el plano divino y en el libre albedrío tendía perversamente a dejar sin cadenas al individuo en el plano mundano. La vida de don Miguel de Mañara y las de los diversos personajes literarios de su especie nos servirá de ejemplo. La conducta piadosa no era necesariamente rasgo típico de aquel contrapuritano, el "caído en la cuenta". No habiendo ya modelo cortesano ni ideal humanista de la "edad de oro" que frenasen las pasiones del individuo por dentro, había que frenarlas desde fuera. Las jerarquías eclesiásticas y sociales, las 
imitaciones humanas de la cadena de mando divina, eran los grandes medios de que se disponía para ello. De hecho estaban más fuertes que nunca; se habían aprovechado de la polémica ascética para hacer más estable su existencia colectiva. De este modo, los herederos naturales y aun inevitables del entusiasmo cuasi épico de los escritores ascéticos fueron las jerarquías estáticas y mundanas de la sociedad y de la Iglesia. Y Avellaneda, impregnado de ortodoxia, halló en ellas sus valores. El antiguo dualismo ascético había sido, como recordaremos, vertical, dualismo de cielo y tierra encaminado a dejar "desengañado" al individuo. Pero una vez logrado esto, el hombre no podía vivir su vida sino colectivamente, organizándola; dudaba ahora del valor y eficacia de las actividades puramente personales. Por ello el dualismo del Quijote apócrifo es, como hemos visto, horizontal, está basado en los valores de la estructura; el individuo se vuelve término negativo, cómico, siempre que niega estos valores, siempre que actúa desde su propio ser. La inversión de la simpatía de Cervantes por el proscrito, el juicio constantemente desfavorable de don Quijote puede, por lo tanto, explicarse como manifestación de la nueva polaridad axiológica del mundo de Avellaneda. Como se le había inculcado el orden divino, Avellaneda sólo adjudicaba valor a las cosas humanas si reflejaban un orden semejante. Así Avellaneda expresó un dualismo nuevo y, como veremos, extrañamente barroco.

Avellaneda admiraba, pues, a la sociedad no sólo por su buen gusto y elegancia, sino también porque imponía la ley de causa y efecto. En una ocasión en que don Quijote ha sido encarcelado, un espectador manifiesta esta típica opinión:

Bien se merece el pobre caballero armado los açotes que le es- 
peran, pues fue tan necio que metió mano sin para qué contra la justicia... ${ }^{30}$

Recuérdese también cómo hace Avellaneda terminar la carrera de don Quijote. El héroe de Cervantes muere de desengaño, cuando se ha derrumbado su sueño; Avellaneda lo entrega a las fuerzas del orden social, al manicomio. Asimismo, a Bárbara la internan en un asilo de ancianos, después de lavarla y vestirla convenientemente. En este tipo de instituciones intervienen a la vez la sociedad y la Iglesia, apoyándose con mutuo esfuerzo. En el siglo xix Avellaneda podría haber sido un buen "burgués", pero en el XVII su creencia se basaba en la ortodoxia social-religiosa, la nueva ortodoxia postridentina. Su odio a Cervantes, su concepto del Quijote original, sus adaptaciones de los personajes, sus lugares comunes ascéticos sin entusiasmo ascético, todo atestigua esta reconstrucción del hombre. Y todo el Quijote apócrifo es expresión de ella.

Los demás valores de Avellaneda, presentes, si bien menos visibles, en su obra, están también de acuerdo con su posición humana. La mayor parte de ellos son de carácter nacional y local, pues aunque Avellaneda no tomó parte en el sueño épico de España, no podía menos de compartir el intenso patriotismo de su tiempo. Pero el suyo era un patriotismo basado en la ya establecida unidad nacional. Avellaneda no parece haber sentido la necesidad de contribuir vitalmente a una unidad que había sido obra - lo mismo que la Contrarreforma - de las generaciones anteriores. No se trata ahora de ningún veterano de Lepanto. Bien reveladora es la explicación que ofrece Avellaneda de los triunfos militares de España:

30 Quijote apócrifo, pág. 68. 
...una de las cosas por donde los españoles son la nación más temida y estimada en el mundo, fuera de su valor y fortaleça, es por la prompta obediencia que tienen a sus superiores en la milicia; ésta los haze victoriosos casi en todas las ocasiones; ésta desmaya al enemigo; ésta da ánimo a los cobardes y temerosos; y finalmente, por ésta los reyes de España han alcançado el venir a ser señores de todo el orbe; porque siendo obedientes los inferiores a los superiores, con buen orden y concierto se hazen firmes y estables, y dificultosamente son rompidos y desbaratados, como vemos lo son con facilidad muchas naciones, por faltarles esta obediencia, que es la llave de todo suceso próspero en la guerra y en la paz $^{31}$.

El valor del esfuerzo personal y de la conquista épica está aquí totalmente supeditado al valor de la organización disciplinada. Aquí se respeta solamente la estructura de causa y efecto que es la premisa de la sociedad militar.

El elogio que hace Avellaneda de las nuevas técnicas de guerra de su época contrasta directamente con el desdén que manifestaba Cervantes hacia todo invento que pudiera amenguar la iniciativa del guerrero individual. En uno de sus monólogos, el falso don Quijote desarrolla este tema:

¿Cuánta es la artillería, coraças y morriones que traen, y cuántas compañías de flecheros?... Presto, Sancho, presto, dilo; que importa para que, conforme a la gente hagamos en este grande prado trincheras, fosos, contrafosos, rebellines, plataformas, bastiones, estacadas, mantas y reparos, para que dentro les echemos naranjas y bombas de fuego, disparando todos a un tiempo nuestra artillería... ${ }^{32}$

31 Ibid., pág. 35.

32 Ibid., pág. 44. 
Era esto la guerra organizada, más cruel quizás que los métodos anteriores, pero sus resultados dependían de la perspicacia militar del capitán, de su habilidad para resolver los problemas estratégicos y tácticos. Se trata de una guerra de causa y efecto, y no de esfuerzo o inspiración individual, y por eso atraía a Avellaneda.

La admiración de Avellaneda por la orden dominicana, manifiesta sobre todo en los cuentos interpolados, proviene de los mismos factores. Como él mismo probablemente era dominico, encomiaba la eficacia con que esa orden lograba inculcar las doctrinas contrarreformistas. Era un ejemplo concreto de ese orden abstracto en que él creía. En cuanto a su simpatía por Aragón ${ }^{33}$, nunca llegó a sobrepasar la lealtad fundamental que sentía para con el marco ideológico de España, para con la lógica de un mundo y de una religión. Para Avellaneda, España no sólo se había hecho defensora de la causa divina, sino que había emulado la ontología divina con sus incomparables organizaciones sociales, militares y eclesiásticas. Y esto fue quizás el verdadero motivo de su admiración por Lope. Aunque Avellaneda mismo carecía por completo del genio creador de Lope, el teatro lopesco infundía grandeza a sus valores. Avellaneda parece haber sido - y si comprendemos esto, muchos aspectos de su "arte" quedan en claro - algo así como el posible común denominador del público de la comedia.

\section{El ESTILO NARRATIVO}

Ya hemos visto cómo los estilos personales de don Quijote y

33 Un estudio más completo de esta doble lealtad podrá verse en mi ya citado artículo, "Alonso Fernández de Avellaneda, a reconsideration and a bibliography”, HR, XIV, 1946, págs. 304-321. 
de Sancho son esencialmente ajenos a Avellaneda, cómo su significación proviene de que expresan los antivalores del autor. Aun queda por estudiar el estilo de Avellaneda mismo, el de los pasajes descriptivos y narrativos de su obra, en que no intentaba personificar una actitud opuesta a la suya. Para que nuestra hipótesis quede en pie, este estilo deberá abarcar los polos positivos del sistema de valores, deberá ser un estilo casi matemáticamente opuesto al de sus protagonistas, aunque concebido en los mismos términos.

Un ejemplo típico del estilo descriptivo de Avellaneda es el siguiente. Alguien acaba de aconsejar a don Quijote y sus compañeros de viaje que descansen a la sombra de una arboleda, durante el calor del mediodía:

A lo cual respondieron ellos con muestras de gusto, que le tendrían grandísimo en gozar de tan buena compañía las cuatro o cinco horas que allí pensaban estar; y uno dellos, maravillado de ver aquel hombre armado de todas pieças, preguntó al ermitaño al oído qué cosa fuese, a lo cual respondió que no sabía otra cosa más que cerca de Çaragoça había topado con él y aquel labrador su criado, hombre simplicísimo, y que, a lo que imaginaba, se había vuelto loco leyendo libros de caballerías, y con aquella locura, según estaba informado, había un año que andaba de aquella suerte por el mundo, teniéndose por uno de los caballeros andantes antiguos que en tales libros se leen ; y que si quería gustar un poco dél, que le diese materia en asentándose allí, y oiría maravillas. En esto llegaron a ellos don Quixote y Sancho que habían estado quitando el freno a Rocinante y la albarda al rucio, y después de haberse saludado todos, le dixo uno de aquellos canónigos que se quitase las armas porque venía muy caluroso, y allí estaba en parte segura, donde todos eran amigos ${ }^{34}$.

34 Quijote apócrifo, pág. 115. 
Avellaneda escribe este párrafo para preparar uno de los soliloquios en que habla la locura de don Quijote; por ser, pues, escenario, carece de movimiento narrativo y evita todo diálogo. Este estilo indirecto es uno de los rasgos fundamentales de la prosa de Avellaneda. Cuando no se ocupaba de los extravagantes monólogos de don Quijote y Sancho, Avellaneda tenía dificultad en inventar una conversación para sus personajes. El diálogo requiere - lo repetimos - un intercambio de puntos de vista o por lo menos de deseos, y siendo los personajes no extravagantes de Avellaneda ejemplos rutinarios de un único esquema de valores fijos, no había diferencia personal entre ellos. No es necesario que los personajes de importancia secundaria desborden ocasionalmente en monólogos; no hace falta que hablen en absoluto. Algo del anonimato de Avellaneda se les había pegado.

Esta preparación narrativa está escrita con una monotonía no aligerada por ningún recurso estilístico. En la primera frase hay un caso de zeugma (el le se refiere al gusto, que aparece en la frase anterior), pero hasta esta decoración rudimentaria es rara. El estilo intenta solamente expresar la construcción lógica de los acontecimientos y evita por tanto todo ornamento que pueda distraer. Cada uno de los acontecimientos está contenido en una cláusula que se une en secuencia con otras, por medio de conjunciones apropiadas. Nótense las frases subrayadas del párrafo citado. Es un compendio intelectual de todo el material pertinente, y no una selección artística de él. Se nos informa acerca de los detalles más insignificantes: sabemos por qué don Quijote y Sancho no están presentes en la plática sobre ellos; estamos perfectamente enterados de lo que están haciendo entre tanto. A todos los acontecimientos parece que se les da la misma importancia. Como Avellaneda se identificaba con el 
mundo ya reconstruido, carecía de perspectiva para juzgarlo; podía presentarlo como historiador, pero no podía acentuar o eliminar, como hace el artista.

No hay aquí, claro está, el menor dejo de conceptismo ni de culteranismo. A Avellaneda parece satisfacerle el marco lógico de su mundo. No siente la angustia de una mediocridad estilística, ni el deseo de poseer su estilo en apasionada protesta o de escapar en él. Tales salidas por la tangente quedan, según él, para el quijotismo, y deben eliminarse o rechazarse, pero nunca resolverse en la curva barroca.

Para permanecer dentro de ese estilo, Avellaneda debía considerar necesariamente el tiempo, esto es, la secuencia temporal de causa y efecto, como algo absoluto e invariable. La manera como don Quijote describe sus aventuras de Zaragoza revela a las claras este rasgo del estilo de Avellaneda:

Y tomando la mano don Quixote para responderle, contó punto por punto lo que en Çaragoça les había sucedido con el gigante en casa de don Carlos ${ }^{35}$.

Así, punto por punto se va amoldando el estilo al esquema de los acontecimientos; rehúye la metáfora y cuantos recursos poéticos puedan abstraer del tiempo la cosa descrita y llenarla de significación. Avellaneda nos aleja igualmente del torrente de Zárate y del manso arroyuelo de Garcilaso. A él no le interesa ya el ritmo del tiempo a través del individuo; le importa sólo el exterior inexorable, la geometría inevitable de causa y efecto a la que sirve de medio. Pero Avellaneda no insistió en el tiempo en este sentido; no insistió, como Tirso en el Burlador de Sevilla, en la lección que se desprende del paso del tiempo; para él

35 Quijote apócrifo, pág. 112. 
era obvio. Las cómodas “cuatro o cinco horas” del pasaje citado son uno de los muchos ejemplos de cómo Avellaneda no logra considerar el tiempo como problema, e ignora las oportunidades artísticas que alberga.

En varias ocasiones, claro está, Avellaneda trata de dar a su historia cierto brillo literario. Esto ocurre generalmente al principio de un capítulo, en que el autor tiene cabal conciencia de las exigencias peculiares de su trabajo; por lo común ese brillo consiste en cierta ordenación o sustitución artificial de palabras. Muestra preferencia, como las novelas pastoriles, por el adjetivo antepuesto. El afectado giro "rojo Apolo", por ejemplo, lo imitó Avellaneda del original debido a su ingenuidad literaria. Un intento más revelador aún de su afán de dar elegancia a su estilo es la primera frase del capítulo XIII:

Atormentaron tanto las traças de la desvanecida fantasía del desamorado manchego su triste juizio y desvelado sosiego, que cuando empeçaban sus ojos a tomar alguno a la madrugada, tocaron al arma de tal suerte las fantasmas de los dislates quimereados en el sentido común, que siéndolo en todos sus miembros la alteración que por esta causa, y la que dio con ella un sueño que tuvo de que había entrado por traición en aquel castillo el soberbio Bramidán para matarle... como si realmente supiera que estaba en casa... ${ }^{36}$

Al principio el autor emplea el complicado zeugma, se sirve de frases tan elegantes como "desvanecida fantasía”, y llega a inventar un eufemismo para don Quijote: "el desamorado manchego". Pero hacia la mitad de la frase el estilo comienza a decaer, se introducen conjunciones, y con ello quedan restablecidas las relaciones causales. Los adjetivos vuelven a su posición ordinaria en el momento en que Avellaneda comien-

36 Ibid., pág. 99. 
za a distinguir entre lo real y lo irreal, y en que la necesidad de describir cabalmente su "realidad" vuelve a ser la primera de sus preocupaciones. El elevado e intencionado comienzo no llega a ocupar más de tres o cuatro líneas, después de las cuales lo ordinario regula de nuevo el estilo ${ }^{37}$.

Esta división del Quijote apócrifo en dos estilos fundamentales, lógico el uno y el otro ilógico, usado el uno cuando escribe para sí mismo y el otro cuando escribe para sus personajes cómicos y antiheroicos, no sólo confirma nuestra reconstrucción de las ideas y valores de Avellaneda, sino que también hace entrever que la obra se divide en capas alternativas de historia y comedia. A diferencia de Cervantes, Avellaneda era incapaz de fundir un plano estilístico con otro; las categorías rígidas tienen que estar rigurosamente separadas. De modo que si su don Quijote puede llamarse "loco escolástico", el estilo define de nuevo a Avellaneda como "cuerdo escolástico". Es un estilo que parece surgir espontáneamente de todos los eslabones lógicos del pensamiento y del ser de su autor. Por ello es un estilo que da por sobreentendido el tiempo, juega torpemente con el ornamento y halla su expresión más sublime en la gramática. Una vez más cabría perfectamente el adjetivo "desamorado".

37 Es importante hacer notar que, a pesar del valor que Avellaneda ve en la sociedad, no es capaz de escribir en un estilo social, es decir, en un estilo que guste a la sociedad, como fue capaz su admirado Lope aunque fingía desdeñarlo. Como decíamos en el párrafo anterior, Avellaneda selecciona y crea sus valores de acuerdo con las posibilidades exteriores, pero él no "es" sus valores. Así, emplea "el rojo Apolo" porque le parece frase elegante, pero es incapaz de usarla acertadamente. Esto nos dice, entre otras cosas, que Avellaneda era un diletante de las letras, que carecía de facultades para adaptar el estilo que expresaba su "posición humana" a los valores que esa posición había adoptado. Es esto una manifestación casi indudable de infantilismo artístico y podrá ayudar a identificar al desconocido autor. 


\section{LAS NOVELAS CORTAS INTERPOLADAS}

Fiel a la forma cervantina, Avellaneda interpola dos cuentos en el Quijote apócrifo. Sin embargo, la imitación no se extiende al contenido, puesto que estos cuentos no tienen nada que ver con los de la Primera parte del Quijote. No son tampoco originales de Avellaneda; su asunto proviene de la tradición europea, aunque están presentados, como era de esperarse, de acuerdo con lo que ya sabemos de Avellaneda. Esto nos presenta una nueva serie de problemas críticos, puesto que el cambio de fuentes implica un cambio correspondiente en el método de imitación. A lo largo del Quijote apócrifo Avellaneda imitó una técnica narrativa, un esquema de acción que lo dejaba en libertad para hacer variaciones individuales. Pero en estos cuentos utilizó más bien una trama determinada que no daba marco más que a una reforma de estilo e interpretación. En el primer caso la imitación llega a dejar al descubierto por completo su posición humana; el segundo da por resultado la expresión consciente de un sistema fijo de ideas.

Por una parte, relación implícita en que el autor se convierte en sustancia de todo un mundo; por la otra, relación explícita en que el autor trata de aplicar varias de sus ideas conscientes a un marco preestablecido. En los cuentos interpolados Avellaneda pasa, pues, de la novela o presentación del mundo a la novela ejemplar o presentación de ideas.

Este cambio en el método de imitación puede definirse aún con mayor precisión. En realidad se trata de un cambio a ese segundo tipo de imitación de que hablábamos antes, la imitación "a lo divino". Ante el problema de volver a escribir un cuento ya existente, Avellaneda, como es de esperarse, recurre conscientemente a su tradición ideológica, al cuerpo de 
doctrina que tenía más presente en su espíritu: el de la Contrarreforma. En todo el Quijote apócrifo lo que conscientemente había buscado eran nuevos sucesos y aventuras para llenar su historia y dar base a su comedia; pero lo que necesitaba ahora, en las novelas cortas, eran ideas para reelaborar los sucesos que tenía a la mano. La fuente más natural para estas ideas era su enseñanza ascética. Ahora bien, ¿de qué modo se expresará la "posición humana" de Avellaneda dada la nueva construcción narrativa? ¿Y de qué modo cambiarán las ideas y técnicas ascéticas cuando las expresa un autor que ya no las siente vitalmente? Éstos son los problemas que se presentan en cuanto se examinan los cuentos interpolados.

El título de los cuentos - Los felices amantes y El rico desesperado - indican ya su orientación y hacen entrever la intervención directa de lo divino en lo humano, sobre todo en los placeres y riquezas mundanos. El pecado individual no se castigará ya con la risa de los hombres o con una prisión impuesta por la sociedad, sino con una acción directa del cielo ${ }^{38}$. Esto era de esperarse; pero ¿en qué forma desarrolló Avellaneda el conflicto entre la divinidad y el hombre descarriado? Un soldado que regresa de Flandes cuenta la historia del Rico desesperado, que es un joven de Lovaina llamado "monsieur Japelin". Después de haber oído un sermón de un fraile dominico, Japelin se hace novicio de la orden, y lleva una vida irreprochable. Pero dos amigos suyos, "sospechosos de la fe" (es posible que Avellaneda se refiera aquí al protestantismo), le ponen por las nubes los placeres y honores que le esperan en el mundo, y con ello lo inducen a abandonar la vida monástica. Japelin no ha

38 Desde el punto de vista de la identidad de Avellaneda, es curioso que en los dos cuentos la orden dominicana es la que representa el plano divino. 
profesado todavía en su orden y está en libertad de abandonarla; no presta, pues, atención a los argumentos del prior, que le advierte que va a regresar a la "confusión del siglo". Al ver el prior que Japelin se mantiene firme en su decisión, le advierte:

Acordaos... hijo, que me habéis oído dezir cómo hasta hoy ninguno dexó el hábito que una vez tomó de religioso, que haya tenido buen fin; que justo juizio es de Dios que quien siendo llamado por su divina vocación a su servicio, si después le dexa de su voluntad en vida, que el mismo Dios le dexe a él en muerte... ${ }^{39}$

El fraile predice, pues, que perderá su alma, pero a pesar de eso Japelin abandona el monasterio, y, sin que él lo sepa, le espera la venganza de un Dios celoso. En la vida mundana Japelin es un buen ciudadano y de ninguna manera un pecador; se casa, ama a su esposa, se ocupa de sus propiedades y se muestra caritativo con todos. Sin embargo, un soldado español al que había hecho mucho bien, se vuelve instrumento de la venganza divina. Fingiéndose Japelin, y ayudado de la oscuridad, el soldado seduce a la mujer, recién parida; el suceso termina con el suicidio de Japelin y su esposa. El castigo es, claro está, la condenación eterna. El lector dirá que Japelin es más bien mártir que pecador; pero Avellaneda parece ver un pecado mortal en preferir el mundo a la orden dominicana ${ }^{40}$.

Avellaneda ha llevado aquí la lógica de la enseñanza ascética a su último extremo, puesto que al mundo se le dan todas las ventajas posibles en su contienda con el cielo, y sin em-

39 Quijote apócrifo, pág. 119.

40 A pesar de numerosas investigaciones, no ha sido posible descubrir la fuente literaria de este cuento. Algunos críticos han sugerido que es adaptación de un suceso real. Lo único que se puede afirmar con plena certeza es que Avellaneda no lo inventó. 
bargo el partidario del mundo resulta condenado. Desde un punto de vista ético no hay motivo para la condenación; pero como su amor al mundo lo hizo desdeñar el llamamiento divino, Japelin es destruido. En sus ataques más acerbos contra el mundo inmanente, Zárate y Fray Luis de Granada tuvieron buen cuidado de mencionar los diversos pecados mortales en él implicados; en ninguno de ellos incurrió Japelin. Los escritores ascéticos, interesados sobre todo en convertir, no llegaron al extremo de hacer parecer injusto a Dios. Muy al contrario, se preocuparon de dar al mundo el aspecto de un arsenal de vicios y corrupción. Pero Avellaneda, con su capacidad de atenerse estrictamente a la causa y efectos lógicos, no siguió por este camino. Establece el dualismo de cielo y tierra y llega a la conclusión inevitable de que aun la decisión por las cosas más virtuosas de la tierra, si por ellas se deja el cielo, no tiene perdón.

La lección complementaria la da el cuento de los Felices amantes. Aquí se trata de la monja pecadora reemplazada por la Virgen, milagro tradicional en España, desde los tiempos de Berceo. Doña Luisa, priora de un convento, huye secretamente de él y vive una vida de degradación mundana en compañía de un libertino, llamado don Gregorio. Cuando por fin se arrepiente, se encuentra con que la Virgen ha ocupado su lugar para que ella pueda recuperar su puesto y salvarse. La gracia concedida a doña Luisa es otra derivación lógica del dualismo de la Contrarreforma. Doña Luisa comete una serie de pecados; luego se arrepiente; y esto cabe perfectamente en la estructura del catolicismo especial de Avellaneda. A diferencia de Japelin, su amor por el mundo es carnal. Por eso doña Luisa no arroja a Dios de su alma, sólo lo desobedece, y cuando retorna a la obediencia, puede ser absuelta. Avellaneda describe su huida del convento de este modo: 
...al salir della por delante de un altar de la Virgen benditísima, de cuya imagen era particular devota, y le celebraba todas las fiestas suyas con la mayor solenidad y devoción que podía, a la que llegó delante della, se hincó de rodillas, diziendo con particular ternura interior y notable cariño de despedirse della, privándose del verla, porque era la cosa que más quería en esta vida:

- Madre de Dios y Virgen purísima... ${ }^{41}$

En seguida Doña Luisa se lamenta por la pecadora vida que la espera, y reza por el bien de las monjas que le estaban encomendadas. La monja cede, pues, al mundo contra su voluntad, consciente, no de que ha obrado bien, sino de los vedados atractivos del pecado y de la tentación. Su abandono de la vida monástica no niega, como el de Japelin, la necesidad de la Iglesia o la importancia inmediata de Dios para el hombre. Y por ello, aunque sus pecados (también a diferencia de Japelin) fueron muchos y horribles, doña Luisa se salva.

Los felices amantes es, pues, una obra paralela al Rico desesperado; presenta la otra fase de la interpretación que Avellaneda daba al pensamiento ascético. Juntos los dos cuentos interpolados constituyen una íntegra profesión de fe. La salvación no dependerá de que se haga el bien o el mal, sino de la actitud que el individuo adopte frente a estas acciones buenas y malas y frente al mundo en que las ejecuta. El más ferviente polemista de la Contrarreforma probablemente no habría adoptado una actitud tan extrema. A pesar del Condenado por desconfiado, la condenación de don Juan muestra que, enfrentado a un problema parecido, Tirso no lo resolvió como Avellaneda. Estas dos situaciones constituyen la más ardua prueba ética a que se puede someter el dualismo ascético, y éste, por la invariable ne-

41 Quijote apócrifo, pág. 144. 
cesidad de su lógica, sale triunfante. Es la victoria de la lógica sobre el sentimiento y aun sobre la razón.

Si comparamos la doctrina de estos cuentos con el argumento ascético, tal como lo hallamos en los escritos de un Zárate o de un Fray Luis de Granada, nos llama la atención en seguida no sólo la culminación lógica del dualismo original, sino también el hecho de que la campaña ascética ya se había hecho histórica. Los apasionados gritos de guerra del gran impulso épico contrarreformista se estaban haciendo lugar común. Habían abierto el camino hacia un mundo desengañado, hacia un mundo nuevamente organizado, y como veteranos después de la victoria, habían perdido, si no la popularidad, sí el sentido de su vocación. Al contrario de Calderón, que fue capaz de reasir lo que había de poético en el argumento ascético, Avellaneda se sirvió del pensamiento ascético como de una verdad tan evidente que él podía, hasta cierto punto, darla por supuesta. Así se explica la presencia prosaica y parcial de estos temas a lo largo del Quijote apócrifo y, en las novelas interpoladas, la insistencia en estas últimas consecuencias lógicas. Quizás parecería demasiado paradójica la frase "ascetismo desamorado"; pero al menos podemos afirmar que con Avellaneda el ascetismo había perdido la pasión y la necesidad humana de su odio. Se había vuelto una doctrina alarmante por su injusta lógica mecanizada.

Aunque aquí Avellaneda modifica el pensamiento ascético de acuerdo con nuestra interpretación de su idiosincrasia espiritual, la nueva introducción del dualismo vertical le obliga igualmente a modificar sus preferencias y valores. Tomemos como ejemplo el pasaje en que don Gregorio corteja a doña Luisa, de acuerdo con el concepto alambicado y un poco ingenuo que Avellaneda tenía de la galantería y del discreteo cortesano: 
_...de aquí adelante pretendo mirar por mi vida, para tener siquiera qué emplear en servicio de quien tan bien sabe dármela cuando menos la confío; y porque acabe de conocer, proseguirá vuestra merced el hazérmela, quiero atrevidamente pedir otra de nuevo, confiado en lo que acaba de dezir, de que gusta de mi vida...

-...Sin duda, dixo ella, que debe de ser, según se le haze de mal el dezirlo, algún pie de monte de oro.

- No es, respondió don Gregorio, sino una mano de plata (que tales son las blanquísimas de vuestra merced), para besarla por entre esta reja ${ }^{42}$.

Ahora bien, cuando don Álvaro, don Carlos y los demás personajes nobles del Quijote apócrifo intercambian cortesías, tales sutilezas no hacen sino confirmar su "buen gusto" social, contrastado con el grotesco don Quijote y el rústico Sancho. Pero en Los felices amantes, Avellaneda designa con otro nombre este para él refinadísimo trato social: "desenvoltura”.

En los cuentos interpolados, claro está, no hay un antihéroe que se oponga a la sociedad ni surge ninguna tensión exterior debido a imposibles acciones de personajes impenetrables. El dualismo, por lo tanto, no es ya horizontal, entre el individuo y el mundo, sino vertical; es el encuentro y el choque de cielo y tierra dentro del individuo. Hay más bien una tensión interior cuando el individuo trata de resistir las "baterías" de la tentación mundana. De ahí que Avellaneda tenga que rechazar todos los aspectos del mundo; la base ascética de sus cuentos desecha la menor distinción de valores en las cosas mundanas. Desde el punto de vista del individuo que titubea entre la salvación y la condenación, la sociedad con su trato era una tentación peligrosa. En cambio, desde el punto de vista de

42 Ibid., pág. 141. 
la organización del mundo, de la relación colectiva del hombre con Dios, era necesario que la sociedad tuviera el mayor prestigio posible. Así, aunque don Álvaro Tarfe y don Gregorio son en esencia el mismo personaje, están vistos a través de dos prismas de diversos ángulos estéticos y morales.

Asimismo, a través de estos prismas, la dimensionalidad y los atributos del mundo quedan transformados. En lugar de adaptar el estilo a la inalterable secuencia de los sucesos, Avellaneda acelera ahora el tiempo, a fin de acentuar la vanidad de las aspiraciones mundanas de sus protagonistas. Vuelve de nuevo al contraste ascético del tiempo con la eternidad. En consecuencia, debe también afirmar la vanidad de toda fiesta mundana, vanidad en que no se piensa al leer, por ejemplo, la entusiasta descripción del torneo de Zaragoza. Estos cambios dejan entrever, otra vez, el porqué de la fascinación que Avellaneda sentía por la fórmula del Quijote. El género de la novela ejemplar no le permitía expresar su ser auténtico en un estilo; no podía dar expresión a la nueva visión del mundo que su educación había creado en él (como lo hace en la mayor parte del Quijote apócrifo), sino sólo repetir y exagerar las enseñanzas de esa educación. Lo mismo que Quevedo y otros autores barrocos, Avellaneda se vio impelido a superar los orígenes ascéticos de su visión de la vida. La novela había cautivado a su exponente más genial, Cervantes, como medio a propósito para la libertad artística, y quizás lo que a la vez atrajo y rechazó a Avellaneda en el Quijote fue el hecho de ser novela. El Quijote pertenecía a un género que dio a Avellaneda la libertad de expresar cuán satisfecho se sentía con su prisión. 


\section{LA GEOGRAFÍA LITERARIA}

El Quijote apócrifo, repetimos, es una obra extraordinaria dentro de la literatura del Siglo de Oro. Se sirve de la técnica novelística cervantina, y sin embargo rechaza la visión de la vida que había hallado expresión en esa novela y que volvería a hallarla en otras. Revela gran admiración por la estructura social de su tiempo, y sin embargo, su estilo llano y lógico no podía aspirar a la aceptación social. Pero su paradoja más fundamental es quizás el que sea expresión del dualismo barroco y carezca de la correspondiente complejidad angustiada de expresión.

En la Introducción ya observamos con detalle que el barroco es resultado del tránsito del dualismo vertical fomentado por la Contrarreforma al dualismo horizontal del estilo, y vimos que el barroco puede considerarse expresión estética de la Contrarreforma. Las dos tendencias estilísticas más importantes del barroco, conceptismo y culteranismo, expresaban, como dijimos, la nueva visión que el individuo tenía del mundo circundante, amputado de él después de la Contrarreforma. Una vez perdido su enlace con la vida, el individuo recurría a la intensificación de un sustituto literario. Quevedo escribió en términos de "soledad”, lo mismo que Góngora. Como dice Castro:

Algunos autores del siglo XVII insistieron en ciertos temas favoritos: la crítica de la sociedad y la huida de ella en busca de una paz y una soledad inalcanzables... En todo caso, hacia esa época existían ya los "raros", es decir, los escogidos, los aislados. Entre ellos se encuentran, sin duda, Góngora, Quevedo y Gracián. Su ansia de inconformidad está desnuda y a la vista, sin poder objetivarse en ningún sistema de principios ni en posiciones básicas y firmes. La consecuencia fue que este deseo de soledad, este 
afán de distinguirse de los demás, de ser "raro", se sublimó en los nuevos y complejos estilos de un arte extraño y solitario ${ }^{43}$.

Así, el dualismo barroco se enfocaba por lo común desde el individuo; éste se daba cuenta del dualismo; lo vivía y el dolor que le causaba salía a la luz en su estilo. De esta manera los estilos barrocos nacieron de la herida abierta por la revelación ascética; pertenecían a poetas que no querían curar su existencia con el único remedio posible, la reorganización externa y lógica, la fe seca en la sociedad y sus instituciones.

Pero, como anticipábamos antes y ahora podemos afirmar, en el Quijote apócrifo el dualismo barroco se presenta desde un punto de vista opuesto, el de la sociedad, que representa el mundo nuevamente estructurado. Es quizás la única obra de la época que lo consigue plenamente, tanto en la trama como en la construcción y en el estilo. Por lo común los artistas o son disidentes o son intérpretes de su ortodoxia cultural; rara vez se limitan a trasmitirla. De hecho, para Avellaneda el otro término del dualismo es el llamado "raro", puesto que consiste en la extravagante y antisocial locura de su don Quijote. Todos los rasgos que hemos observado en la novela nos llevan directamente a esta conclusión: Avellaneda escribía desde el punto de vista colectivo, y por lo tanto es justo que haya quedado anónimo.

¿De qué manera revela el Quijote apócrifo el otro lado del tapiz barroco? ¿De qué modo se corresponden los rasgos negativos del barroco de Avellaneda con los positivos, digamos, de Quevedo? Ya hemos aludido a algunas de estas correspondencias; reunámoslas ahora para confirmar definitivamente la

43 A. Castro, Introducción a The poetry of Jorge Guillen, Princeton, 1942, pág. xv. 
latitud y la longitud literaria que hemos asignado a Avellaneda. Para Quevedo el mundo era una serie de apariencias, un "parecer", cuya realidad él ponía en duda y destruía. De ahí que los continuos ataques contra el mundo rompan a cada instante el hilo de la narración. Avellaneda, en cambio, no ataca al mundo, sino al individuo disidente; hace responsable del dualismo al perverso "fingir" de su héroe, y nunca al perverso "parecer" del mundo. En ambos casos la armoniosa progresión narrativa, esencial al arte de Cervantes, queda interrumpida; pero el método de Avellaneda no consiste en monstruosidades antilógicas, en engaños o "conceptos", sino en repentinas y desequilibradas explosiones discursivas, cada una de las cuales se aleja por un sendero arbitrario del camino de la novela. El dualismo se aniquila tan pronto como surge, con un inmediato castigo lógico. La insistencia de Avellaneda y los conceptistas en el dualismo presenta a uno y a otros el mismo problema estético, pero cada uno lo resuelve de acuerdo con su punto de partida. Avellaneda ridiculiza y castiga todo brote de expresión individual por medio de un contrataque colectivo de la muchedumbre de "enterados" que presencian las extravagancias de don Quijote. El poeta "raro", en cambio, intenta corregir la futilidad de su acción aumentando la eficacia estilística de su expresión. Los monólogos cómicos y grotescos ("góticos" según Avellaneda) de don Quijote corresponden a la conciencia trágica que se alberga tras el ingenio del "concepto", tras el cristalino escape de la metáfora cultista, que son en realidad monólogos, en el sentido más cabal de la palabra.

Este alejamiento continuo de la progresión, característico de Avellaneda y del artista comúnmente considerado barroco, da como resultado ciertos paralelismos en la pintura del medio ambiente y también en la estilización de las reacciones 
humanas. En ambos hay, por ejemplo, una tendencia al exceso de decoración ${ }^{44}$. Avellaneda sentía marcada preferencia por los aspectos puramente ornamentales de la vida, sobre todo de la vida social. En su descripción del torneo de Zaragoza introduce largas e inútiles enumeraciones de "emblemas" y "enigmas" ${ }^{5}$. Esto sólo en parte se debe al hecho de que, para el autor, todo dentro de la obra tiene igual importancia, de que, como "historiador", no hace una selección artística de los hechos. Capaz, gracias a este concepto, de pasearse a sus anchas por el mundo de las cosas, describe lo superficial de acuerdo con los dos aspectos que más atraen su atención: lo elegante y lo obsceno. Esto es, claro está, rasgo básico del barroco. Es lo que queda del mundo cuando de él se desprende la integrante

44 Remitiendo una vez más a la Introducción, quisiéramos recordar que esta tendencia surgió como corolario del ataque ascético y que más tarde, al perder su impulso doctrinal, se hizo característica del arte barroco. El aspecto superficial, lo elegante y lujoso de la vida, contribuía a negar, con su pura existencia, la significación de la experiencia mundana del hombre. Eran instrumentos de desengaño. Cuando este principio se aplicaba, por ejemplo, a la arquitectura, lo que resultaba eran fingidos balcones en bajorrelieve, hábilmente simulados, o una superabundancia de complicadas decoraciones en todas las superficies abiertas.

45 Encontramos pasajes semejantes, por ejemplo, en los Cigarrales de Toledo de Tirso. A la posible objeción de que, al reproducir las poesías recitadas en las bodas de Camacho, Cervantes se hacía eco de esa tendencia, él mismo replica: “...cada uno hizo... sus versos, algunos elegantes y algunos ridículos, y sólo tomó de memoria don Quijote (que la tenía grande) los ya referidos..." De este modo, asimila los versos al ser y a la memoria de su don Quijote. Se incluyen en la corriente vital del héroe, y con ello no son ajenos al curso de la narración. El "Caballero desamorado", en cambio, es incapaz de retener una derrota acaecida poco antes, y mucho menos los versos que le llamaban la atención. 
fuerza del amor, cuando la escisión barroca desgaja al hombre de su propia vida.

La falsa apariencia y el ilusorio juego del "engaño a los ojos" también aparecen en el Quijote apócrifo, pero están igualmente desfigurados por la visión particular que Avellaneda tenía del dualismo. La batalla de don Quijote con el gigante Tajayunques nos servirá de ejemplo:

Hízose... dos pasos atrás, y, sacando la espada medio mohosa, se fue poco a poco acercando al gigante, el cual, viéndole venir, fue prontísimo en sacudir de sus hombros la aparente máquina de papelón que sobre sí traía, en medio de la sala, y quedó el secretario que la sustentaba, vestido riquísimamente de muger; porque era mancebo y de buen rostro, y, en fin, tal, que cualquiera que no le conociera se podía engañar fácilmente. Espantáronse todos los que el caso no sabían ${ }^{46}$.

Esto no es falsa apariencia, sino embuste, embuste que se hace para divertir a "los que sabían el caso". Es un juego de salón realizado en una reunión social, no una estilización de la angustia del individuo al que se ha engañado. Una vez más se trata del "fingir", no del "parecer".

Así, pues, hablando en términos puramente literarios, podría decirse que la obra de un Quevedo se compuso en reacción apasionada contra lo inevitable del mundo, tal como se refleja en la novela de Avellaneda. El Quijote apócrifo revela, en cuanto obra barroca, la condición vital detrás de los excesos estilísticos que caracterizan al conceptismo y al culteranismo. De hecho, cada una de las manifestaciones estilísticas del barroco sólo se puede comprender en relación con las demás.

Si los grandes estilos desesperados habían de perder defi46 Quijote apócrifo, pág. 282. 
nitivamente la pasión de su impulso y reducirse a decoración rococó, si la desesperada lucha del barroco había de ceder en tensión y con ello limitar la expresión artística a un único plano de superficialidad visual (tendencia cuyos comienzos se manifiestan por doquiera en el barroco), ¿qué clase de futuro literario podía tener ese tipo de barroco que representa el Quijote apócrifo? Porque sin su dualismo, sin su don Quijote que se lanza contra la trama lógica del mundo, esta obra no aspiraba a tener una decoración estilística que pudiese continuarse por su propio valor. Como hemos visto, la progresión narrativa dependía por completo de la cómica oposición entre don Quijote y el mundo; el complejo de valores estáticos de Avellaneda no tenía ciertamente gran ímpetu narrativo. Y sin embargo, hay indicios de un futuro rococó en el barroco de Avellaneda. Tomemos como ejemplo el siguiente pasaje, en que el hábil secretario que había hecho de Tajayunques dice a su amo:

- Antes es de importancia que demos orden, si a vuestra merced le parece, que pieça tan singular y que es tan de rey, entre por nuestra industria en la corte para regocijarla; y eso habemos de procurar todos.

- No holgaría yo poco, dixo don Álvaro de que él allá llegase, como fuese yendo por diferente camino, y no con nosotros, sino de suerte que hiziese el viage a su modo con Sancho, de manera que cuando llegásemos allá, o dentro de breves días, topásemos con él para darle a conozer.

-Traça se me ofrece a mí luego, dixo el secretario..., y para efectuarla, déxeme vuestra merced disfraçar y poner en trage de negro... ${ }^{47}$

Aquí un astuto personaje se disfraza a fin de poder manejar 47 Ibid., pág. 103. 
en provecho propio la lógica de causa y efecto. La habilidad de disimular, de fingir con cierta intención, y no perversamente, como lo hace don Quijote, se convierte en nueva fuente de acción. El hombre listo podía lograr lo que don Quijote no lograba y, como recomendaba Gracián, sobrepujar en astucia al ciego e inflexible mecanismo del mundo. La novela que había de fundarse sobre esta base fue, claro está, la novela de intrigas, la llamada novela "novelesca" 48 .

A diferencia del Quijote apócrifo o del Guzmán de Alfarache, la novela de intrigas no intentaba por lo común reflejar los valores o la actitud ante la vida de su autor, sino que retrataba la organización social y racional del mudo en cuanto condición, en cuanto postulado del que debía partir la acción. Es decir, que, según nuestra definición, no eran plenamente novelas. Del mismo modo, en el rococó la decoración fue simple condición del arte, y no reflejo de una necesidad humana más profunda; fue una condición que sólo pedía intrigas de curva elaborada y superficial. Uno de los primeros ejemplos de este tipo de novela es El español Gerardo (1615-1617) de Céspedes y Meneses, basada en continuos disfraces e intrigas. Como muchas otras obras de la época, ésta se escribió sólo para divertir al lector ordinario y, por eso, la intriga, los inesperados sucesos, se efectuaban en un único plano. Con todo, su mundo es en muchos sentidos idéntico al de don Álvaro y don Carlos, al mundo del Quijote apócrifo. Si en Avellaneda

48 Con esto no quiere decirse que existía una relación física entre las dos formas, que el Quijote apócrifo puede ser fuente de alguna novela. Lo único que tratamos de demostrar es que la obra de Avellaneda revela, quizás mejor que ninguna otra, la esencia de ese mundo de la novela de intrigas, precisamente porque aquí se le da un tratamiento novelístico en términos de valor personal. Avellaneda así nos puede servir de medio para la comprensión literaria. 
la visión y los valores - que son la savia de la novela - habían quedado explícitos, en Céspedes y Meneses estaban implícitos y muy por debajo del plano de la acción.

En Francia, una novela como Francion (1623) de Sorel nos proporciona otro término de comparación. Además de su designación de "historia cómica", tiene otras semejanzas con el Quijote apócrifo: la burla contra los rústicos, el complacerse en los monólogos cómicos, cierta tendencia a los detalles escabrosos. En la medida en que Sorel intenta ridiculizar cuanto es "inverosímil", se acerca a la concepción que Avellaneda tenía del dualismo. Pero, a pesar de las frecuentes imitaciones de cuentos españoles, el autor francés carece de un don Quijote que le sirva de antivalor. El curso de su narración se basa en amor e intrigas, intrigas que consisten en un constante disfrazarse de las intenciones o de los personajes. Impedida por la intriga, la posible novela no llega a desarrollarse y el Francion puede definirse como una especie de punto intermedio entre Avellaneda y la verdadera novela de intrigas. Avellaneda, situado en las encrucijadas del barroco, demuestra, pues, a las claras, la formación de un tipo de novela que más tarde había de surgir en un abate Prevost o en un Walter Scott, y convertirse en el gran género europeo del siglo xIx. Pero para ello la novela había de superar la intriga en un solo plano y volver a los principios fundamentales del género, tal como los había establecido Cervantes. El Quijote apócrifo es, pues, el primer paso en la decadencia en que se sumiría la novela durante dos siglos, el primer paso, y el más largo, de alejamiento del Quijote.

Por consiguiente, la geografía literaria del Quijote apócrifo puede determinarse de acuerdo con los cuatro puntos indispensables de orientación. Detrás de la obra está la campaña por inculcar el pensamiento contrarreformista. Paralelos a ella se ha- 
llan los extraños estilos del barroco, que dan nueva expresión a la enseñanza ascética desde un punto de partida opuesto. Frente a ella se extiende la extensa llanura de la novela de intrigas, que es su derivación rococó. Por último, y alejado dimensionalmente de todos estos estilos, el Quijote original está en su propio plano. Se le ligó con su continuación sólo por la posibilidad de novelar que presentaba. El Quijote apócrifo es a la vez el otro lado del tapiz barroco y una caricatura, no de Cervantes, sino de la monumental invención cervantina: el género novela. 



\section{V \\ LA FORTUNA DEL QUIJOTE APÓCRIFO}

Una vez terminada la reconstrucción crítica del Quijote apócrifo sería quizás interesante hablar, para concluir, de su fortuna estética, del papel que ha desempeñado en la tradición literaria europea. Era inevitable, puesto que se trataba de una pobre imitación de Cervantes, que la mayor parte de sus lectores lo relegaran a la categoría de curiosidad literaria y no se ocuparan de él sino en la medida en que había influido en la auténtica Segunda parte. Sería inútil contradecir esta opinión; y sin embargo, hay en el Quijote apócrifo, a la vez que una imitación poco escrupulosa, algo que es independiente de Cervantes y que ha dado lugar a veces a juicios críticos igualmente independientes. Estos momentos de fragmentaria apreciación del valor autónomo de la obra son dignos siquiera de breve examen y explicación.

Como ya hemos observado, el Quijote apócrifo tiene cierta coherencia novelística, resultado del "opuesto humor" y de los valores y esencia creadora de su autor. Aunque le hubiera encantado el éxito, aunque llegó a decir que intentaba escribir un best seller, Avellaneda parece incapaz de crear en términos de los lugares comunes literarios de su época. En cambio llena su novela de sí mismo; él podrá ser - y con razón - anónimo, pero no es un don nadie. La novela rococó, o novela barroca popularizada, podía explotar la intriga complicada, el engaño a los ojos, el disfraz, el terrible castigo del cielo, a fin de atraerse y sostener la atención del lector, pero el Quijote apócrifo no 
era de este tipo. Ya sea por falta de talento, ya por intención, Avellaneda da a su obra unidad y expresividad. Su visión y sus valores hallan representación justa; en otras palabras, existe una relación artística adecuada entre la obra y su autor. Si esta adecuación puede considerarse quizás un primer requisito de todo valor estético, el segundo sería, en este caso, más difícil de demostrar. Habría que determinar si la adecuación en el Quijote apócrifo es significativa.

Los anónimos comentaristas franceses de la traducción de Lesage $^{1}$ y los neoclasicistas españoles Blas Nasarre y Montiano ya percibieron, según parece, la unidad de la obra. Opinaban ellos que la continuación era más "natural” y estaba más de acuerdo con la regla de la "verosimilitud" que el original. De hecho, el Quijote apócrifo es fiel a sus propios principios; jamás sale de las categorías narrativas impuestas desde el principio. Sancho y don Quijote son al final de la obra idénticos a como eran al principio, sólo que el tipo de cada uno se ha concretado más. El uno se hace más simple y el otro más grotesco y extravagante. Asimismo, el mundo que los rodea cambia de aspecto, pero no de esencia; va pasando de la sociedad rústica de Argamasilla del principio a la más alta sociedad cortesana del final, pero la presentación es siempre la misma. El Quijote apócrifo es una serie de cuadros, pintados para mostrar a don Quijote en un máximo de variedad con respecto al mundo que lo rodea. A medida que avanza la narración y un cuadro va sucediendo al otro, el desacuerdo entre los dos extremos va aumentando en proporción directa. Hay, pues, unidad en la construcción y unidad en el desarrollo del personaje. El sistema de valores cuya negación es don Quijote rechaza el desarrollo de la personalidad y también el empleo cervantino de diversos planos de

1 Véase el Journal des Sçavans, Paris, 1704, págs. 326-328. 
realidad; por eso el Quijote apócrifo es siempre verosímil, fiel a su concepción original.

No fue, pues, casualidad que esos críticos neoclásicos prefirieran la versión de Avellaneda. Esto no quiere decir que Avellaneda supiera algo de las "reglas"; como hemos visto, apenas consideraba su libro como obra de arte. Pero estas "reglas" correspondían, en la literatura francesa, a la estructura social de la Francia del siglo XVIII, estructura que estaba basada en los valores estáticos de la monarquía, la élite y la Iglesia. En la medida en que el neoclasicismo quiso apoyar el arte en reglas generales, y por tanto sociales, rechazando la inspiración individual, estaba de acuerdo con la actitud de Avellaneda ante la vida. Eso explica posiblemente la preferencia por el Quijote apócrifo. Por otro lado, hay que observar que la obra no es nada bienséante, que lo es mucho menos que el original. Es precisamente la historia de la negación de esa cualidad en don Quijote. El continuo contraste inherente al barroco y además la variedad de criterios nacionales de "buen gusto" - no era lo mismo para Avellaneda que para los franceses - se unieron a fin de expulsar toda bienséance.

Si el neoclasicismo gustó de la unidad del Quijote apócrifo, en el siglo xix Menéndez y Pelayo se dio cuenta, al parecer, de su coherencia. Hace notar el gran "realismo" del libro, su presentación auténtica de un mundo novelístico. Entre sus observaciones, casi todas desfavorables, se encuentra una comparación que a primera vista parece absurda:

Y sirve además para otra enseñanza estética, de carácter más general, es a saber, para mostrar práctica y experimentalmente la diferencia profunda que media entre el grande y humano realismo de un Cervantes o de un Shakespeare (por ejemplo) y el "naturalismo" de muchos franceses modernos, en cuyas filas se 
hubiera alistado con gran entusiasmo el falso Avellaneda, si hubiese llegado a conocerlos. La terre de Zola, por ejemplo, y este Quijote apócrifo parecen libros de la misma familia².

Parece, sin embargo, que Menéndez y Pelayo llegó a percibir, si bien no a explicar, un parecido realmente existente. La falta de selección en los detalles de la acción y de las circunstancias, que salta a la vista en toda la obra de Avellaneda, se asemeja bastante a los desbordados apuntes de los "naturalistas" más recalcitrantes, aunque en el Quijote apócrifo no hay trazas de ese don de transmisión poética que tenía Zola. Hay además cierto parecido entre los métodos de construcción novelística de Avellaneda y los de una obra como Nana. Los dos libros describen una serie de escenas que se van haciendo más extrañas y tensas a medida que avanza la acción. También aquí las semejanzas se explican por una razón fundamental: ambos autores se basan en una interpretación de la vida humana y su sentido que está fuera del individuo. Zola cree en la fatalidad de su pseudociencia (y aquí es donde se muestra más ingenuo), y Avellaneda se identifica con la ineludible ortodoxia escolástico-social de su época. Cada uno se adhiere a un sistema fatal, y al reflejarlo y sostenerlo van surgiendo semejanzas literarias de estructura y estilo y también una visión pesimista del mundo y del individuo que en él vive. En otras palabras, el crear partiendo de un punto de vista externo al individuo llega a hacer de éste un antihéroe, como lo son el falso don Quijote y Nana. La estructura narrativa está, pues, basada en el relato de su vida. Hay, por supuesto, innumerables diferencias: Avellaneda es prosaico, mientras Zola lo es sólo ocasionalmente; Avellaneda aspira a hacer comedia, Zola tragedia, etc. Pero es

2 Introducción al Quijote apócrifo, Barcelona, 1905, pág. xvi. 
innegable la semejanza entre las unidades de valor y estructura de las dos novelas, semejanza que confirma nuestra idea de la coherencia del Quijote apócrifo.

Si todo esto es verdad, si el Quijote apócrifo es único en su relación con el autor y uniforme en la presentación, ¿por qué fue tan poco popular en su tiempo y en épocas posteriores? El solo hecho de la imitación no es respuesta suficiente. No se ha dejado de admirar a la Celestina, a pesar de que se la cree obra de dos autores. La traducción revisada de Lesage dio al Quijote apócrifo breve fama en el siglo XVIII; Menéndez y Pelayo y ciertos otros críticos del siglo de la novela (Anatole France entre ellos) no lo condenaron del todo; pero en general se le ha relegado al mero campo de la erudición. No es difícil hallar la respuesta. Como ya hemos hecho notar, los artistas son frecuentemente disidentes; los valores creadores expresan su oposición a los esquemas aceptados. O, si no hacen esto, entretienen al público adaptándose a su gusto, y la significación primordial de su arte se basa entonces en la confianza de que ese gusto es acertado. Avellaneda no siguió ninguna de estas dos alternativas. Ciertamente no era disidente, y además, los valores que expresaba con tanta coherencia no por ello gustaban al lector de su época. La presentación directa y personal de estos valores e ideas debe haber parecido ingenuo lugar común a un público acostumbrado a verlos transfigurados en la poesía dramática de las comedias. La visión del mundo que expresaba no era tal que adquiriese interés por la ingenuidad de la presentación. Los esfuerzos de Avellaneda por entretener adolecían del mismo defecto. Como comediantes, don Quijote y Sancho estaban más hechos para los aristócratas ingenuamente perversos de la novela que para el público general que la leía; éste prefería un imprevisible mecanismo de engaños, intrigas 
y sorpresas a los largos monólogos que tanto divertían a don Álvaro y a don Carlos. Para su época la relación de Avellaneda con el Quijote apócrifo, si bien auténtica, era insignificante. No parece haber señal alguna de que fuera popular en el siglo XVII.

A partir de entonces, lo que ha dificultado la difusión del Quijote apócrifo es lo repulsivo de los pasajes pornográficos y sádicos, y más aún, la desaparición de esa visión de la vida en que se apoyaba ${ }^{3}$. Como ya observábamos una vez, Avellaneda no expuso la significación de la existencia humana en cuanto problema en tal forma que su creación pudiese ser válida para los siglos venideros y sobrepasar las fronteras nacionales. Por lo contrario, decidió defender una única solución, una solución rígida en su dogmatismo y definición; y con el fracaso de ella, fracasó el libro. Desde el punto de vista de la supervivencia, la obra es necesariamente insignificante. Tiene sin embargo cierto valor, y no es del todo imposible imaginar un futuro en que las circunstancias humanas den nueva vida al Quijote apócrifo. Si no universal, es al menos auténtico.

3 Es curioso observar, a este respecto, que hoy día en España se están vendiendo y exhibiendo varias ediciones populares de la obra. 


\section{APÉNDICE \\ AVELLANEDA Y LA AUTÉNTICA SEGUNDA PARTE}

En el capítulo segundo hablábamos de las semejanzas que hay entre el Quijote apócrifo y la Primera parte del original. Existen también, como afirmábamos entonces, ciertos paralelos extraños entre las dos Segundas partes, paralelos que han dado lugar a que algunos críticos, entre ellos Menéndez Pidal, digan que si Avellaneda imitó a Cervantes, Cervantes también imitó a Avellaneda. El peso de esta acusación nos obliga a inquirir en el asunto cuidadosamente. Hay en general dos tipos de semejanzas entre las dos Segundas partes: en primer lugar, en unos cuantos casos, la igualdad casi literal de unos pasajes, y en segundo lugar una presentación semejante de sucesos. Ambos parecen probar que entre las dos partes existe una relación que hasta ahora no se ha advertido. Cervantes no da señales de conocer la obra rival hasta el capítulo LIX de la Segunda parte; por otro lado, aunque en el prólogo de Avellaneda hay una alusión a la continuación de Cervantes, es una alusión muy vaga que da la impresión de que Avellaneda no la conocía de cerca.

Veamos primero algunas semejanzas literales:

Avellaneda

...nos están aguardando con una muy gentil olla de vaca, tocino, carneros, nabos y berças,
Cervantes

Señor huésped, dijo el ventero, lo que real y verdaderamente tengo son dos uñas de 
que están diziendo: cómeme, cómeme (cap. IV, pág. 37). vaca que parecen manos de ternera, o dos manos de ternera que parecen uñas de vaca: están cocidas con sus garbanzos, cebollas y tocino, y la hora de ahora están diciendo: "¡cómeme!” “¡cómeme!” (II, LIX).

[Sancho ha estado comiendo albondiguillas en el banquete de don Carlos; también ha comido cuatro de las] seis pellas de manjar blanco... las otras dos que dél le quedaban se las metió en el seno con intención de guardarlas para la mañana (cap. XII, pág. 93).
Acá tenemos noticia, buen Sancho, que sois tan amigo de manjar blanco y de albondiguillas, que si os sobran, las guardáis en el seno para el otro día (II, LXII).

Estos paralelos los reunió Martin Wolf, quien, por apoyar su teoría de la imitación a la inversa, no completa la segunda cita de Cervantes. Sancho responde a la acusación negando esa glotonería:

...quienquiera que hubiere dicho que yo soy comedor aventajado y no limpio, téngase por dicho que no acierta; y de otra manera dijera esto si no mirara a las barbas honradas que están a la mesa ${ }^{1}$.

Es esto alusión evidente a la calumnia de Avellaneda. Ambos ejemplos y otro sin importancia que señala Wolf están después del capítulo en que Cervantes menciona por primera vez la obra de Avellaneda; si en ellos imita a su rival es sólo para re-

1 Quijote, II, LXII. 
futarlo. El hecho de que Cervantes copie dos o tres frases de Avellaneda no es digno de comentario especial; lo único que cabría decir es que nos muestra que Cervantes se había tomado el trabajo de leer con cierto cuidado el Quijote apócrifo y que su crítica no era arbitraria ni ciega. Lo importante es el hecho de que no se encuentran semejanzas como éstas antes del lugar en que Cervantes declara oficialmente conocer la otra obra. De esto se deduciría que estaba diciendo la verdad.

Pero las semejanzas entre ciertos sucesos presentan un problema mucho más grave. Estos sucesos son: el combate de los caballeros (la lucha que sostiene el Sancho de Cervantes con Tomé Cecial se asemeja mucho a la lucha del de Avellaneda con el caballero negro del gigante Tajayunques); el engaño que sufre don Quijote al presenciar una representación teatral (la comedia de títeres de Ginés de Pasamonte en un caso y El testimonio vengado de Lope en el otro); y, por último, el recibimiento que se hace a uno de los Quijotes en el palacio de los duques y al otro en la residencia del "Archipámpano". Todo el ambiente de complicadas burlas y trucos que los ociosos y aburridos aristócratas hacen a don Quijote y Sancho está en las dos obras y presenta gran número de sorprendentes paralelos. En ambas, por ejemplo, escribe Sancho una carta a su mujer, contándole su buena suerte, y en ambas hay divertidas escenas de banquete construidas a base del contraste entre los ilustres comensales y la extraña pareja. Es interesante observar, sin embargo, que en ninguno de los sucesos paralelos se ven semejanzas literales².

Hay tres maneras posibles de explicar estas coincidencias:

2 Excepción secundaria a esta afirmación es el hecho de que en las cartas de los dos Sanchos la duquesa y la Archipampesa besan la mano, respectivamente, a Teresa Panza y a Mari Gutiérrez. 
Cervantes puede haber tomado elementos de Avellaneda, a pesar de que sólo a partir del capítulo LIX afirma conocerlo; Avellaneda puede haber copiado de Cervantes; por último, las semejanzas pueden haber surgido simultáneamente y por separado, al desarrollar los dos autores las posibilidades narrativas lógicas del esquema don Quijote-Sancho. Tanto Menéndez Pidal como Martin Wolf adoptan la primera explicación. Menéndez Pidal asegura que el Quijote apócrifo fue, si no otra cosa, al menos fuente de inspiración "por contraste". Y explica con estas palabras el hecho de que Cervantes posponga la primera mención de Avellaneda hasta el capítulo LIX:

Puede sospecharse que el Quijote de Avellaneda circulaba en manuscrito, como tantas obras entonces, y que Cervantes tuvo de él conocimiento desde que empezó a componer su Segunda Parte... Avellaneda, al imprimir su obra, añadiría el prólogo agresivo, el cual, al ser leído por Cervantes, halló repulsa en el capítulo LIX del verdadero Quijote ${ }^{3}$.

Esto parece muy posible, pero ¿por qué es tan necesario suponer que Cervantes plagió a Avellaneda? La razón que aduce Martín Wolf parece enteramente infundada. Wolf no examina ni el tipo ni el lugar de la imitación, y llega a la conclusión de que, como Cervantes tomó seguramente palabras de Avellaneda después del capítulo LIX, debió copiar también las situaciones paralelas que hay antes de dicho capítulo. El hecho mismo de que las semejanzas concretas comiencen inmediatamente después de la primera mención de la obra de Avellaneda y de que no las haya en absoluto antes de ella no favorece en nada a esa teoría. Si Cervantes hubiera poseído un ejemplar del Qui-

3 Ramón Menéndez Pidal, Un aspecto en la elaboración del "Quijote", Madrid, 1924, pág. 64, n. 1. 
jote apócrifo mientras escribía la Segunda parte, ¿no habría más semejanzas literales a lo largo del libro? No es nada probable que Cervantes las incluyera conscientemente, con la intención de despistar a los críticos del futuro o de probar su tardío conocimiento de Avellaneda. Lo probable es que no conociera la falsa Segunda parte hasta que escribió el capítulo LIX.

De ahí que las semejanzas de sucesos y ambientes que hay antes de este capítulo de Cervantes y en todo el libro de Avellaneda deban explicarse como imitación por parte de Avellaneda o como coincidencia. La segunda suposición parece la más improbable (aunque no imposible) dado el número de semejanzas. Las posibilidades de desarrollo del tema don Quijote-Sancho no parecen ser tan limitadas que cada autor, por su lado, debiera llegar inevitablemente a muchas situaciones idénticas. La única explicación que nos queda es aquella que a primera vista da la impresión de ser la más dudosa desde el punto de vista de la posibilidad física, aunque es a la vez la más atrayente para el cervantófilo. Es, claro está, que Avellaneda no sólo imitó la Primera parte del Quijote de Cervantes, sino también la Segunda. Uno de los principales obstáculos de esta hipótesis es la cuestión del tiempo. Las aprobaciones del Quijote apócrifo, fechadas la una el 18 de abril y la otra el 4 de julio de 1614, demuestran que Avellaneda había terminado la obra al comenzar la primavera de ese año y que Cervantes supo de ello quizás en septiembre, época en que estaba trabajando en el capítulo LIX.

Cervantes debió terminar la Segunda parte a principios de 1615, puesto que se publicó en otoño de ese año. Este cálculo aproximativo dejaría a Cervantes unos cuatro o cinco meses para terminar los últimos quince capítulos, es decir, poco más o menos una o dos semanas para cada capítulo. Si este ritmo de 
trabajo fue constante, implicaría que Cervantes escribió toda la Segunda parte en poco menos de dos años, y este lapso de tiempo hubiera dado a Avellaneda pocas posibilidades de conocerlo. Pero no debemos necesariamente apoyarnos en esa suposición. Parece haber un cambio definitivo de ritmo después del descubrimiento de la versión apócrifa. Es como si Cervantes se hubiera esforzado por impedir que la obra rival adquiriera carta de naturaleza en la mente del público y se realizaran con ello las esperanzas de Avellaneda. Cervantes debe haber necesitado dinero con urgencia, y además, como hemos visto, temía por su fama literaria y su significación como artista. La burla de la cabeza encantada, la reintroducción de personajes de esquema literario, como la pastora o Roque, el jefe de bandoleros, y la historia morisca interpolada podía haberlas escrito Cervantes rápidamente, puesto que eran en cierta medida repetición de cosas ya antes escritas. Carecen de la majestuosa secuencia de sucesos magníficos que caracteriza casi toda la Segunda parte, la cual debió escribirse lentamente, sustentada por toda la potencia creadora de su autor. Por supuesto, Cervantes recupera esa majestad en el retorno final, que es como una marcha fúnebre; pero no cabe duda de que después del capítulo LIX estaba tratando de terminar lo más pronto posible. Esto es, de suyo, demostración importante de que antes de ese capítulo no sabía nada de Avellaneda. Aun sin haber leído el insultante prólogo, lo habría inquietado y aguijado el conocimiento de la destructora reinterpretación que Avellaneda hacía de sus personajes; lo demuestra la reacción crítica del segundo prólogo. La proposición de Menéndez Pidal no explica este cambio en la progresión interna de la obra.

La rapidez, comprobable, con que se escribieron los últimos quince capítulos no se opone a la lentitud con que se com- 
puso el resto de la Segunda parte y que hallamos confirmada por Schevill:

...la segunda parte ocupó probablemente casi toda esta década (1605-1616): hay señales de que Cervantes se dedicó de nuevo al trabajo... en 1606 o 1607, y la dedicatoria de la obra ya completa al Conde de Lemos está fechada el último día de octubre de $1615^{4}$.

Fuera de esto, ya en 1613 Cervantes mismo pensaba que su trabajo iba muy adelantado, puesto que en el prólogo a las Novelas ejemplares dice:

Tras ellas, si la vida me deja, te ofrezco los Trabajos de Persiles... y primero verás, y con brevedad, dilatadas las hazañas de don Quijote, y donaires de Sancho Panza...

Analizando, pues, el tiempo, vemos que, aunque hubiese tardado dos años en la composición de su Quijote, Avellaneda tenía más que sobradas oportunidades de enterarse de lo que Cervantes estaba escribiendo. Además, es probable que el Quijote apócrifo se completara en poco tiempo, puesto que no es compleja su organización interior y sus personajes permanecen todos en un solo plano y actúan de acuerdo con su tipo. El proceso creador de Avellaneda debió haber consistido casi sólo en inventar situaciones y escribir el diálogo. El conocimiento de lo que Cervantes estaba haciendo no podía sino facilitar aun más este proceso.

Si los obstáculos de orden temporal distan de ser insalvables, queda aún el problema de cómo pudo Avellaneda imitar

4 Rudolf Schevilu, Cervantes, New York, 1919, pág. 250.

5 Prólogo a las Novelas ejemplares. 
a Cervantes. Al parecer, no tuvo en sus manos el manuscrito de la Segunda parte; de lo contrario es indudable que habría esas coincidencias verbales que hemos observado en las imitaciones de la Primera parte o del manuscrito del Buscón. No sólo esto: quizá hubiera aprovechado la auténtica Segunda parte mucho más de lo que lo hizo, y entonces no habría duda acerca de quién copió a quién. Pero la conexión puede explicarse con esta excelente observación de Fitzmaurice Kelly:

El parecido entre los dos puede comprenderse por la costumbre poco prudente que tenía Cervantes de leer a otros lo que había escrito, mucho tiempo antes de que estuviese listo para la imprenta $^{6}$.

Si Cervantes tenía realmente esta costumbre, parece del todo probable que, debido al gran interés de sus contemporáneos por el Quijote, circularan por todas partes rumores acerca de lo que estaba haciendo. De este modo, Avellaneda pudo haberse enterado lo bastante de ciertos incidentes de la obra para incorporarlos en su libro (tal como había incorporado la aventura de la venta). Esto explicaría a la vez el parecido general y la carencia de un paralelismo exacto 7 .

Podemos resumir del siguiente modo los argumentos que nos llevan a esa conclusión: Cervantes no sabía de la existencia del Quijote apócrifo antes de escribir el capítulo LIX de la Segunda parte, por tres razones: en primer lugar, lo dice él mismo, y no tenemos por qué ponerlo en duda; en segundo lugar, imita algunos rasgos del estilo de Avellaneda después del capítulo

6 J. Fitzmaurice Kelly, The life of Cervantes, London, 1892, pág. 142.

7 Compárese, por ejemplo, la rigurosa y detallada imitación de los acontecimientos de la venta con la reinterpretación absoluta del "retablo de Maese Pedro". 
LIX, pero no antes; en tercer lugar, después de ese capítulo se da prisa en terminar la obra, ocasionando un cambio en el ritmo y en los acontecimientos, perceptible a primera vista para todo lector sensible. Por ello, y rechazando para la mayor parte de los casos la posibilidad de una coincidencia ${ }^{8}$, Avellaneda tiene que haber imitado a Cervantes. Pero dado el carácter poco preciso de las semejanzas, es de suponerse que Avellaneda no tuvo conocimiento directo del original. Debió haberlo sabido de oídas.

Esta cadena de argumentos puede someterse a una prueba objetiva. Si son acertados, no debe haber coincidencia alguna entre el Quijote apócrifo y los capítulos inmediatamente anteriores al LIX de la auténtica Segunda parte. Cervantes escribió probablemente estos capítulos después de terminado el Quijote apócrifo y antes de su publicación. Cualquier semejanza en este lugar demostraría definitivamente que Cervantes poseía un manuscrito de la imitación. Por un lado, Cervantes no sabía

$8 \mathrm{El}$ uso paralelo de un proverbio, como el que veremos en seguida, podría fácilmente tomarse por coincidencia. Dice Sancho: “-¿Qué le parece, señor don Quixote, a vuestra merced? ¿Hanse de her desta manera las aventuras? ¿Parécele que les voy dando en el hito? -Paréçeme Sancho, dixo don Quixote, que el que se llega a los buenos ha de ser uno de ellos, y quien anda entre leones a bramar se enseña" (Quijote apócrifo, capítulo XIV, págs. 109-110). Esto recuerda la respuesta de Sancho al eclesiástico cuando éste le pregunta si es realmente Sancho Panza: “-Sí soy, respondió Sancho, y soy quien la merece tan bien como otro cualquiera; soy quien «júntate a los buenos, y serás uno de ellos»" (Quijote, II, XXXII). Si Avellaneda imitaba el proyecto de Sancho mencionado en la Primera parte, de hacerse caballero, proyecto que en la Segunda parte se transforma en "quijotización", nada más natural que use este proverbio tan común al referirse a ello. La relación entre los dos proviene de la Primera parte, y no es resultado de un contacto directo entre las Segundas partes. Respecto a la gran difusión de ese proverbio, véase E. DE CÁrCer y de Sobíes, Las frases del "Quijote", prólogo de Rodríguez Marín, Lérida y Barcelona, 1916. 
oficialmente de la existencia del Quijote apócrifo, y por otro, había concluido ya su obra. Pero, en efecto, no hay correspondencia alguna. El último paralelo directo que se ha hallado es el de la carta de Sancho a su mujer; Cervantes pone esta carta en el capítulo XXXVI de la Segunda parte, mientras que Avellaneda la coloca hacia el final de su versión, en el capítulo XXXV (son treinta y seis en total). Hay, pues, trece capítulos en Cervantes que no tienen paralelo temático en Avellaneda. Al menos algunos de ellos tienen que haberse escrito mientras se aprobaba e imprimía la versión apócrifa.

Como última confirmación de esta teoría es importante hacer notar que las semejanzas se encuentran a todo lo largo de la versión apócrifa y que en cambio terminan en la mitad de la auténtica. Es más que probable que Avellaneda haya imitado la Segunda parte de Cervantes lo mismo que la Primera. El plagio es cosa habitual. 